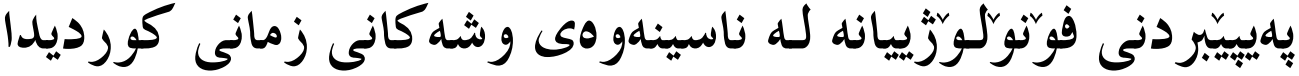

\section{Phonological Perspective in Recognizing Kurdish Language Word}

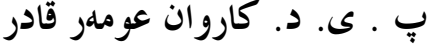

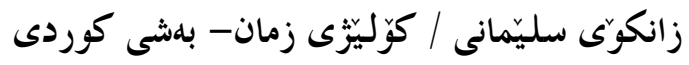 \\ Assist.Prof.Dr. Karwan Omer Qadir
}

University of Sulaimani/College of Langauges-Kurdish Dept.

E-mail: Karwan.qadir@univsul.edu.iq

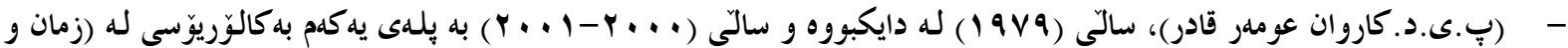

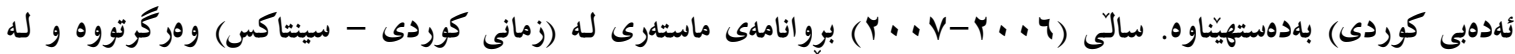

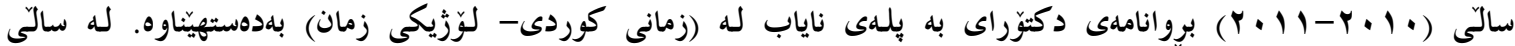

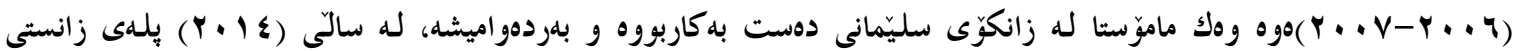

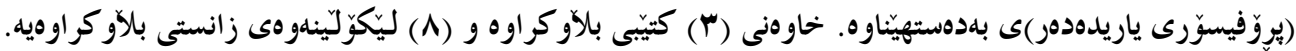

$$
\begin{aligned}
& \text { ب.ى.د. شاخلهوان جلال حاجى فهرهج } \\
& \text { زانكوّى سليّمانى / كوّليّزى زمان-بهشى كوردى }
\end{aligned}
$$

Assist.Prof.Dr. Shakhawan Jalal Haji Fraj

University of Sulaimani/College of Langauges-Kurdish Dept.

E-mail:Shakhawan.faraj@univsul.edu.iq

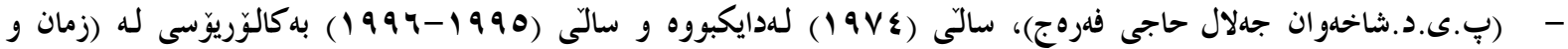

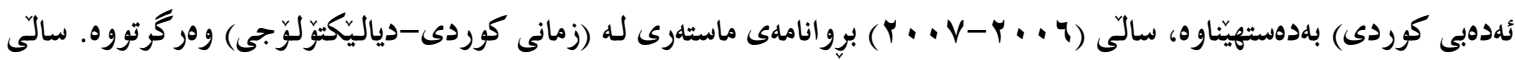

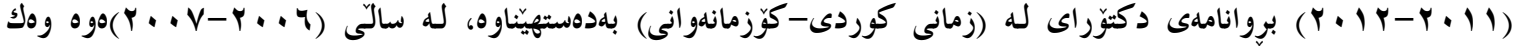

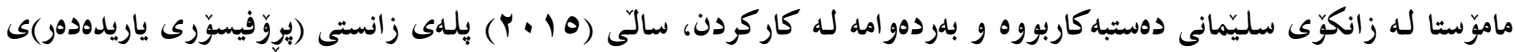

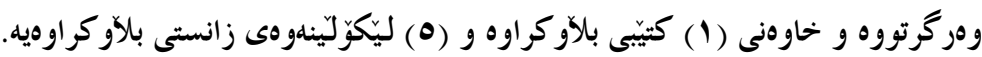

$$
\begin{aligned}
& \text { ب..ى.د. ئاثيّستا كهمال مdحمورد }
\end{aligned}
$$

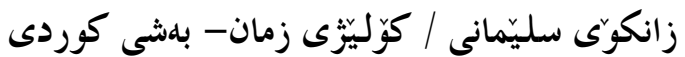

Assist.Prof.Dr. Avesta Kamal Mahmud

University of Sulaimani/College of Langauges-Kurdish Dept.

E-mail: Avesta.mahmud@univsul.edu.iq

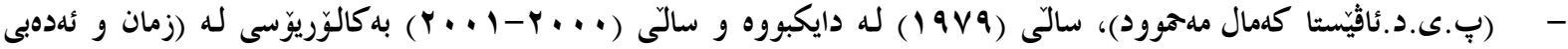

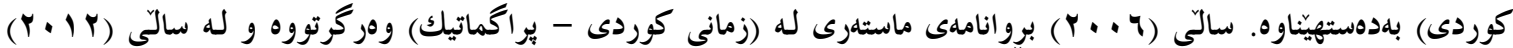

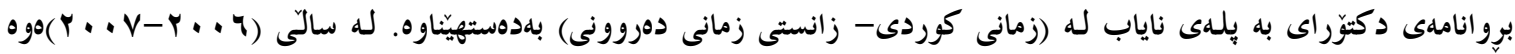

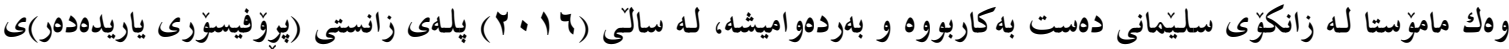

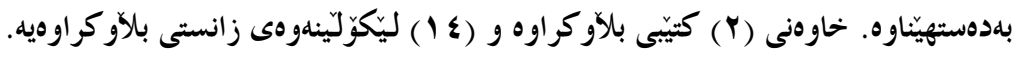




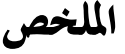

ان هذا البحث يتناول مفهوم و كيفية تعرُف المُككم المى السلسلات الصوتية (الفونولوجية) و ذالك في اطار النظرية الاثار (Trace Model)، و وأنَ هذا النظرية احدى اليات تبحث لدى اللغوين الذ ين يَعَلَمون بنظريات (التزابطية"Connectionist"). و مِن هذا المُطَلق قامَ هذا البَحث بِتَحليل سلسلات الكَلِماتْ ففي اللغة الكُردية و لزيادة كيفية الفَهم و التعرُف المى كيفية بِناء هذهِ التزاكيب قُمنا بُعقارنة كَلِمات في اللغة الكُردية مَعَ بُنية التزاكيبية لِلكَلِمات في اللغة الفارسية و ذالِك لِّتوصل المَ نَتائِج مرضية و علمية. و لِلتأكد مِن النتائج قامَ هذا البَحث بوضعْ فَرضيات كيفية بِناء التَراكيب الصوتية و تَباين مدى التَماثُل الفونولوجي بين اللغة الكردية و اللغة الفارسية و أساس هذا الفرضية يُرجع الى نظريات التي

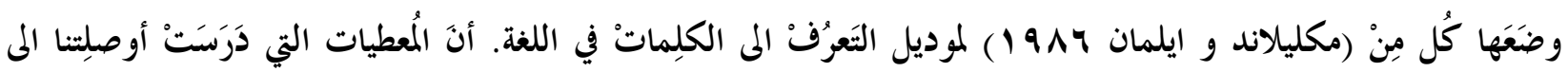
استنتاجْ أنَ ما أفزَضناهُ في الفرضية الآولى و ذالِك يدُلْ أنَ الفرضية البحث كانت ناجحة بِمعاير علمية في هذا البحث وأنَ التَماثُل التزاكيبي في اللغثين يُرجع المى تَماثُل الاثار في المقاطع الاساسية في الكلمات (الكردية و الفارسية) و الاختلِفات البارِة جاءت مِنْ خحلال التَمدُد التأريخي لِلكِلمات.

\section{Abstract}

This research is confers Speech Perception and a Phonological perspective in a frame of TRACE model in a Connectionist point of view and that's all to Analysis Kurdish and Persian language relatives. According to this view the research entitled (Speech perception and phonological Analysis in Word Recognition). In this research we assumes that Kurdish and Persian language have many similarity especially in phonological level, for reasoning this assumption and analyzing our data we use TRACE model which, developed by McClelland and Elman (1986), is speech recognition model similar to the interactive model of word recognition , and it is based on a connectionist approach in psycholinguistics.

The data that this research investigate drive us to serial Conclusion which are close to our first assumption (more relative between two language ) and every difference between two related languages should be explicable to a high degree of plausibility, and systematic changes by this the study declares historical relationships between the two languages and the synchronically difference. The research content a preface and a body which is divide to three sections and a conclusion: First section: it contents a review of Trace Model (concept and the principle) and the reason to work with this model and selecting it among all another models, because TRACE is based on a connectionist system. There are connections among units at three levels: features, phonemes and words and The TRACE model are thus consistent with the idea of competition among units in the lexicon. In other words, at given time.

Second section: in this section we achieve the TRACE model in Kurdish language, particularly in word cognition and phonological level because the models base on three basic levels: phonological Features, phonemes and word. Third section : we compare in this section both of the two languages(Kurdish and Persian ) through what we got from the results in the second section and this comparative lead us to three main results, like that the both languages have similar phonemic system with a rare different in phonemes feature. 


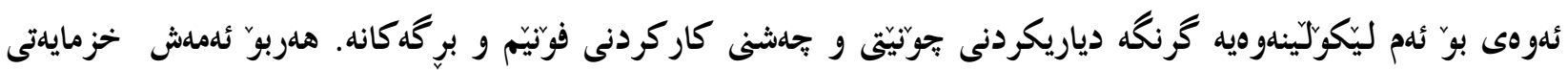

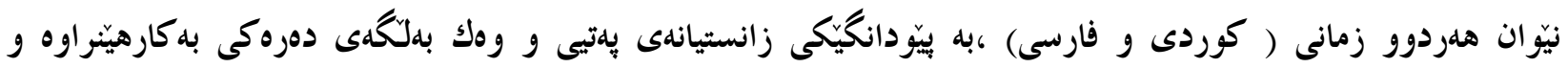

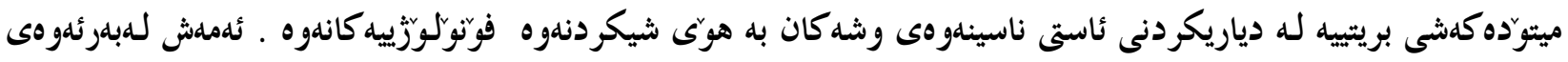

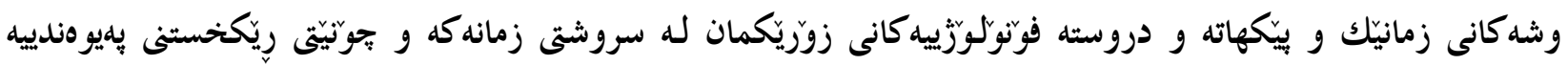

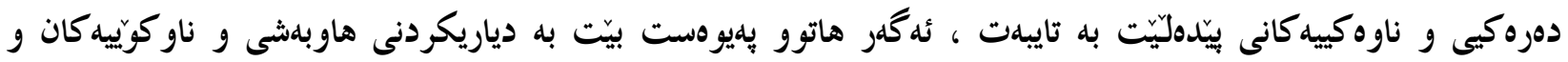

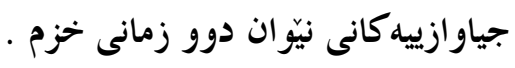

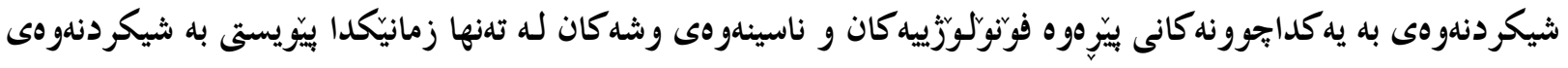

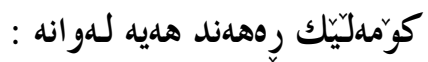

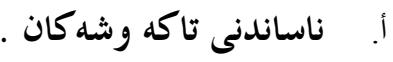

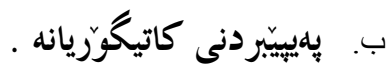

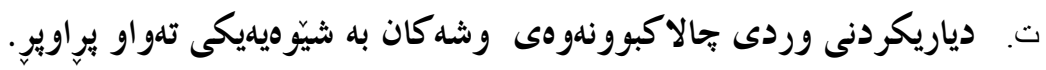

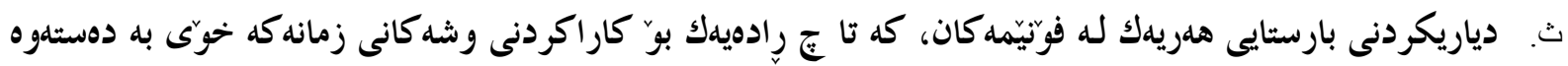
دهدات .

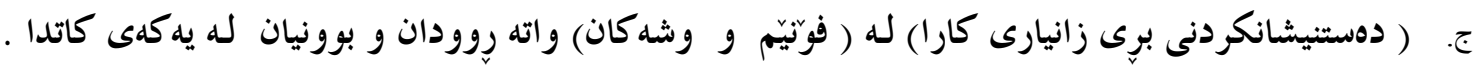

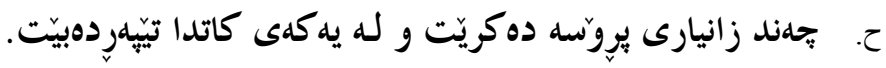

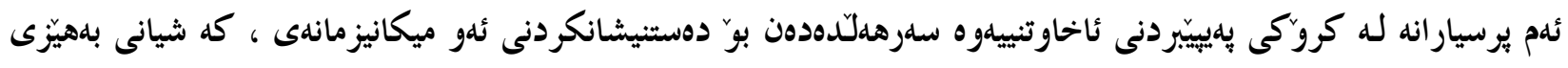

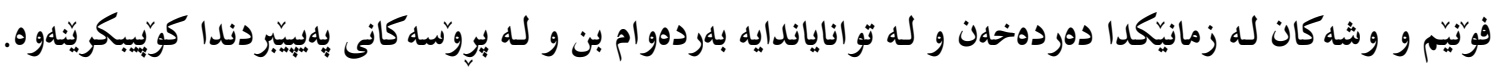

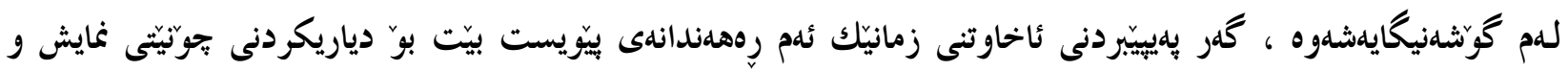

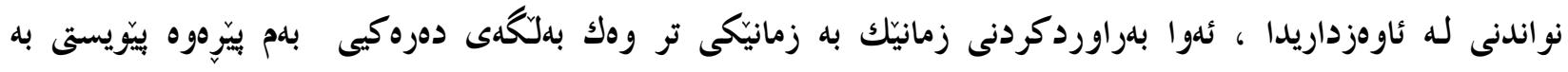

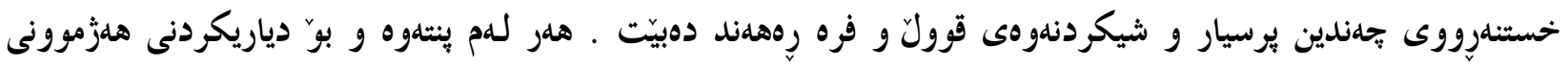

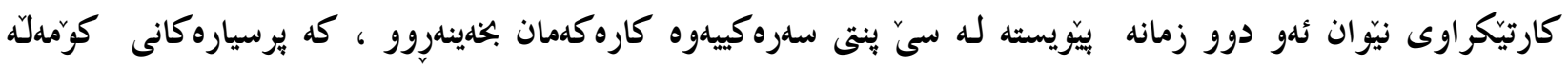

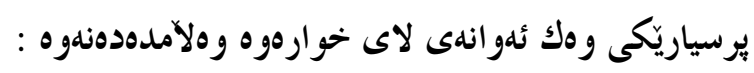

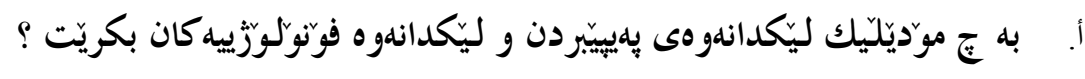

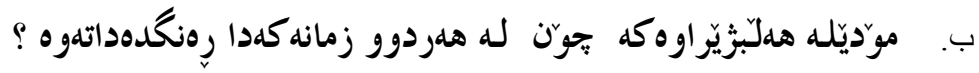

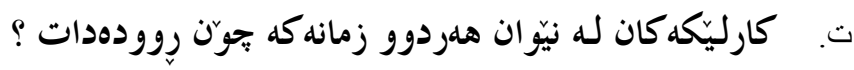

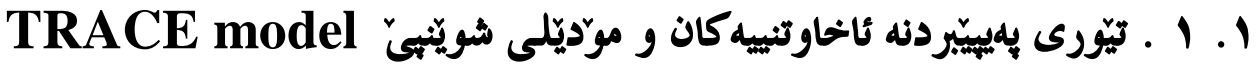

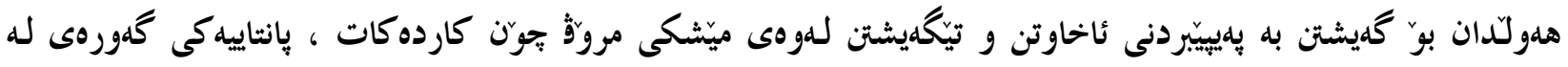

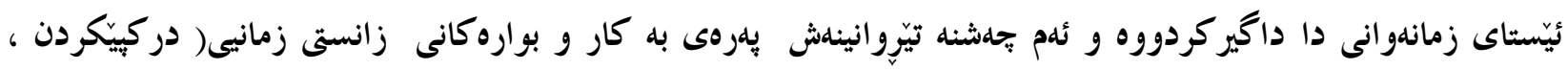

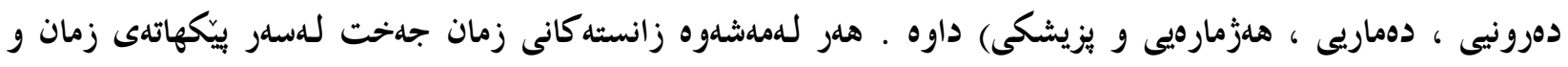




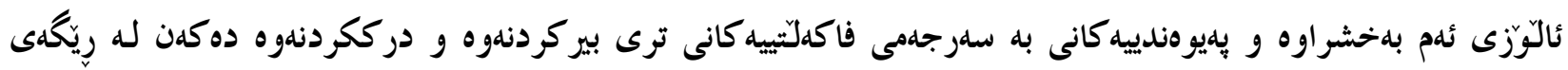

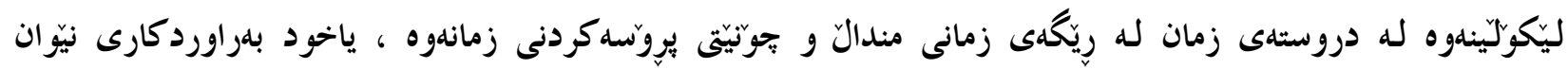

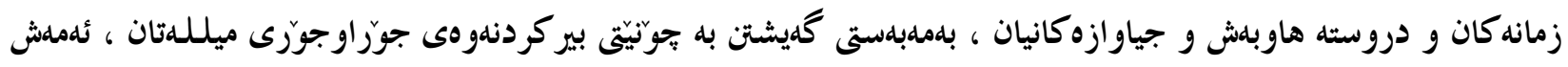

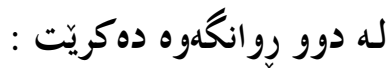
أ. روانكگى سينكروّنى ب. روإنكهى داياكروّيى

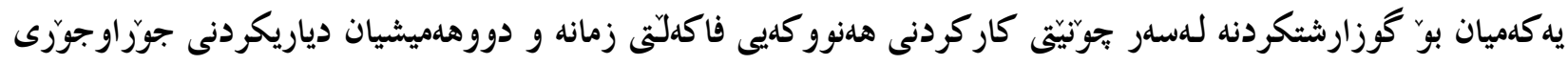

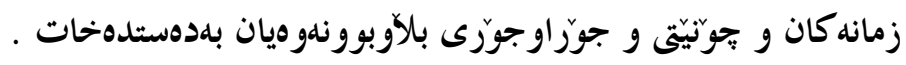

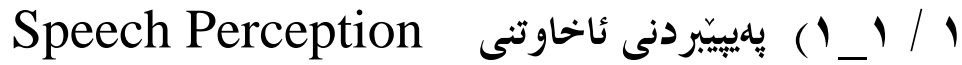

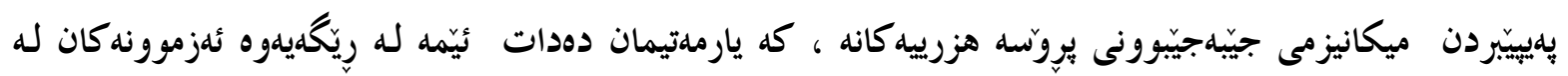

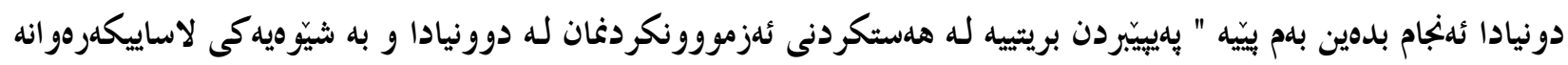

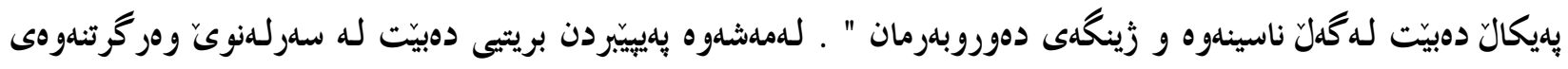

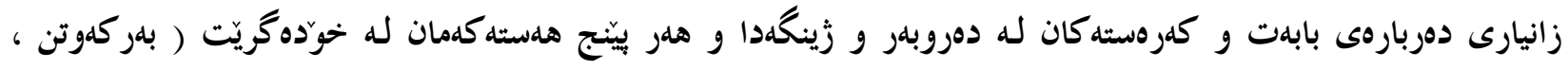

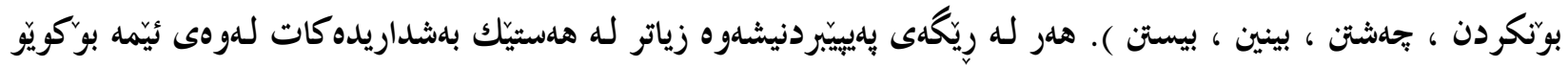

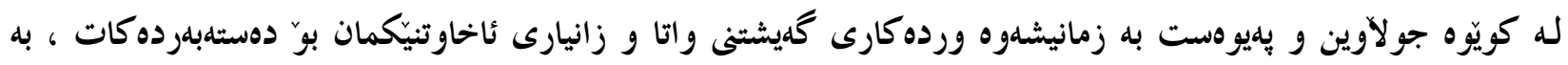

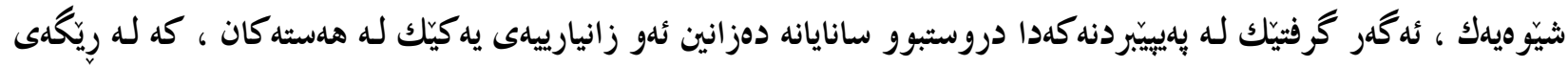

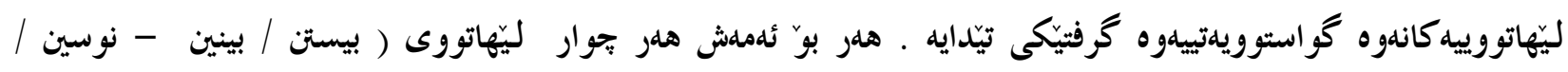

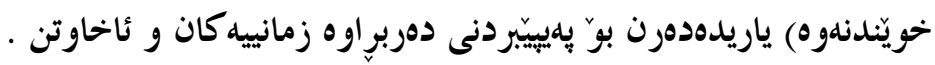

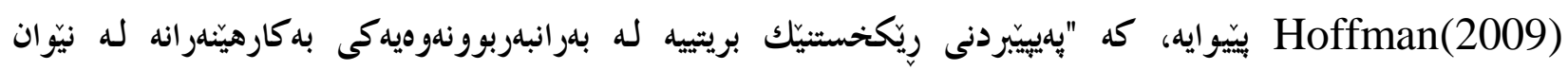
ريّكخر اوه كه و دونيايى بابهتيبووندا".

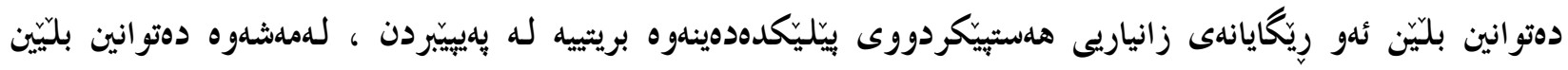

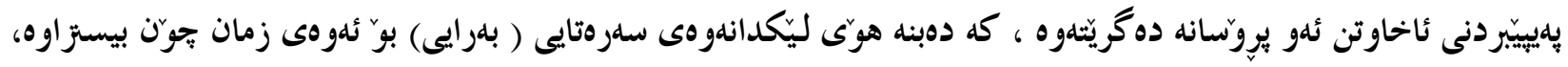

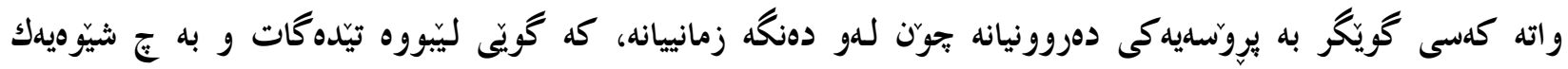

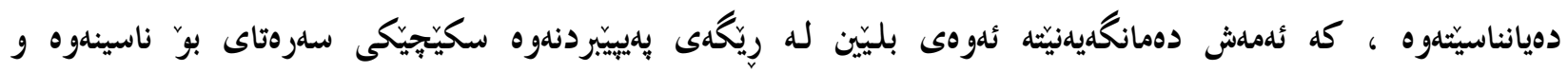

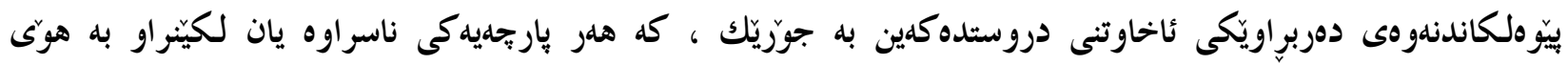

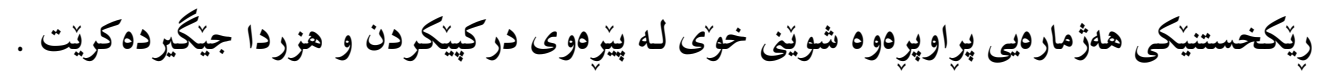

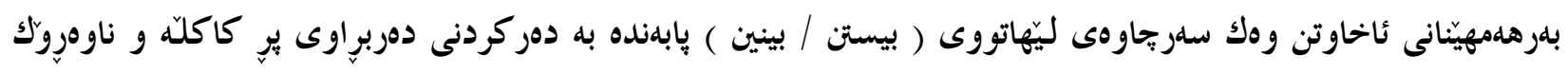

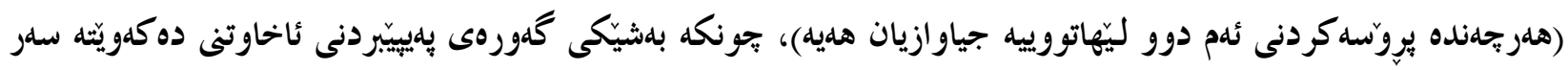

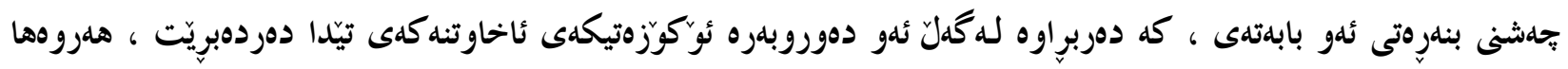




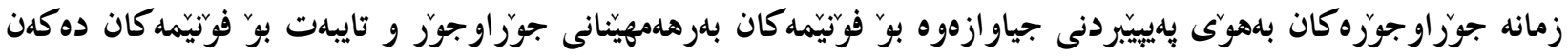
وهك ( كرتاندن و زيادكردن...هتد) ، كه ألهمش خحاسيلت و تايبلى زمانهكان دروستدهات للهسهر هلردوو ئاستى

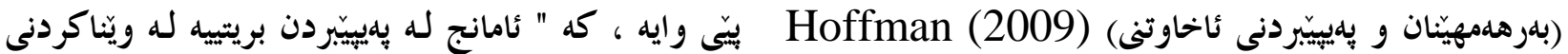

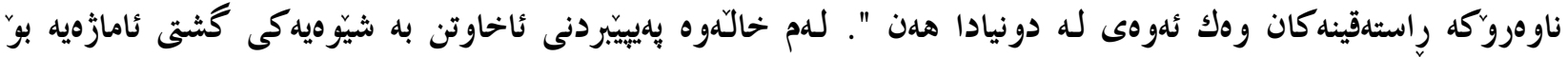

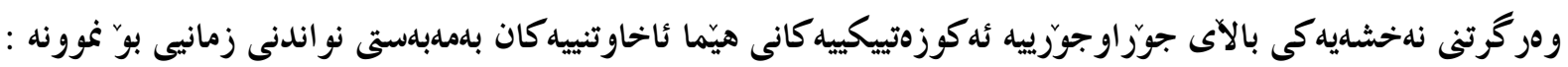

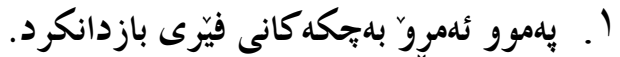

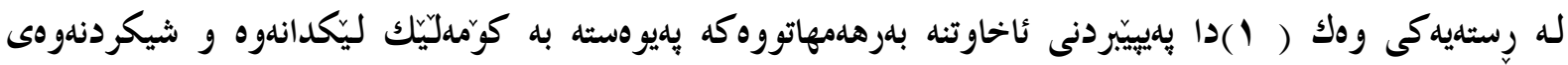

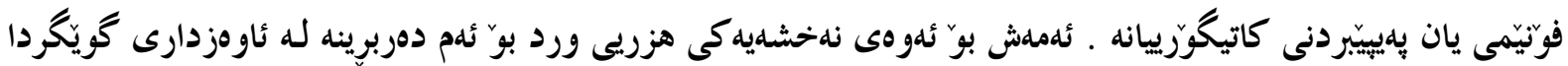

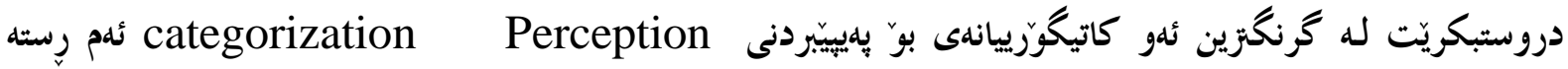

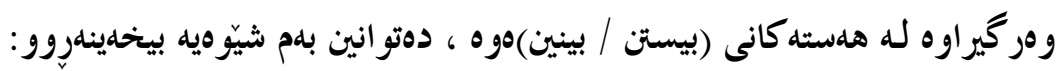

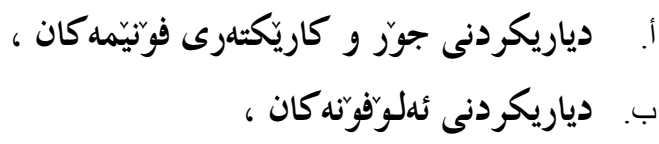

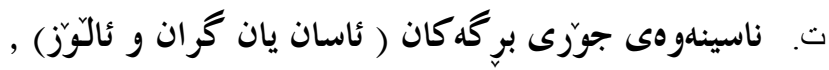

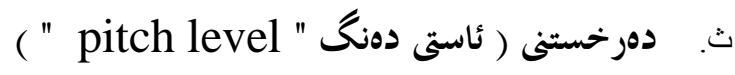

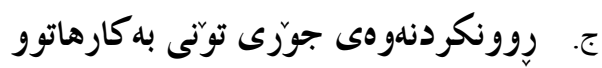

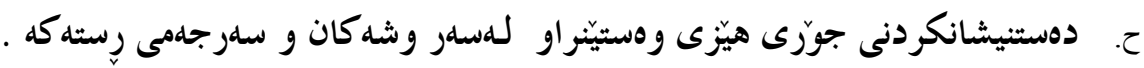

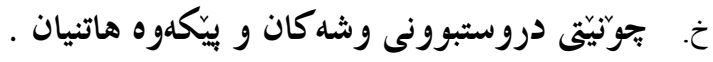

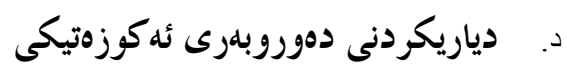

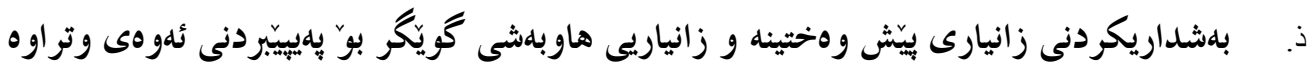

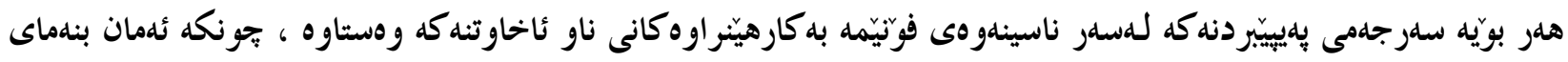

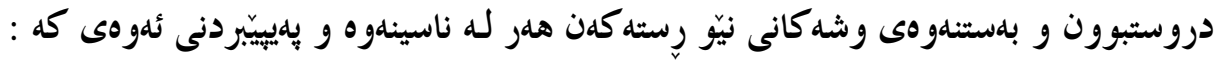

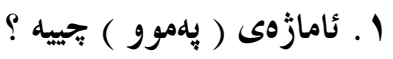

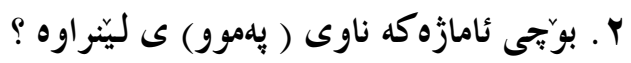

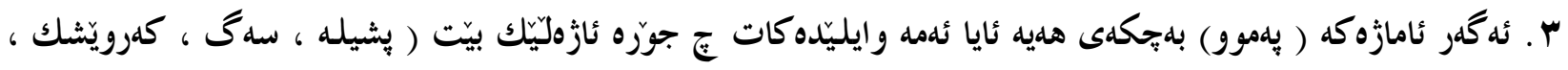

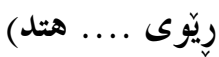

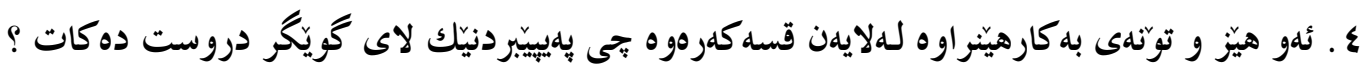

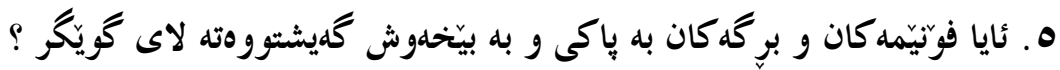

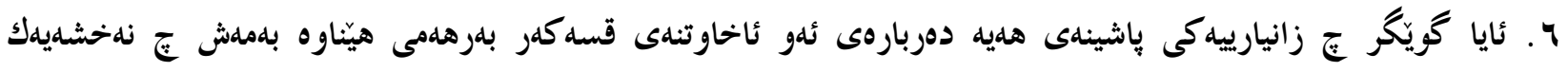
دروست دهبيّت؟

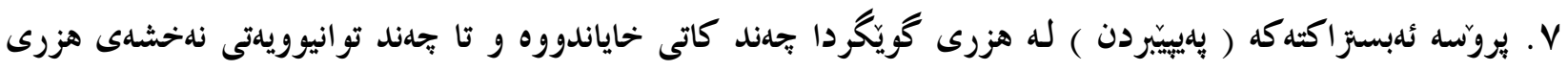
خوّى لله نهخشهى هزرى قسه كهر نزيكبكاتهوه. 


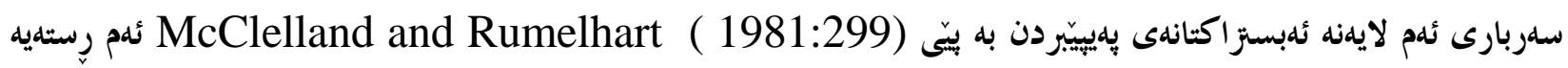

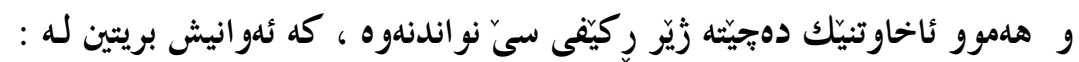

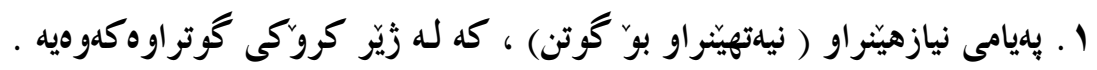

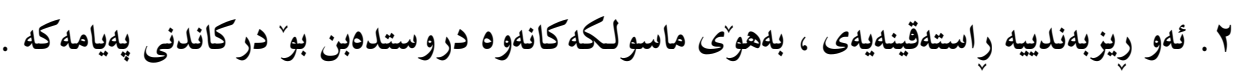

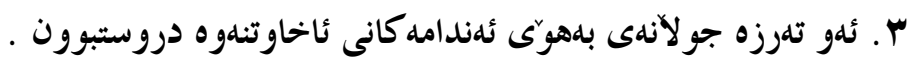

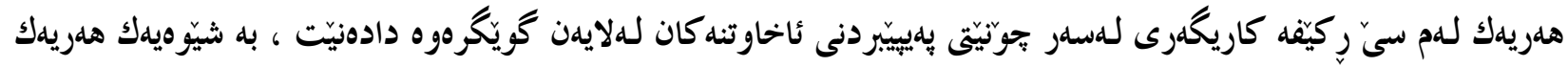

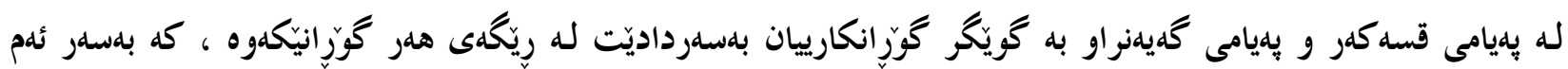

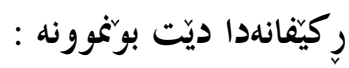

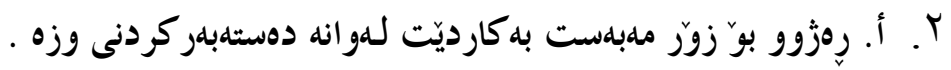

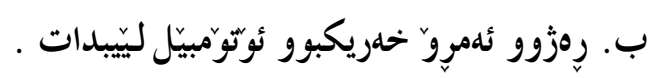

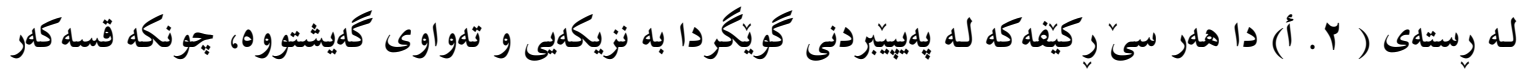

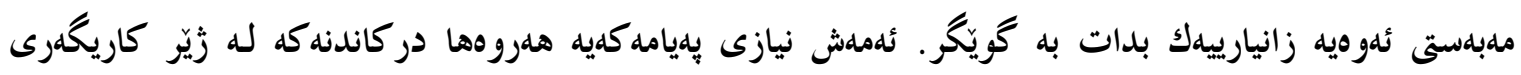

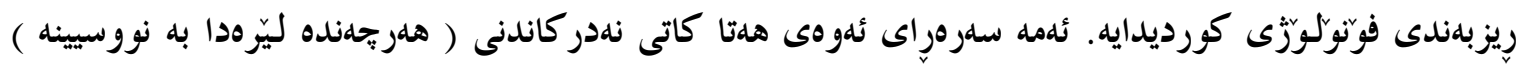

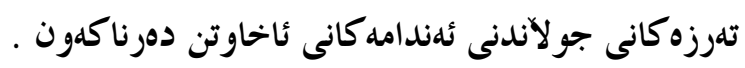

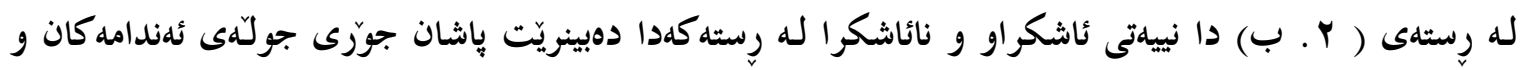

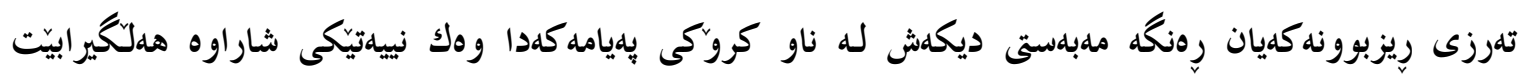

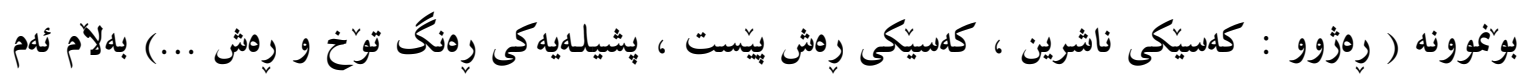

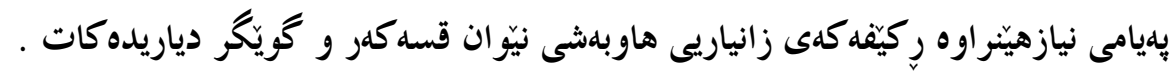

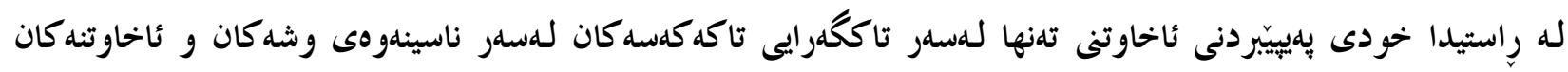

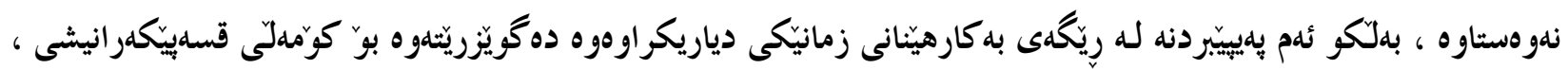

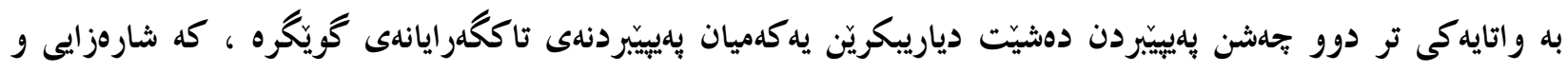

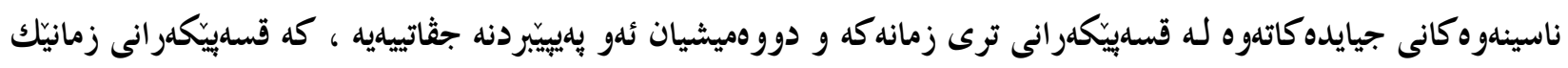

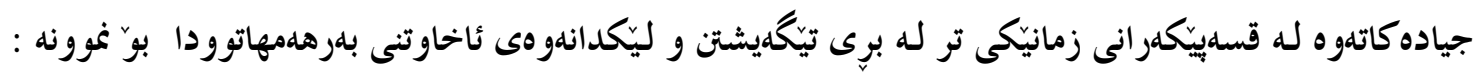

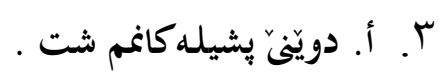

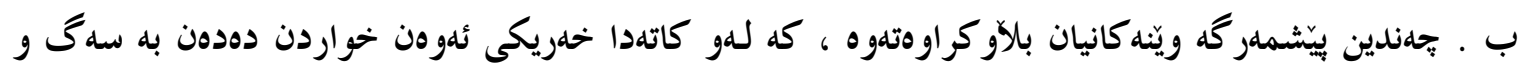
يشيله للهبلره كانى جهنكُا.

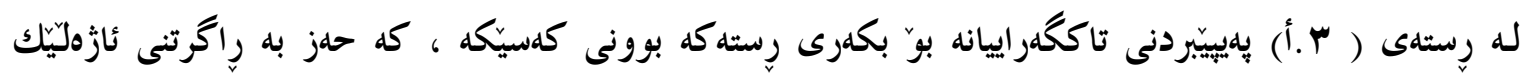

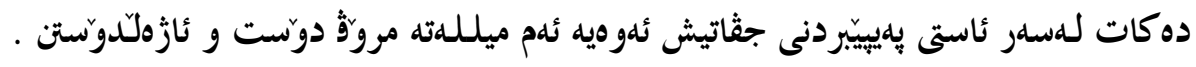




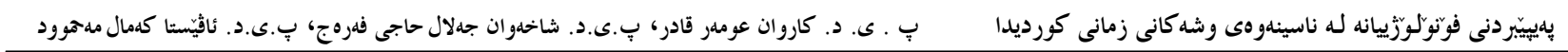

McClelland and Rumelhart (1981:300)

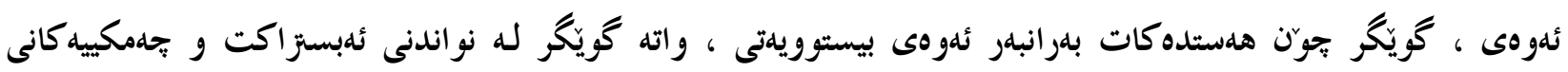

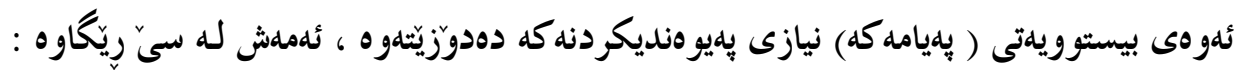

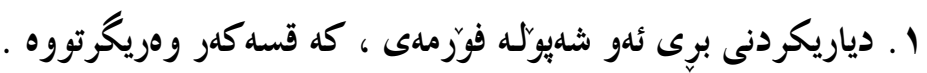

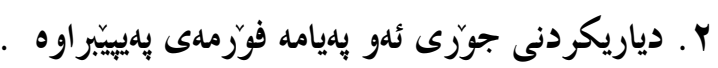

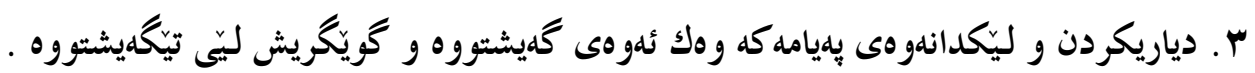

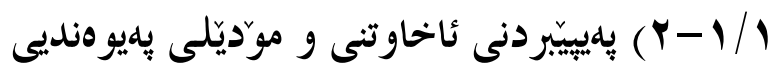

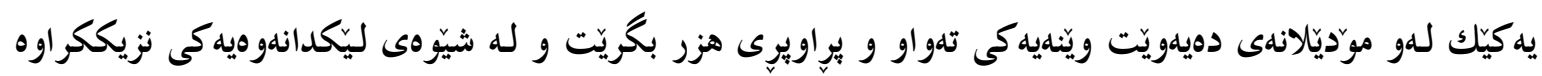

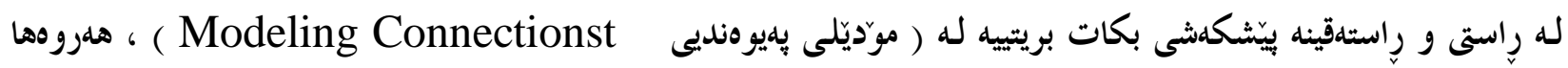

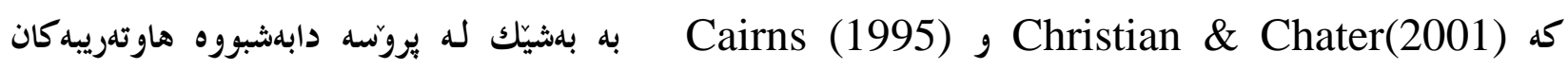

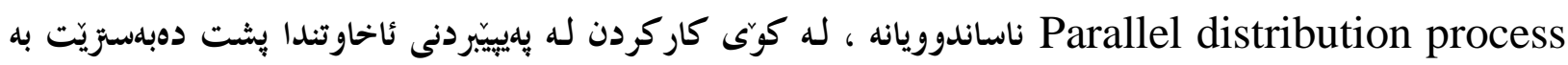
تيّورى ( كاراكردنى كارليّكردن Interactive Activation )، كه له سنوور و جيَّوهى ئهم مودّدِّلهدايه . خودى ئهم

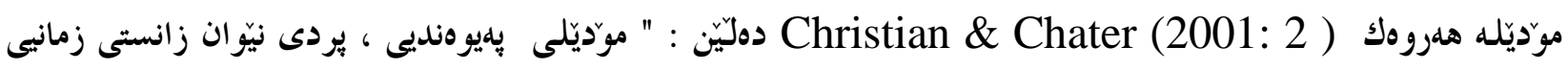

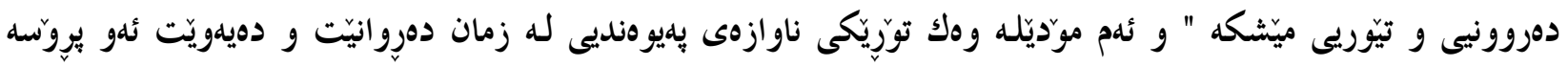

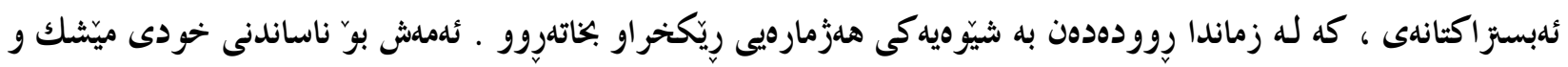

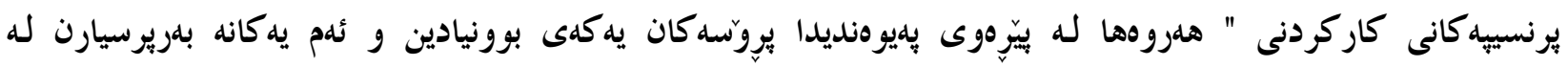

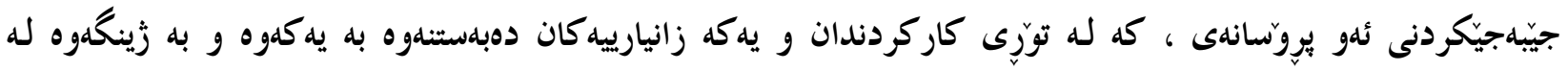

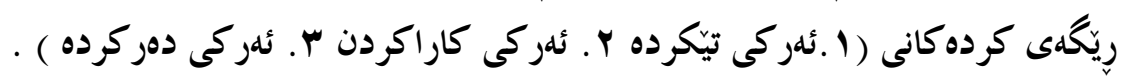

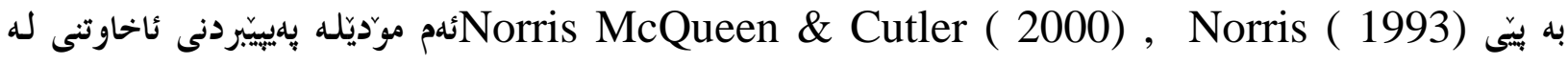

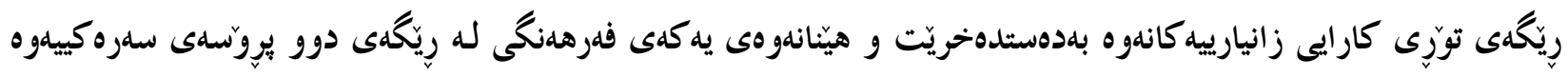

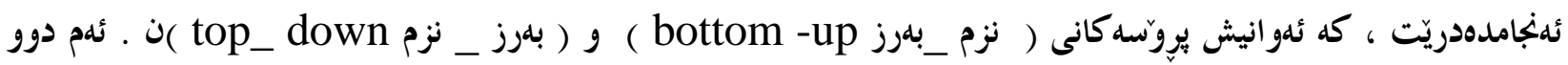

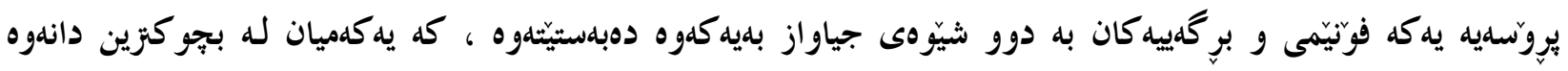

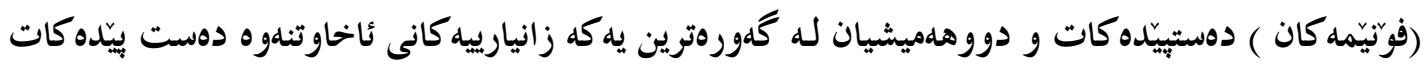

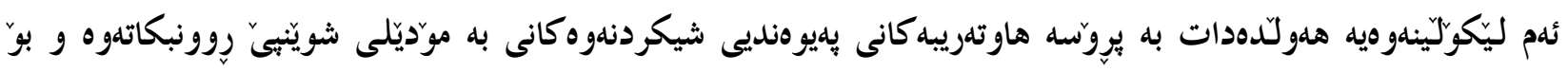

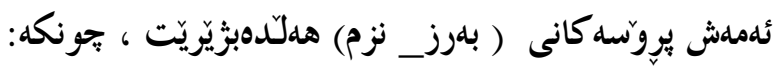

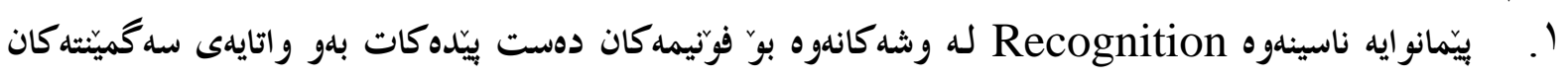

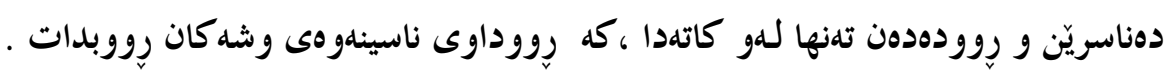

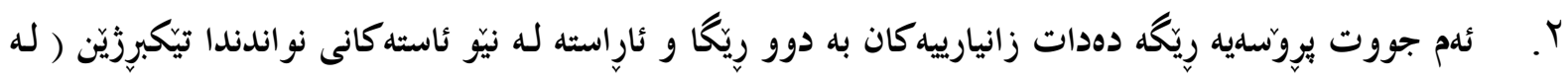

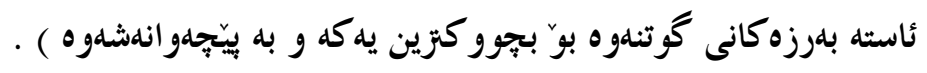




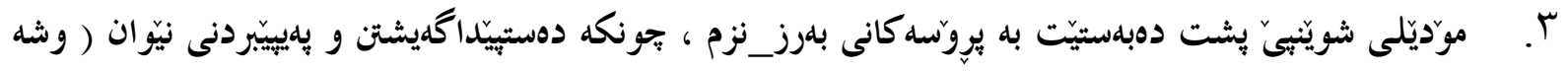

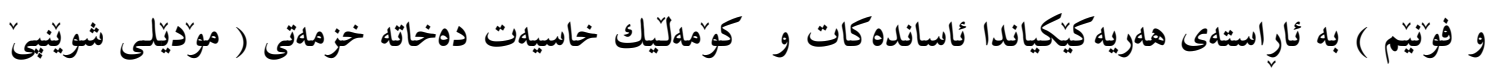
Trace model

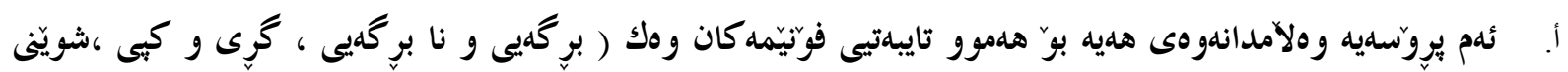

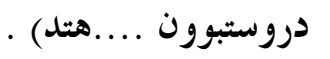

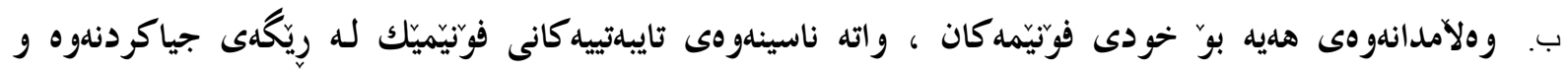

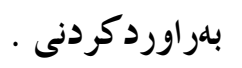

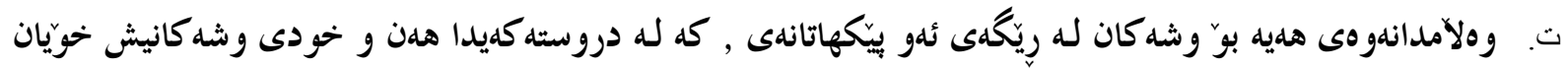

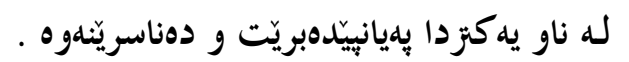

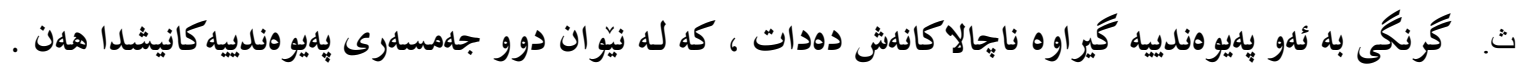

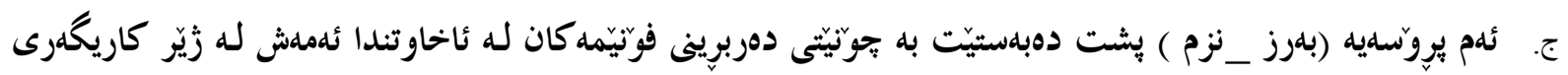

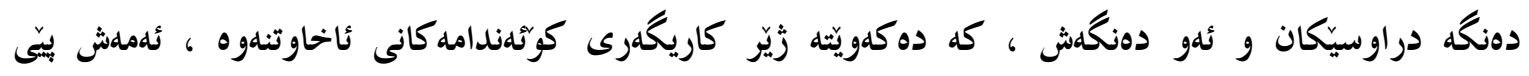

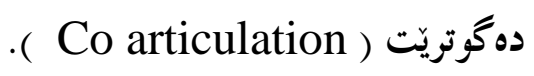

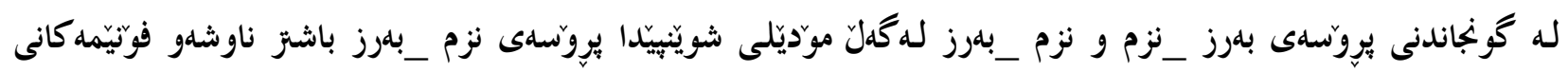

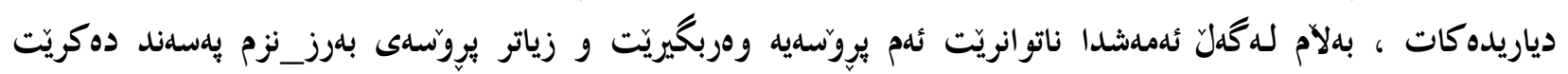
McClelland and Rumelhart (1988)

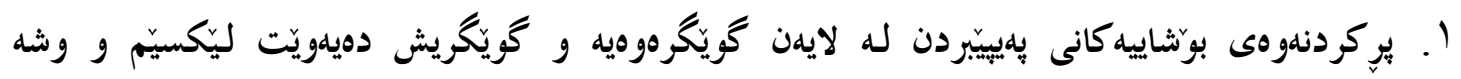

$$
\text { بناسيّنهوه ه }
$$

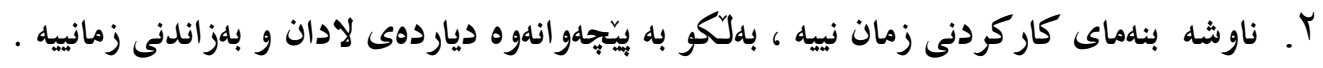

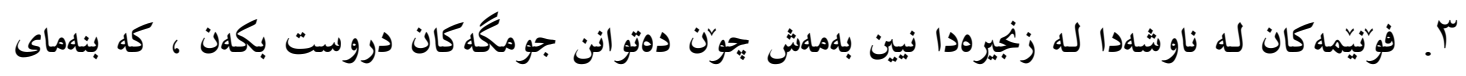

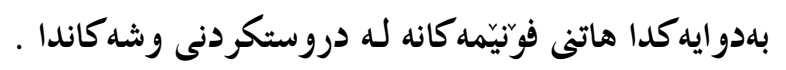

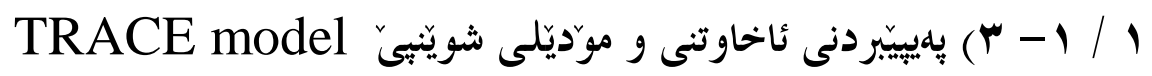

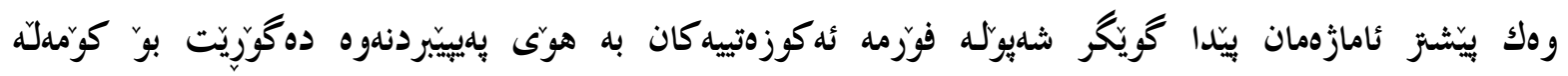

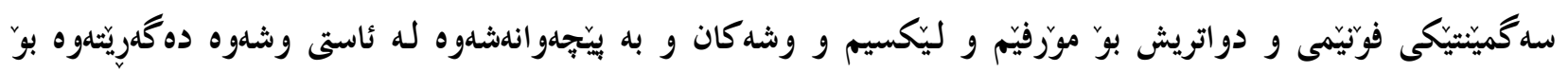

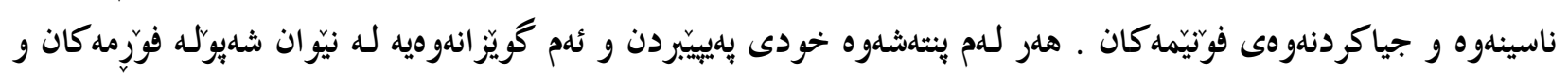

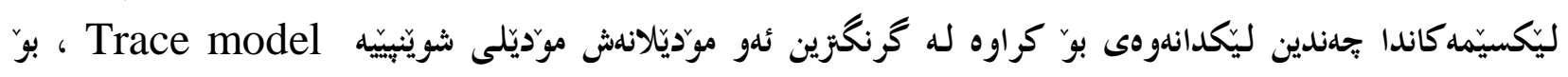

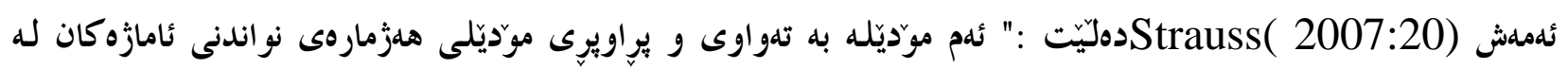




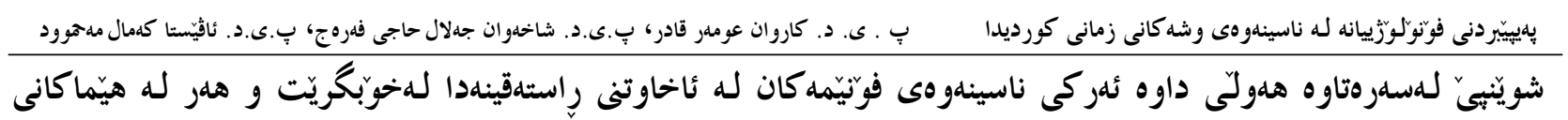

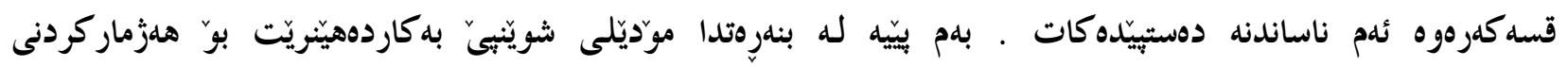

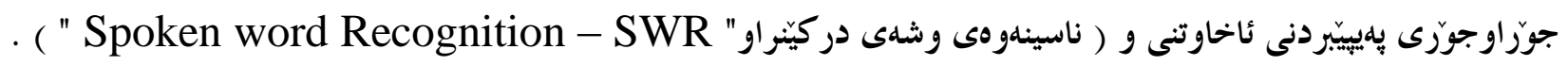

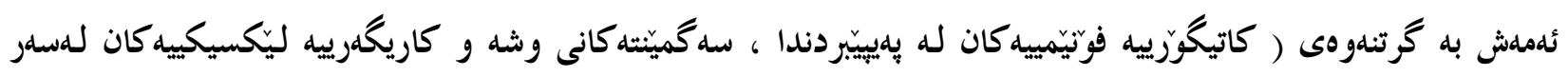

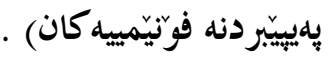

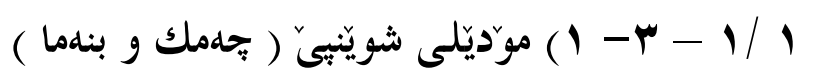

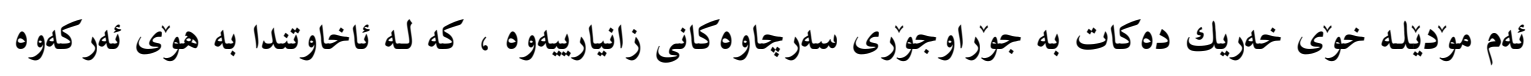

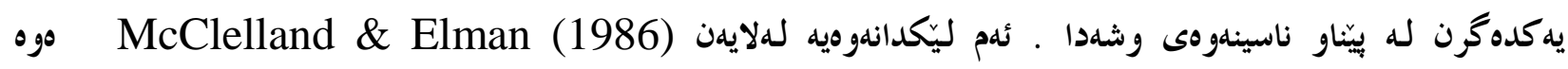

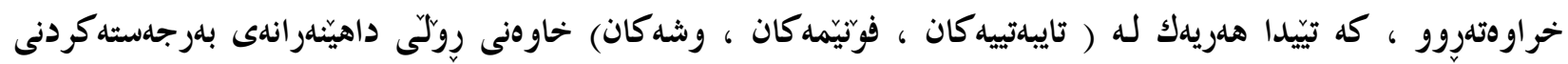

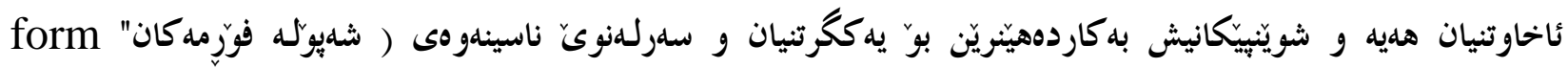
. or " wave

موّديّله كه دابهش دهبيّت بوّ دوو وهجِه موّديّل ، كه ئهو انيش بريتين له :

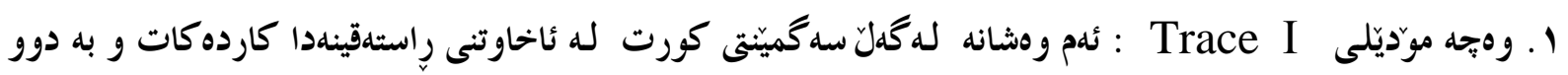

شيّزه كارى لهسهر ناسينهوهى فوَّيَمه كان كردووه :

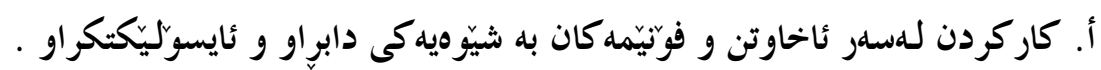

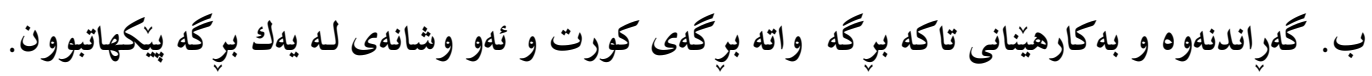

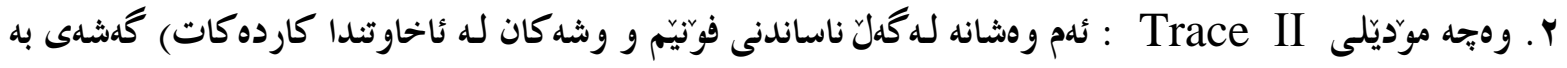

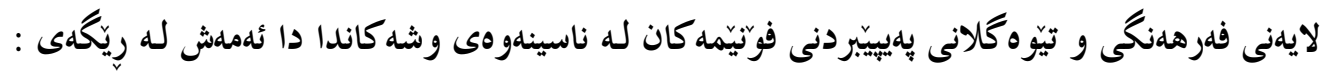

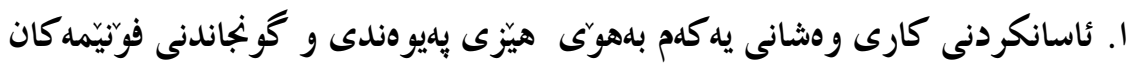

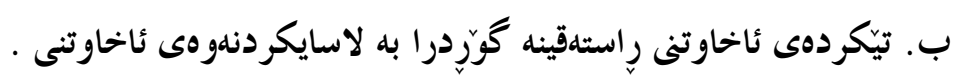

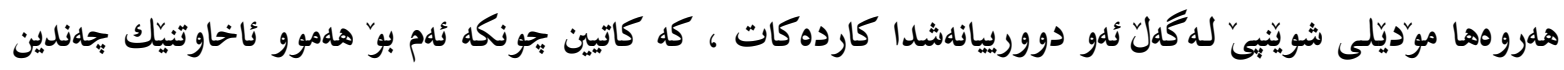

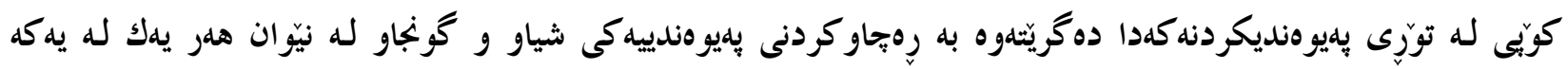
كوَيبكراوه كاندا . لايهنيّكى ترى تيّورييه كه، كه (1988) Elman \&McClelland خستويانهتهروو بريتييه لـه ليَّكدانهوهى دياردهى جومخديى بوون Coarticulation Phenomenon 


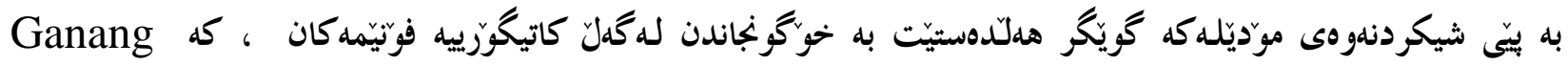

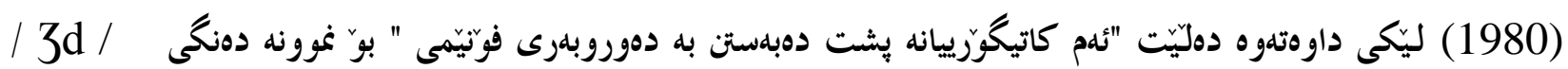

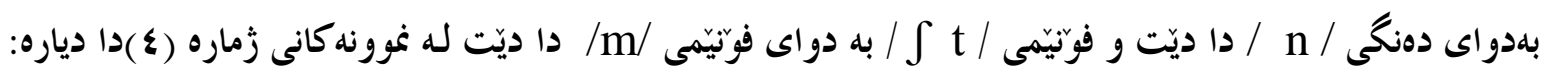

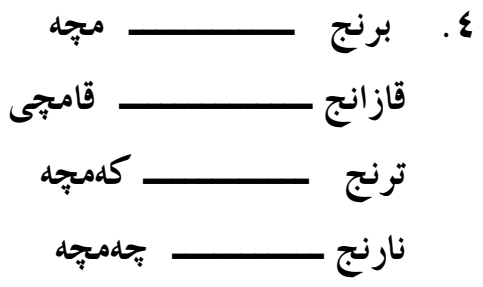

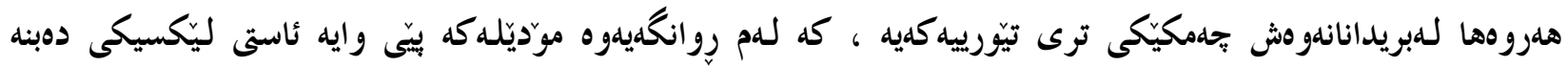

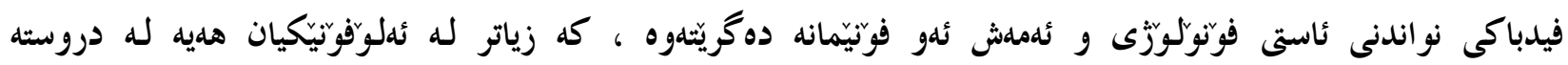

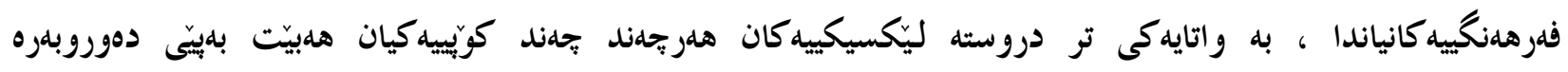

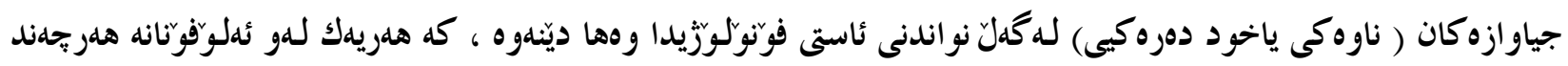

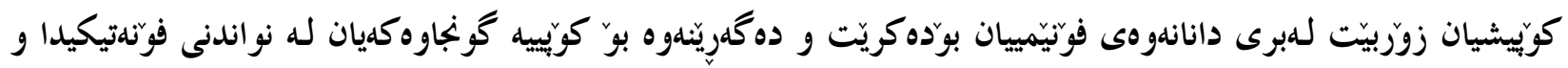
به سانايانه وشه بنجييه كان دهناسريّنهوه بوّ نموونه :

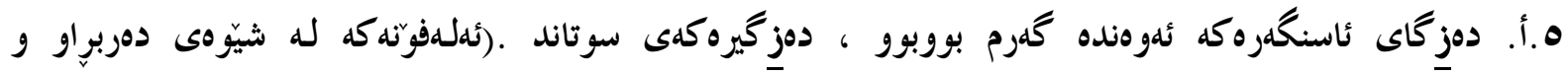

$$
\text { نوسر اويشدا بحdسياوه ) }
$$

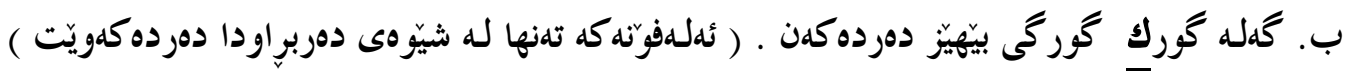

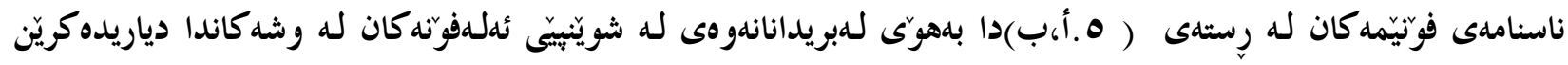

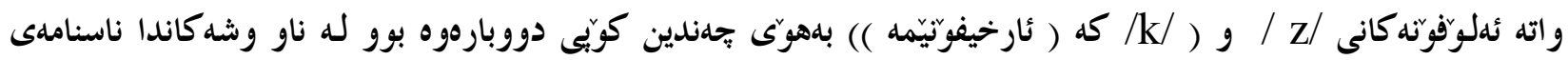

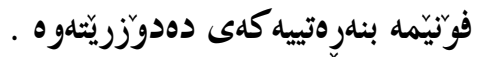

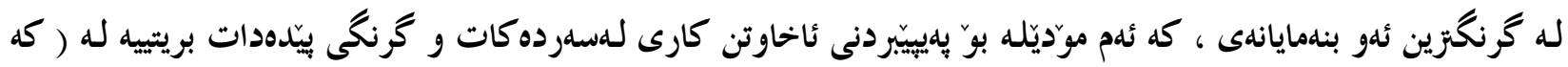

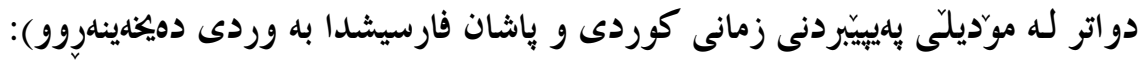

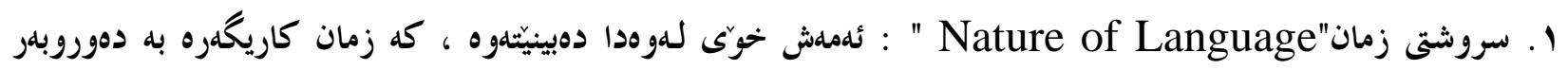
بلهُشتى و ناتوانيّت ليّى دابِريتت .

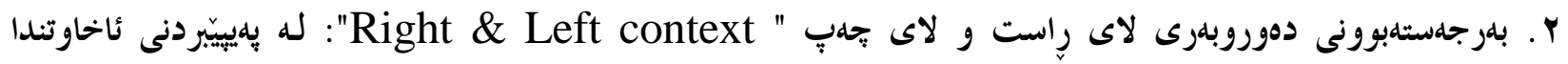

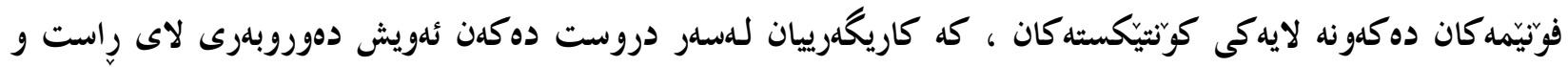

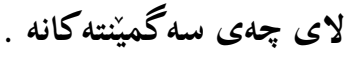

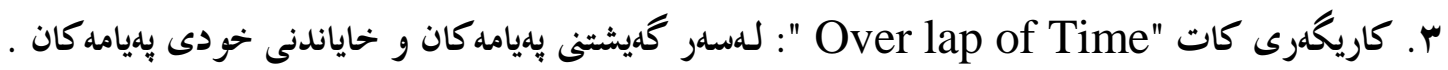

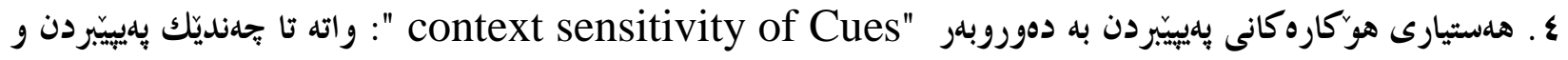

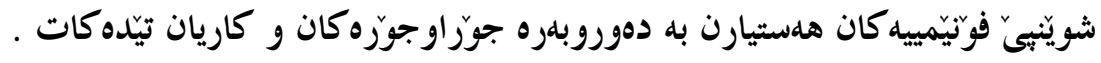




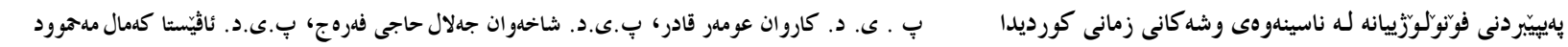

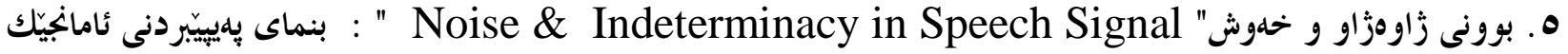

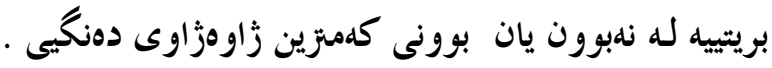

$$
\begin{aligned}
& \text { 1/11 }
\end{aligned}
$$

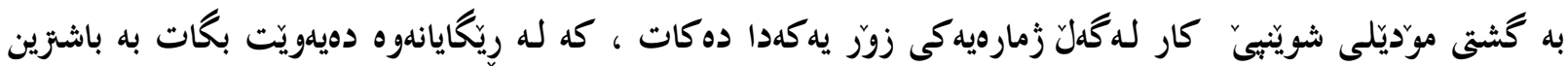

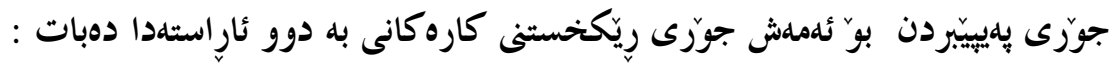

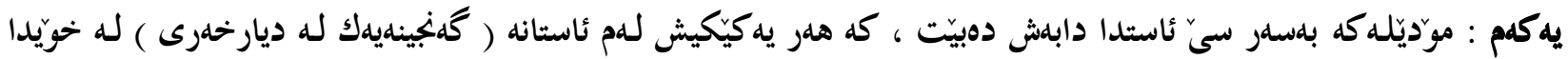

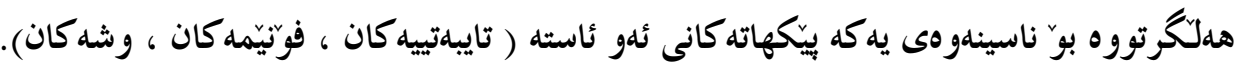

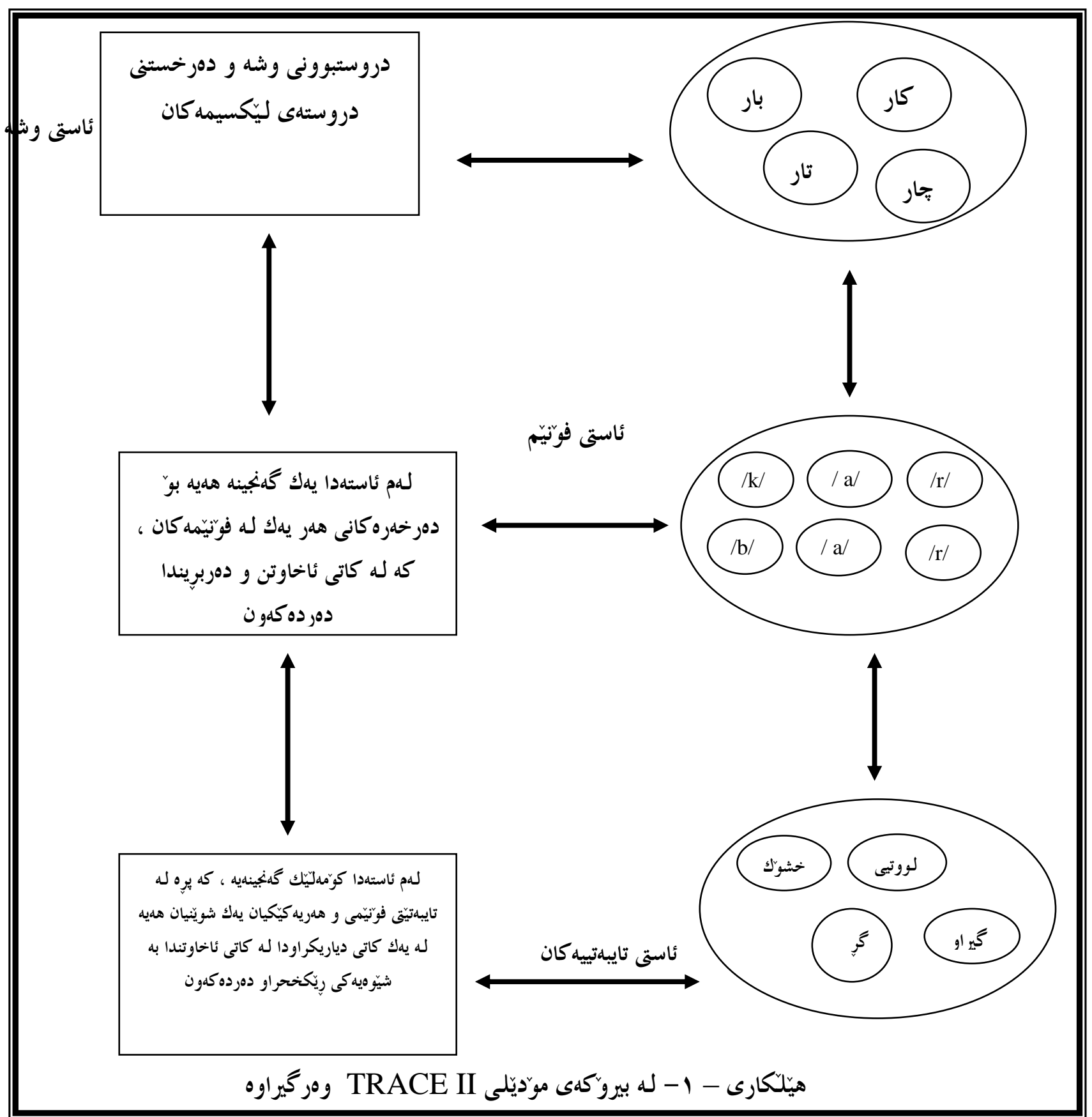




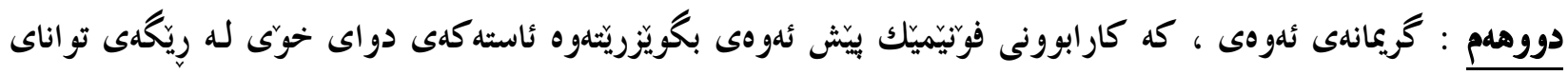

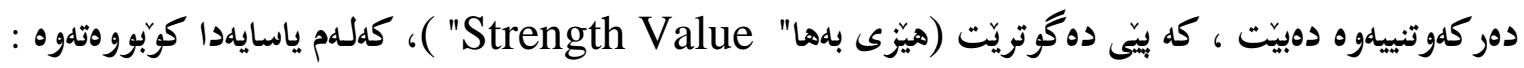

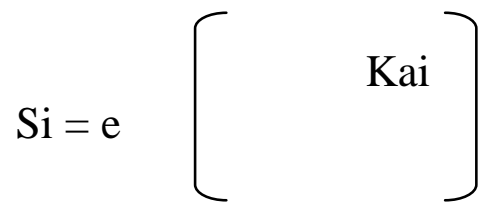

كه : ياساكه دهرهيّنانى تواناى لله خوّدابوونه : : Si به تايبهت نموونهى (بَ).

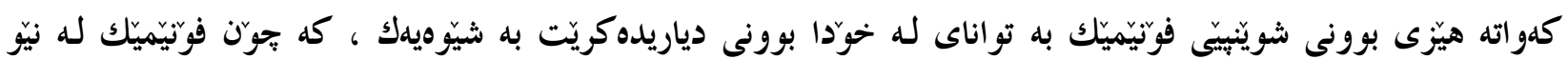

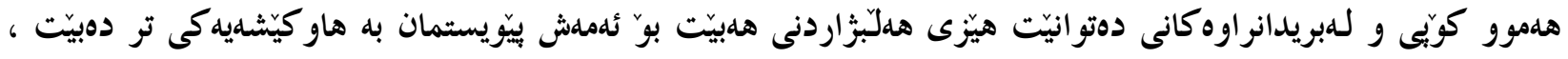

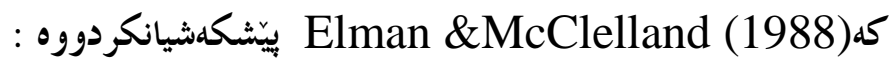

$$
\left[\frac{\mathrm{P}(\mathrm{Ri})}{\Sigma \mathrm{Si}}=\mathrm{S}\right]
$$

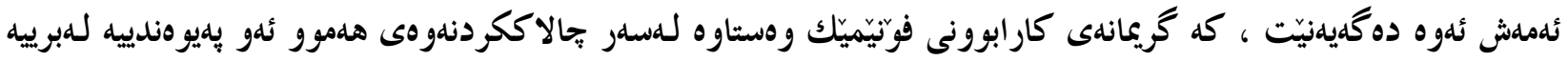

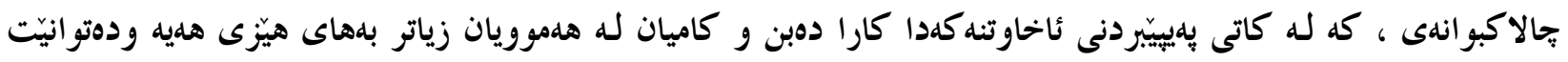

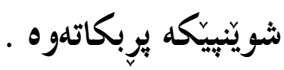

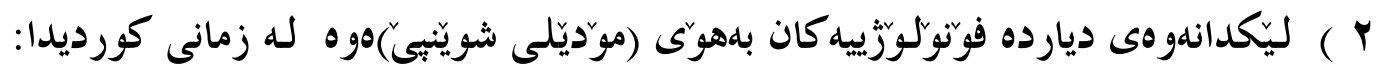

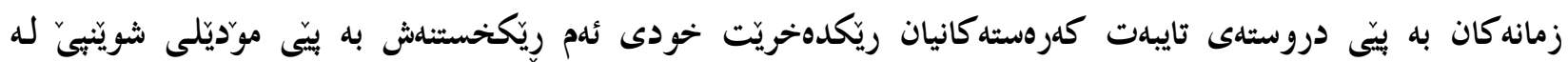

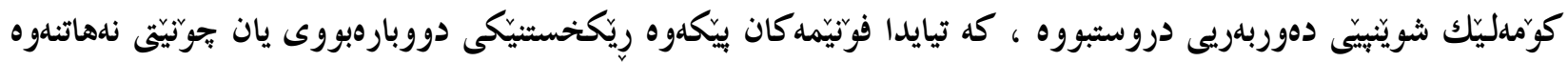
و لادان لدو رِيَكخستنه دهخاتهروو .

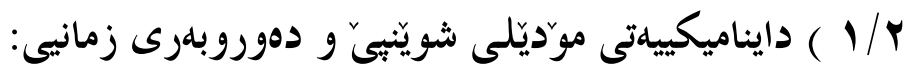

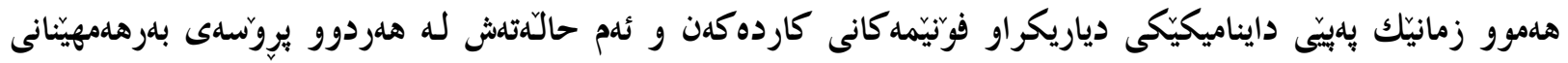

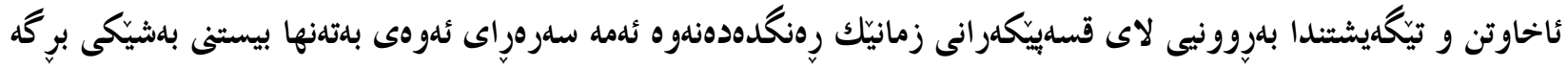

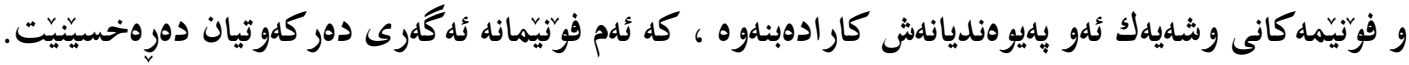




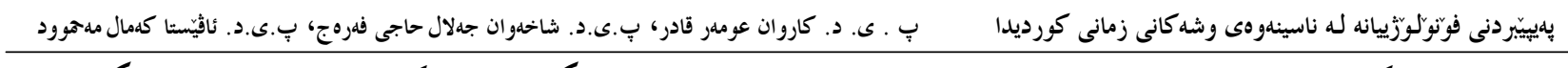

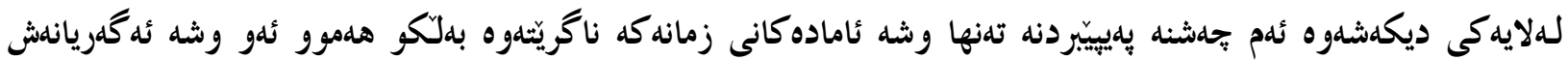

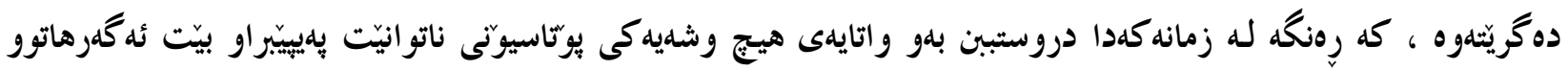

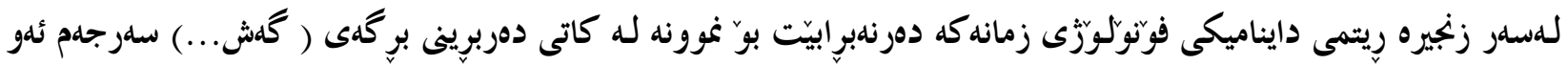

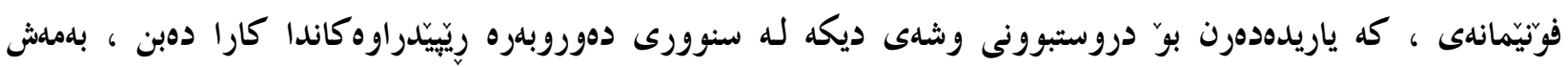

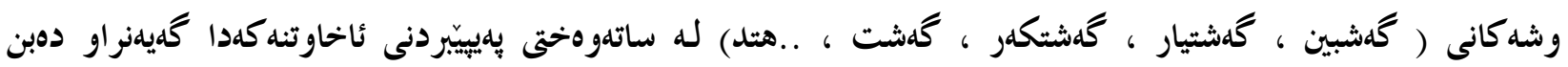

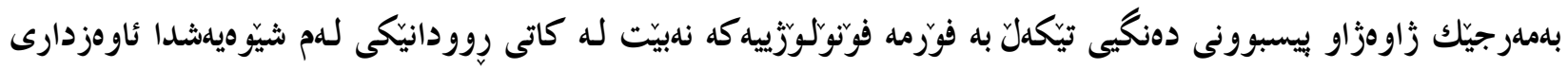

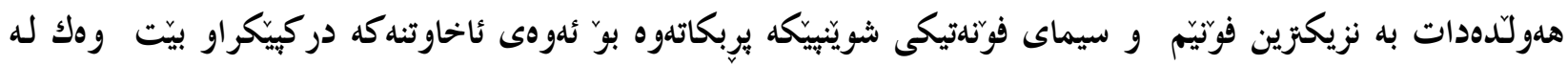

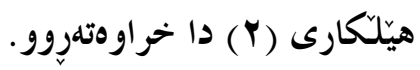

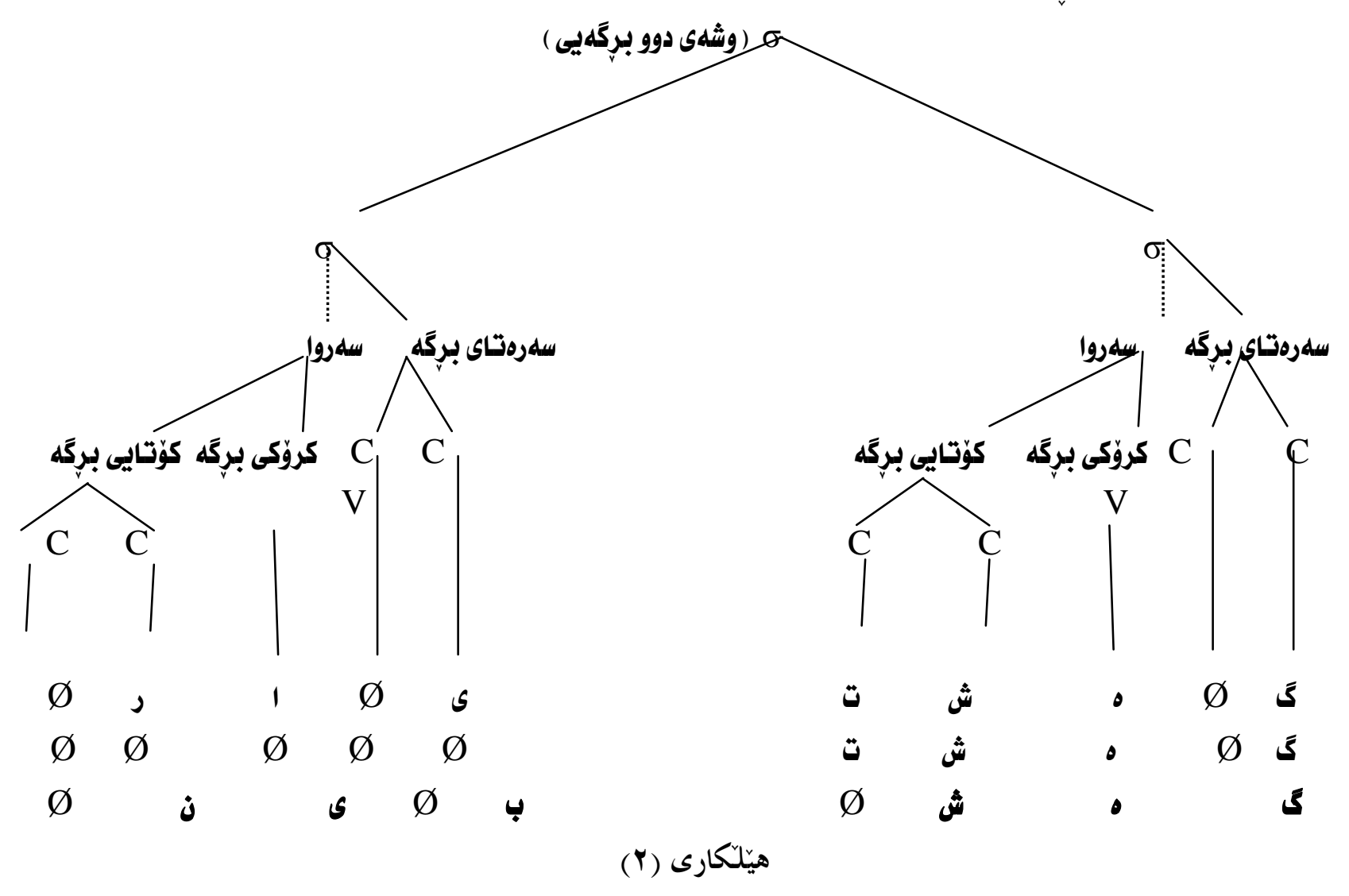




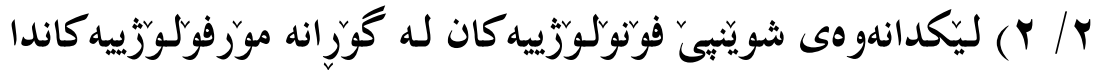

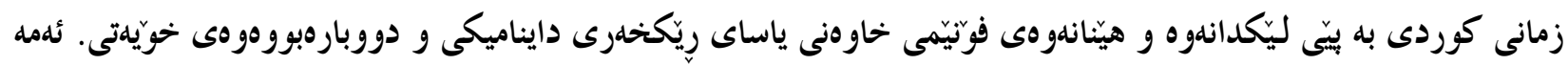

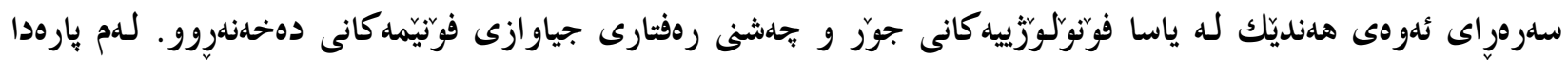

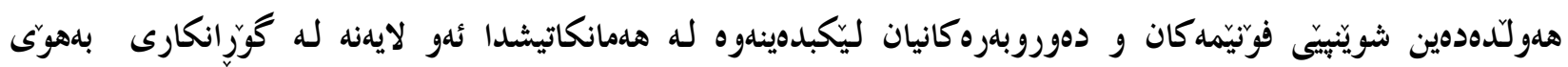

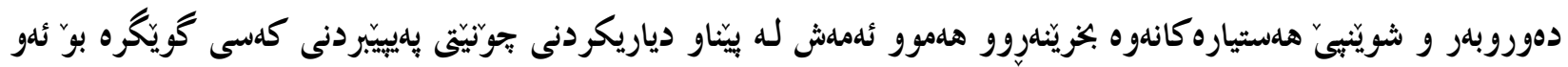

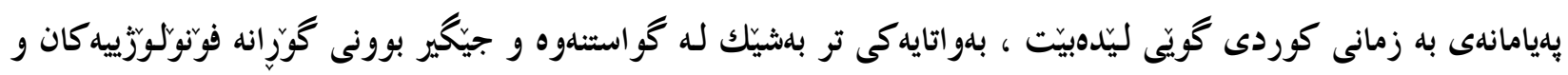

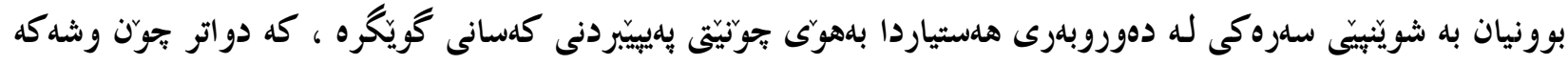

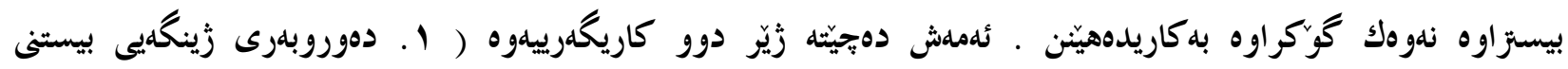

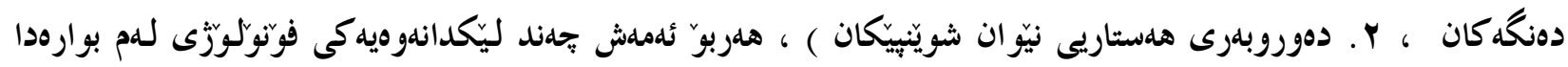
بِيِشكهشده كريّت .

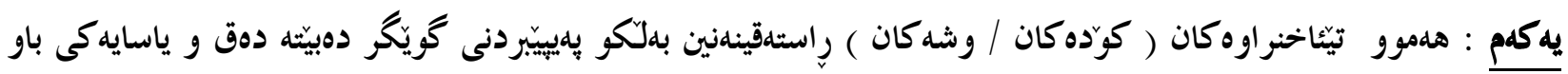

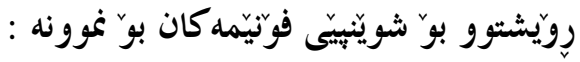

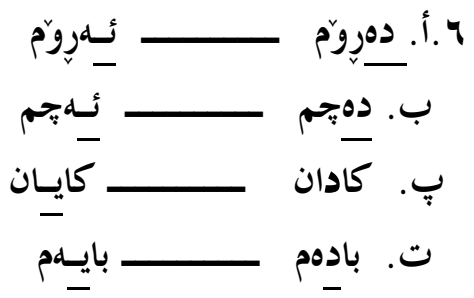

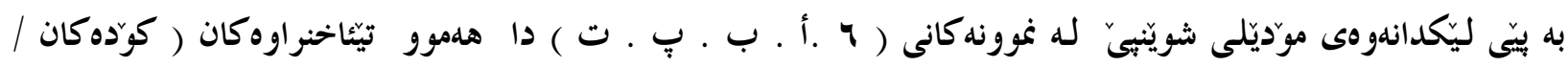

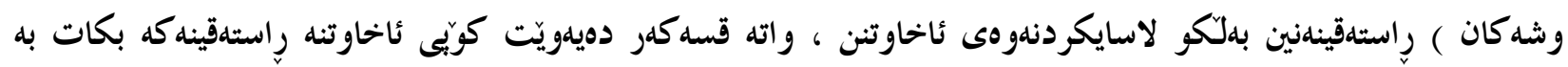

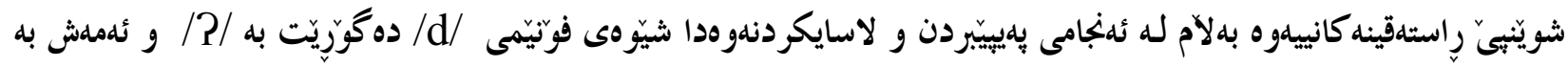

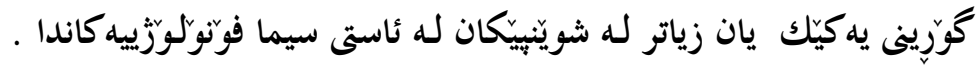

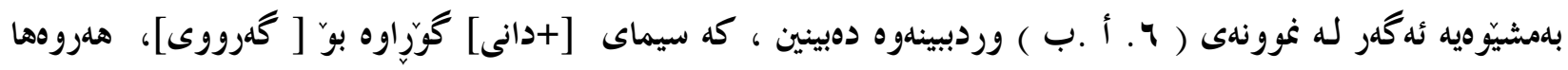

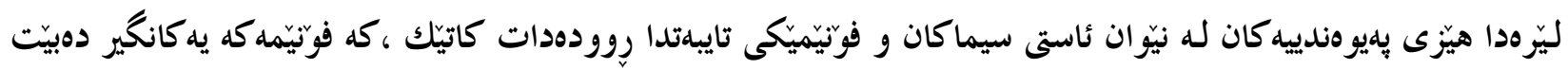

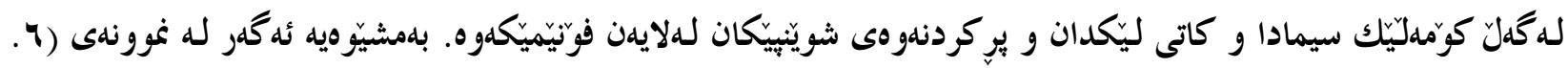

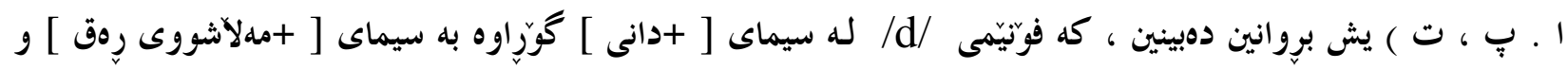

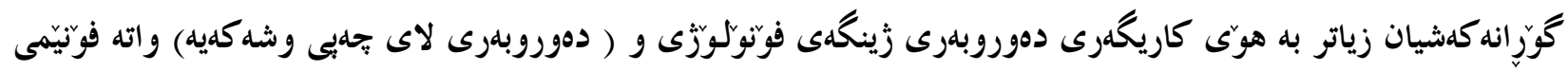

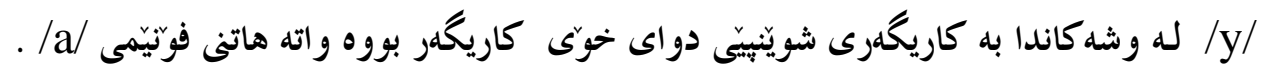

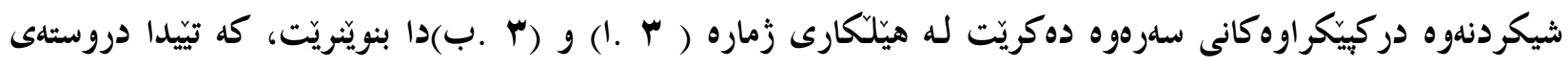

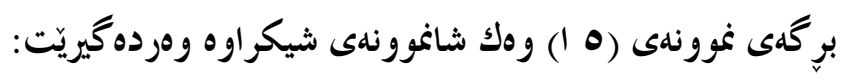




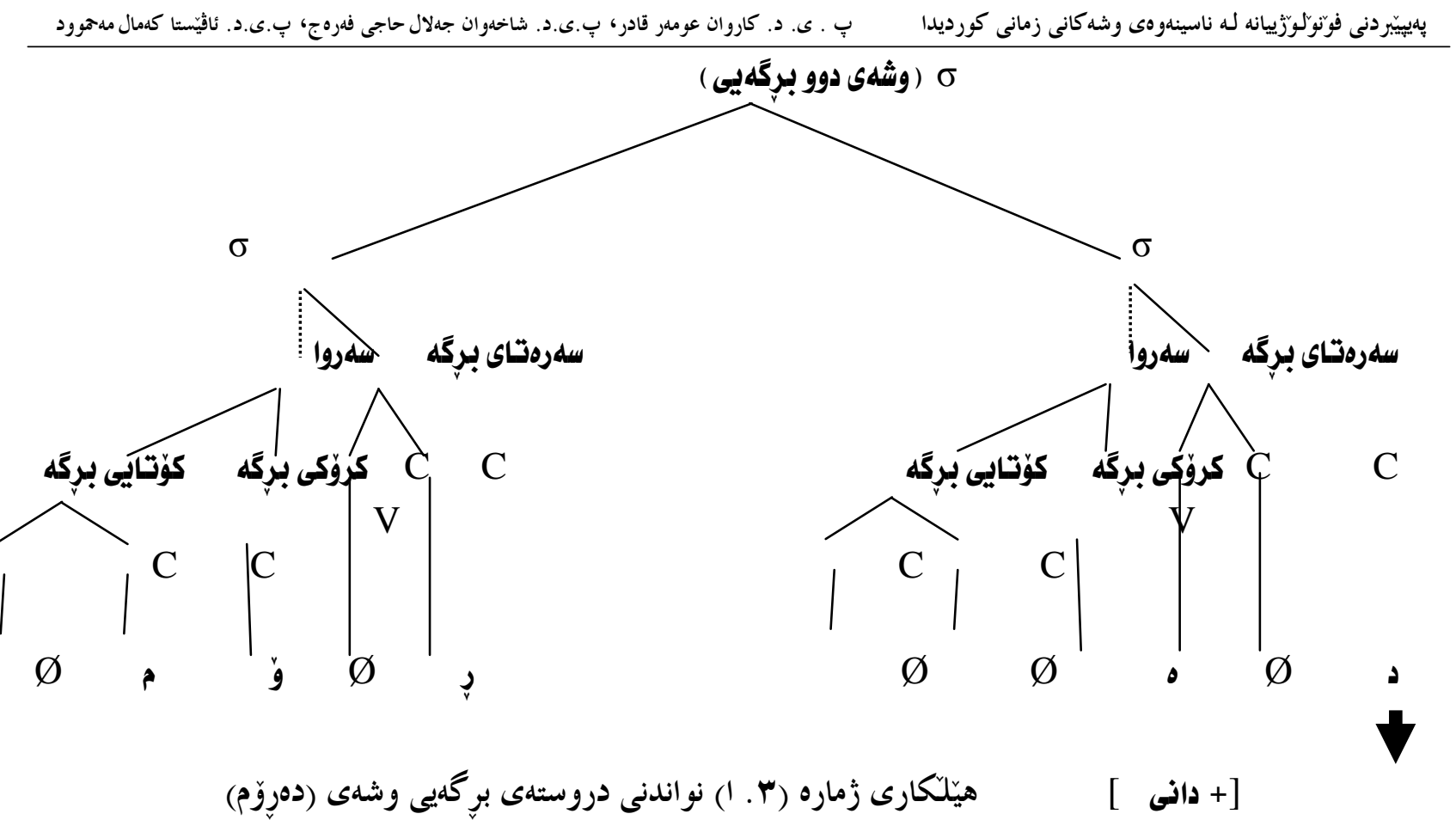

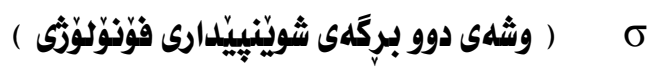
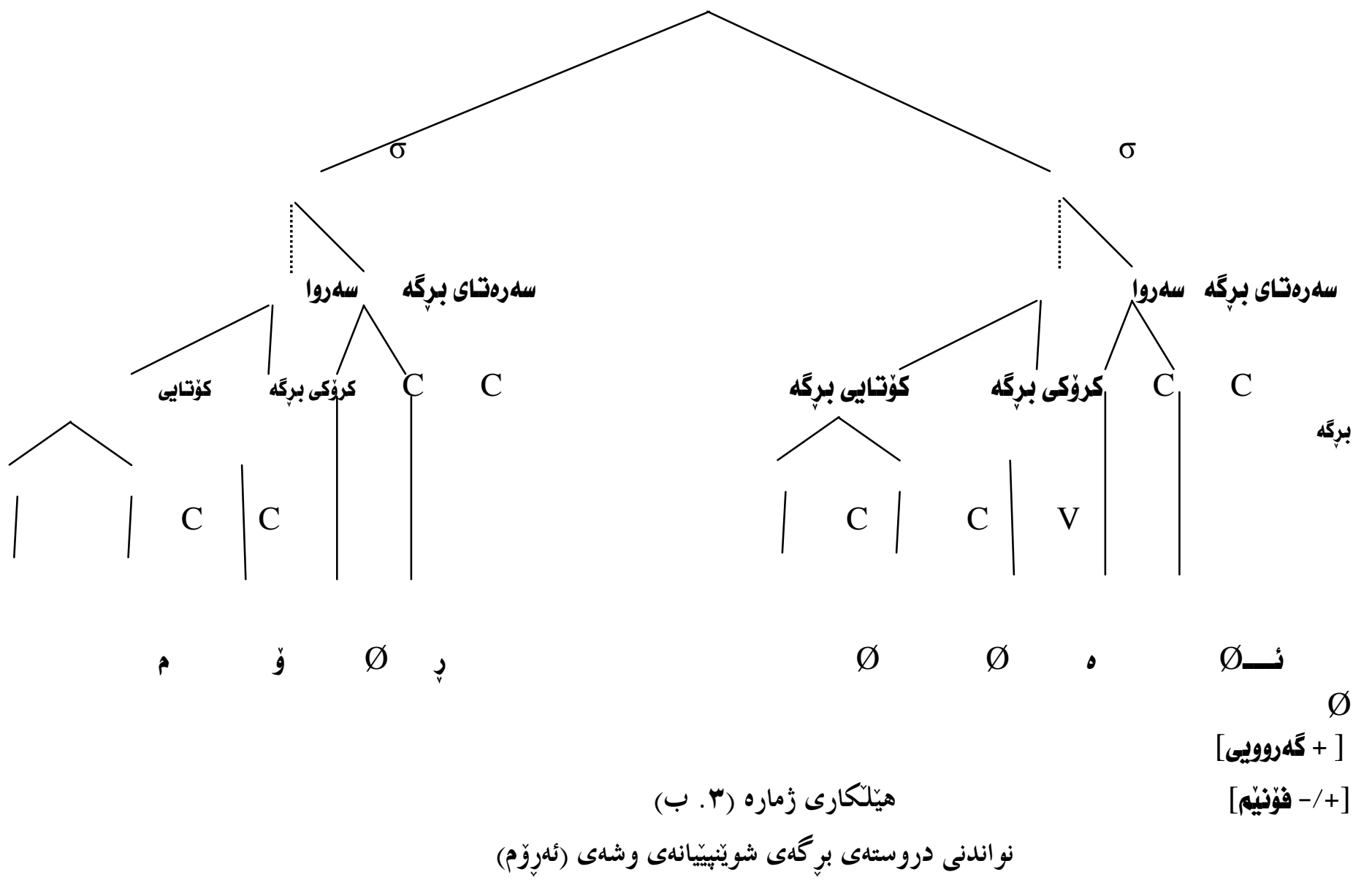


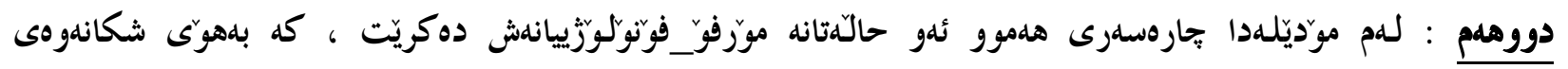

$$
\begin{aligned}
& \text { ريّزمانييهوه دروستدهبن بوّ نغوونه : }
\end{aligned}
$$

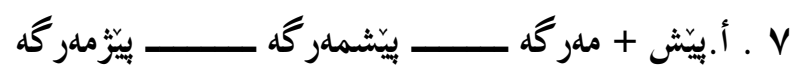

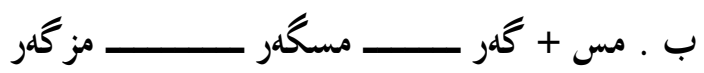

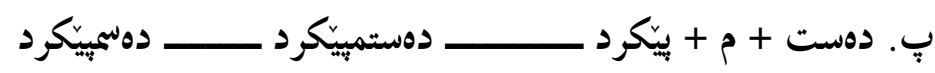

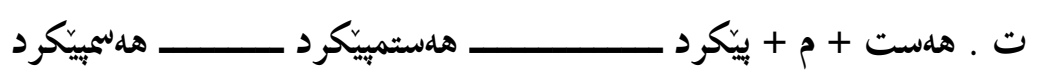

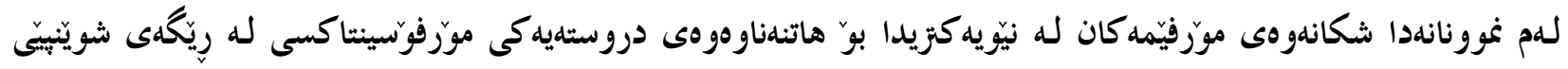

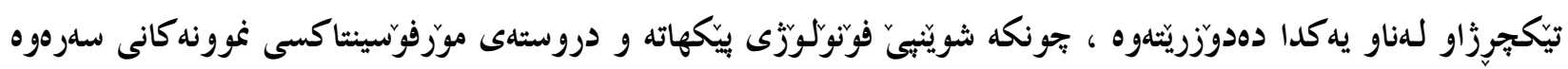

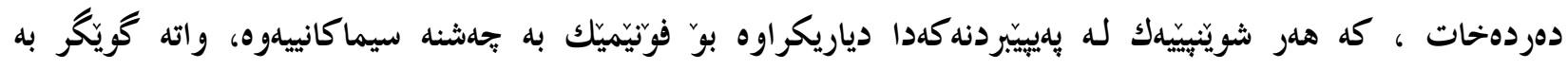

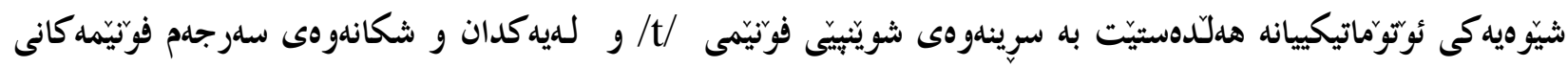
تر له تويّى يهك دروستهى مورفوِّسينتاكسيدا .

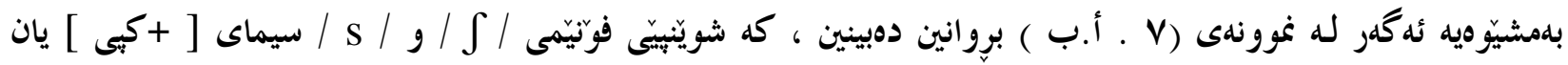

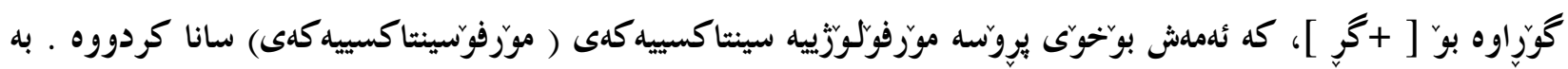

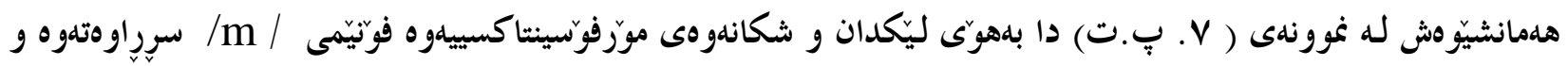

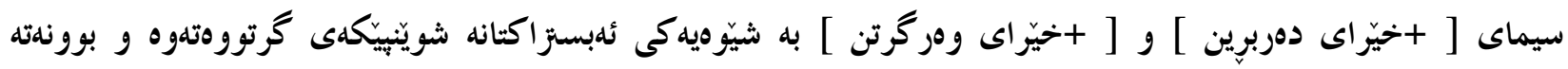

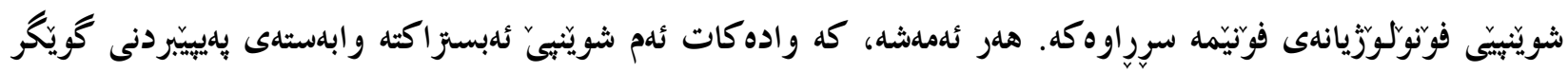
بيّت و ئارهزوومهندانه يُوى بكاتهوه .

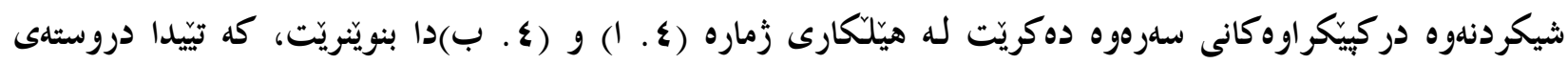

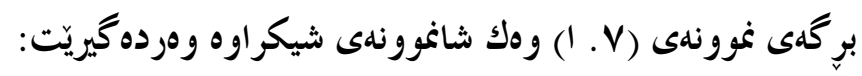




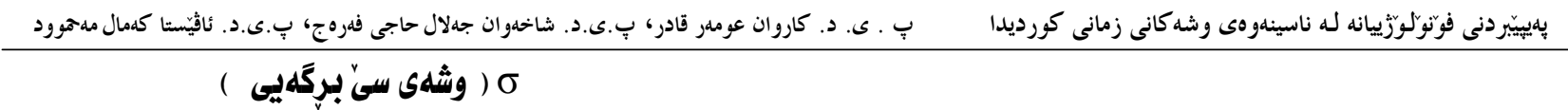

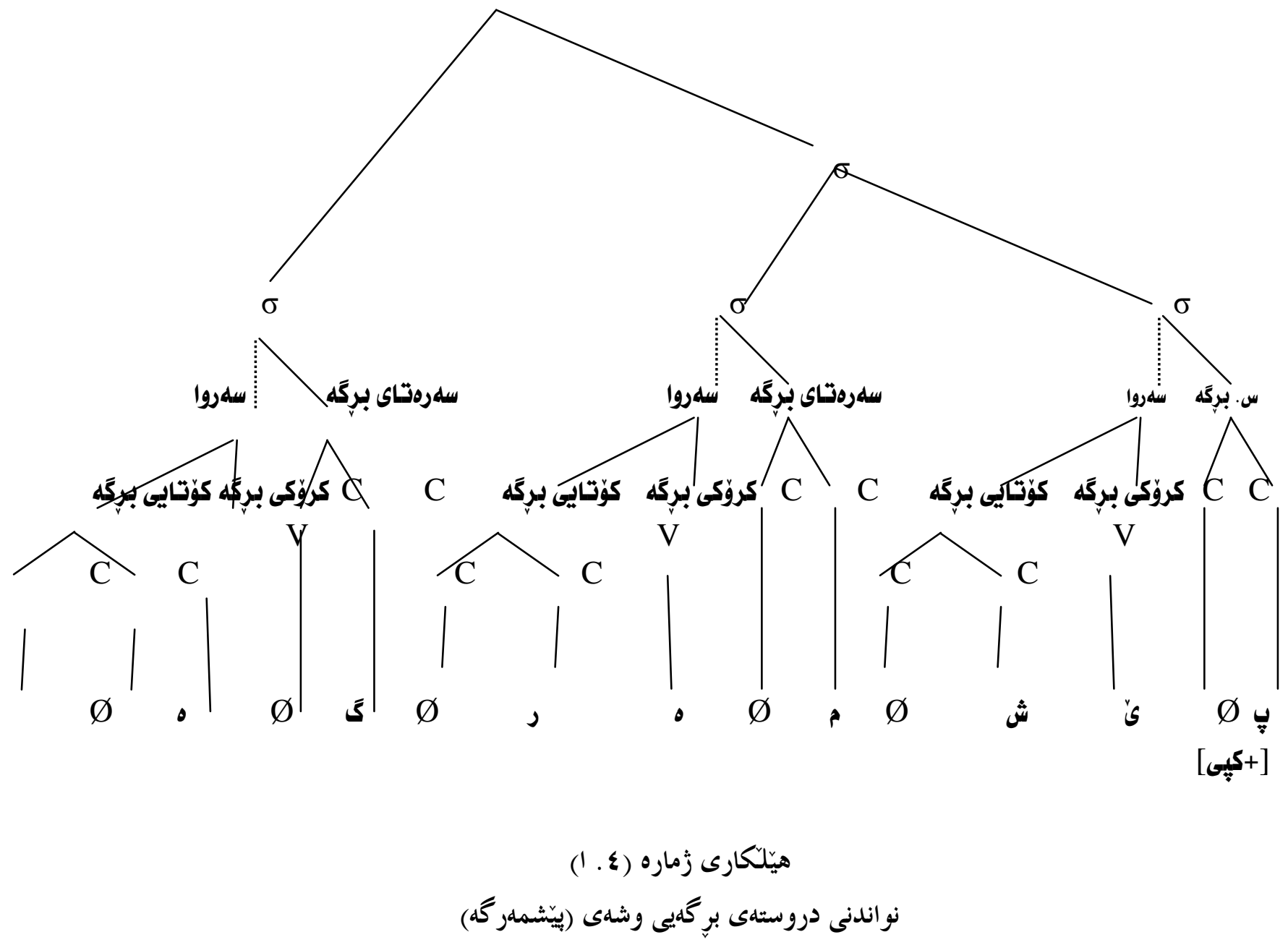




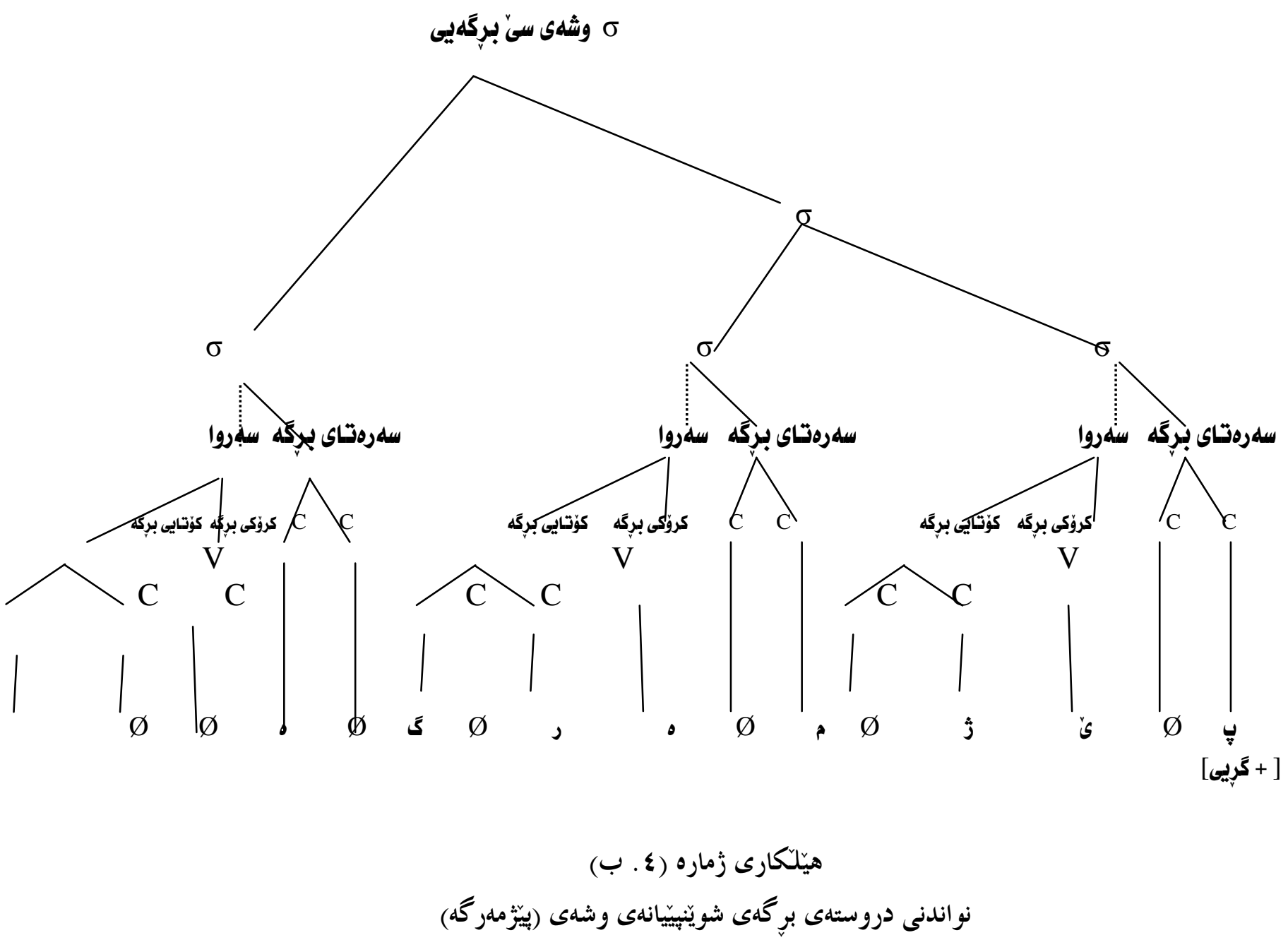

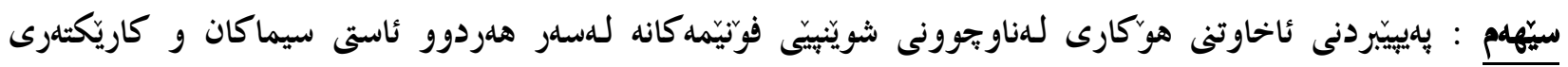

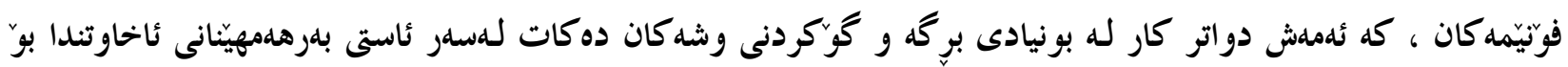

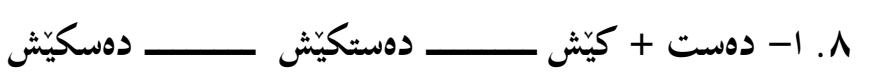

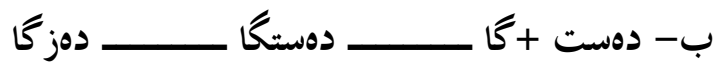

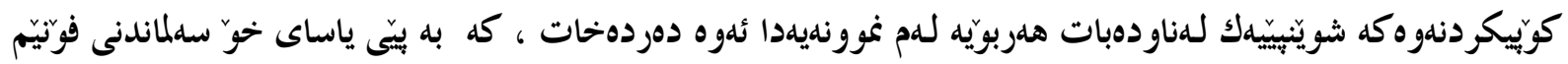

$$
\begin{array}{r}
\mathrm{P}(\mathrm{Ri})=\mathrm{Si} \\
\Sigma \mathrm{Si}
\end{array}
$$

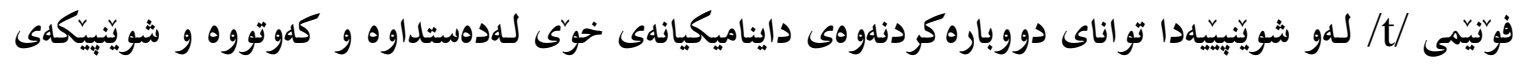

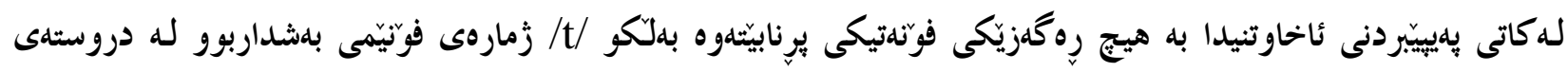

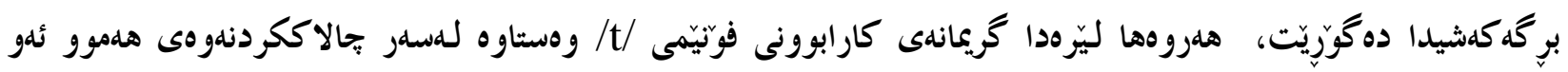




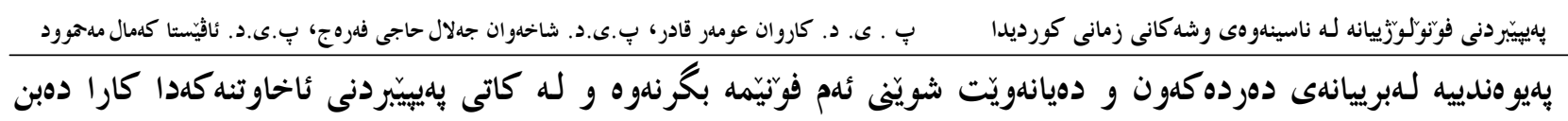

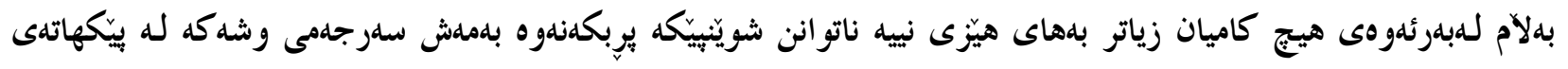

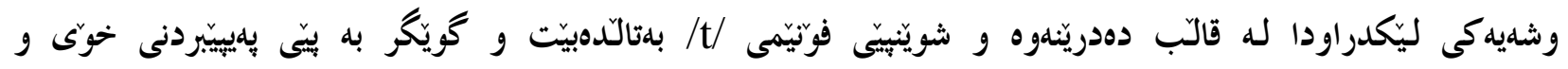

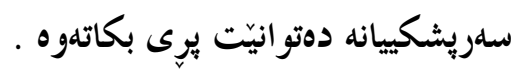

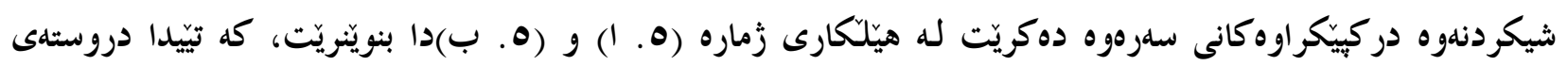

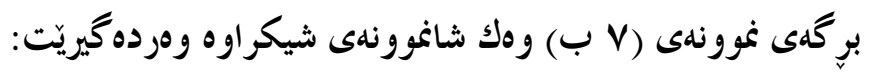

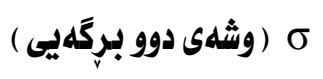

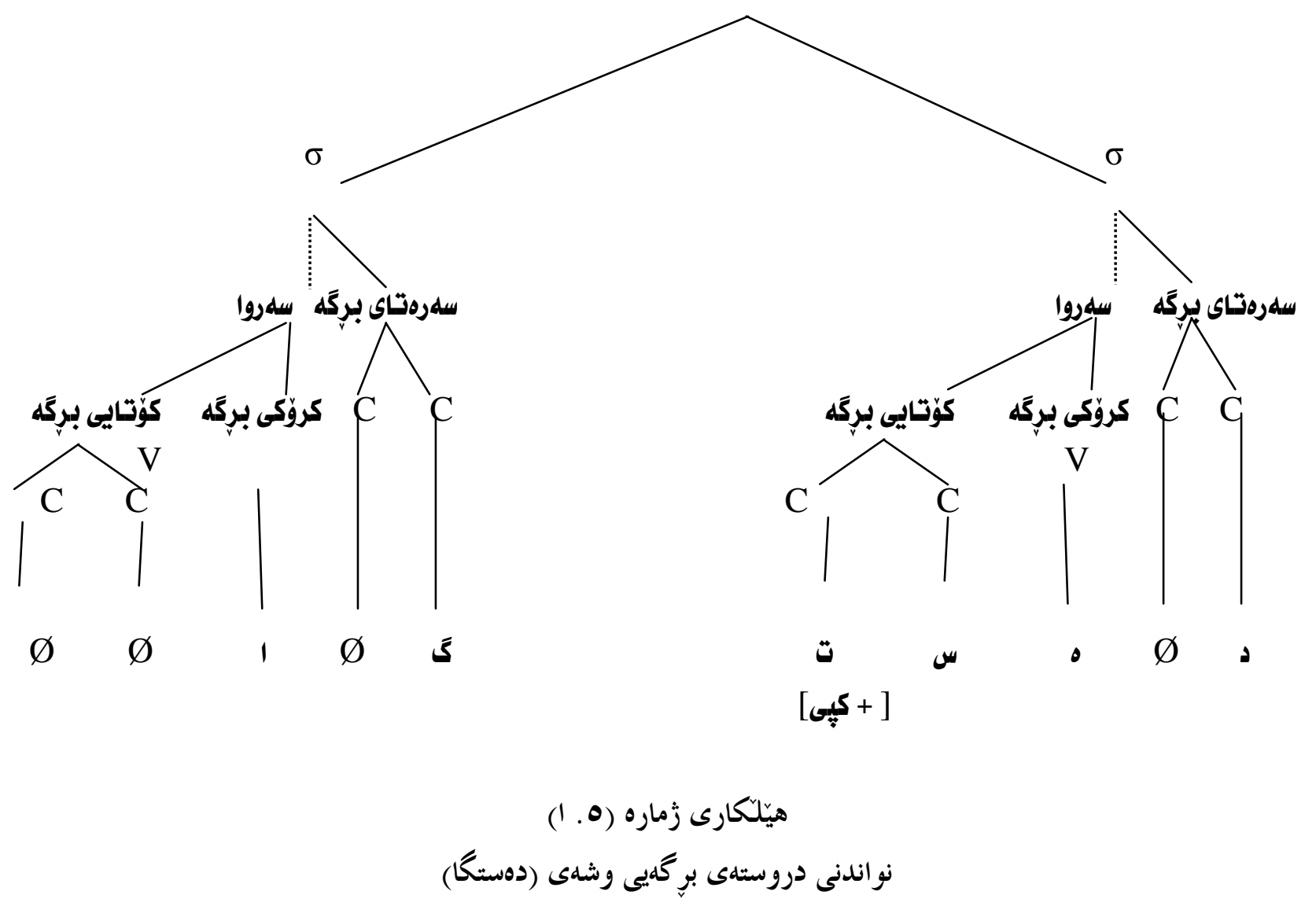




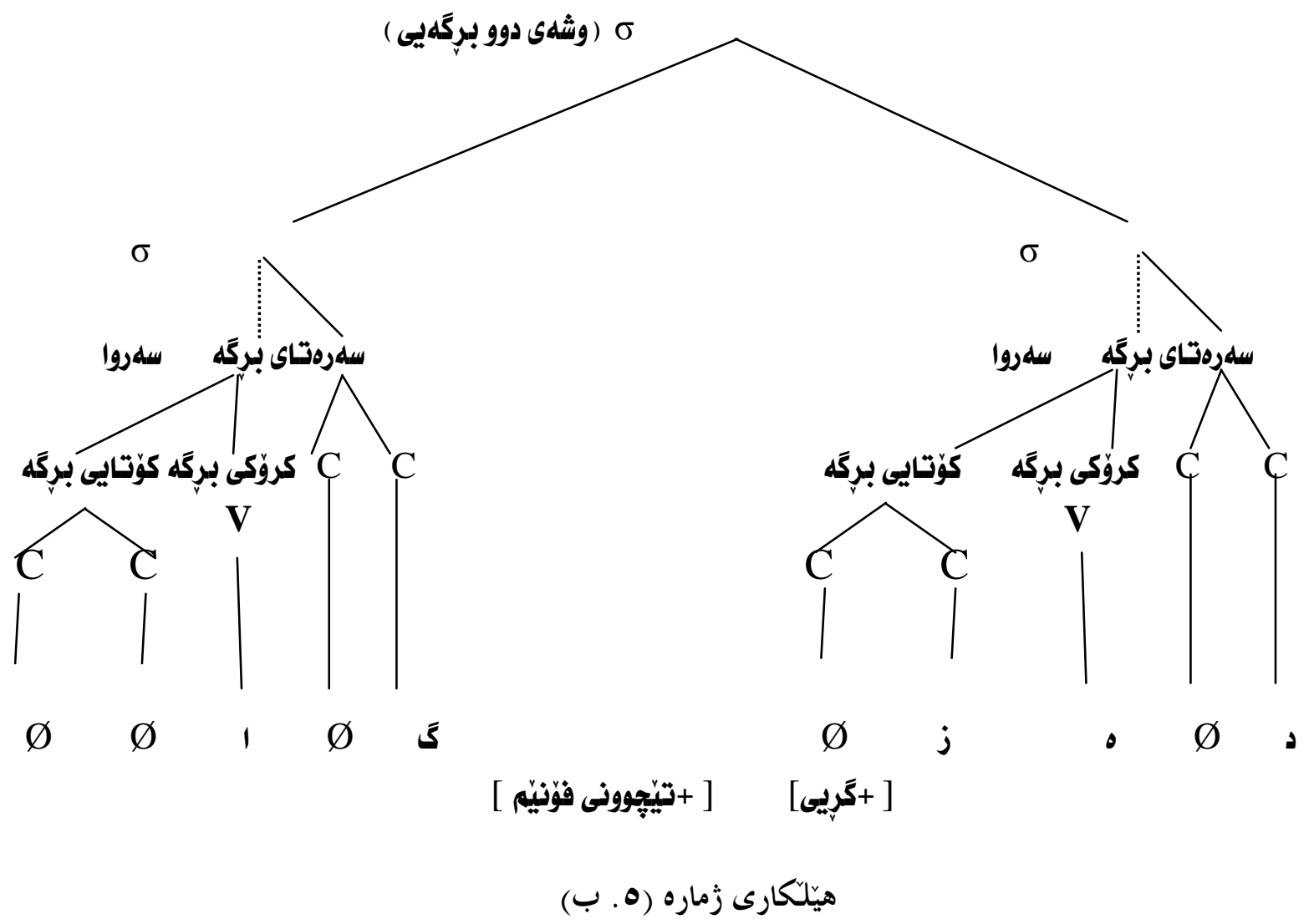

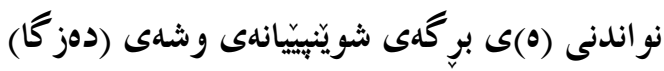

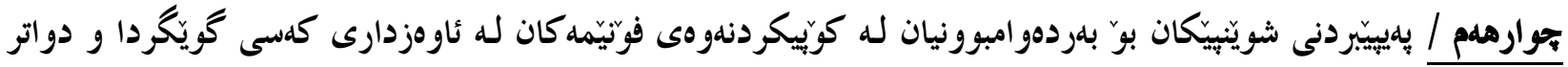

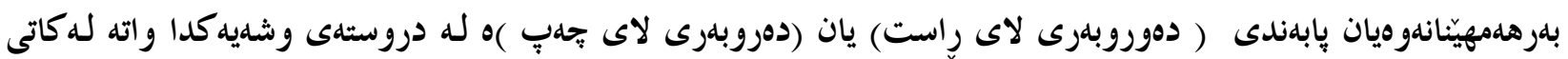

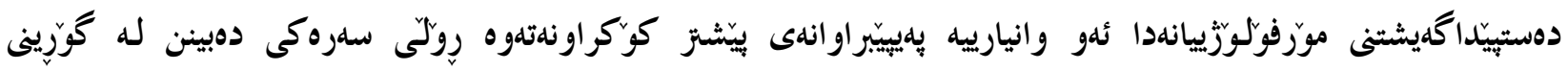

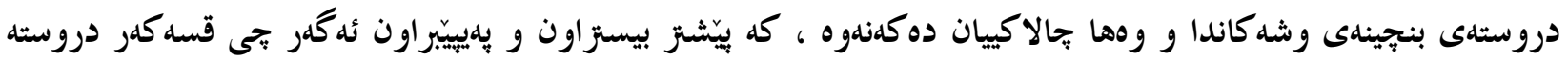

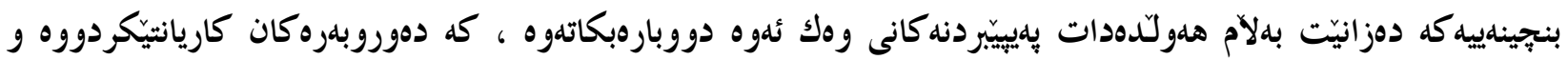

$$
\text { دروستيانكردووه بوّنموونه : }
$$

9 . يلهةم. دهوربلرى لاى راست ( بله بيّى ئلفبيّى عارهبيى)

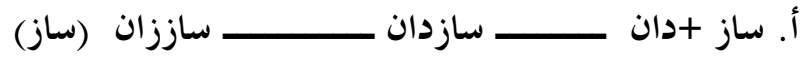

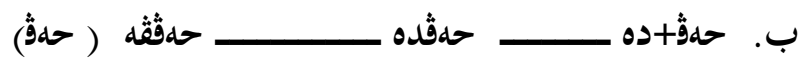

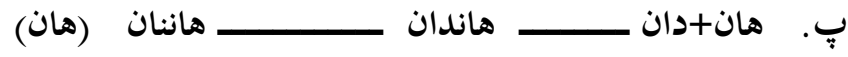

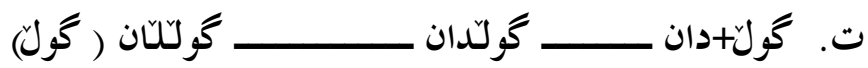

$$
\begin{aligned}
& \text { دووهلم : دهوروبهرى لاى پهلٍ ( به بيّى نئلفبيّى عارهبيى) }
\end{aligned}
$$

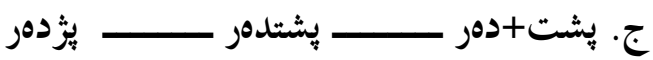




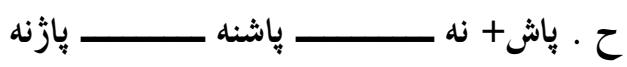

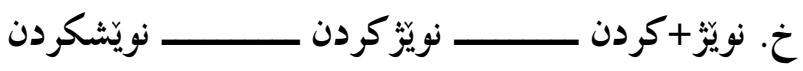

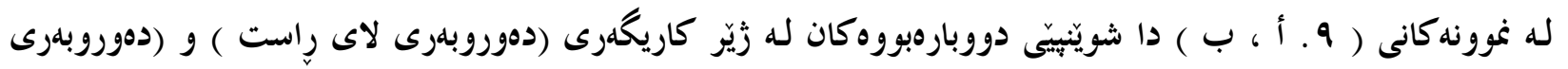

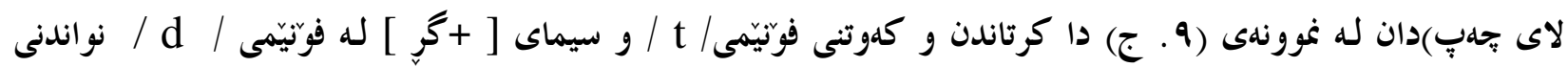

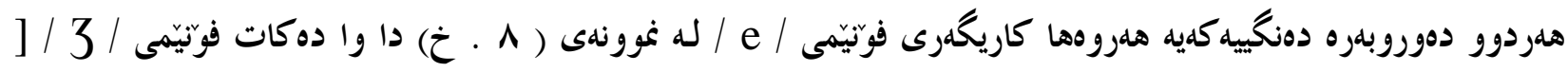

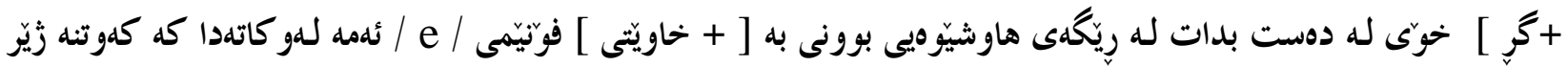

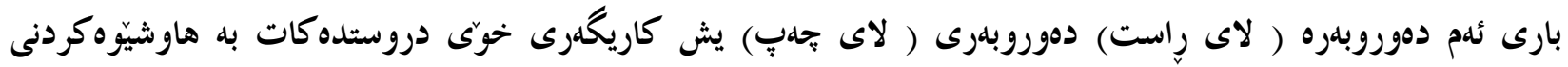

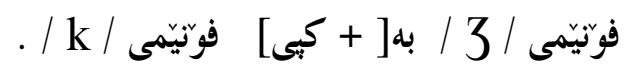

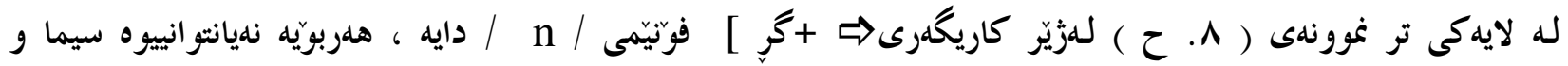

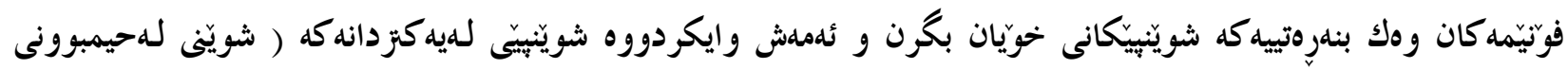

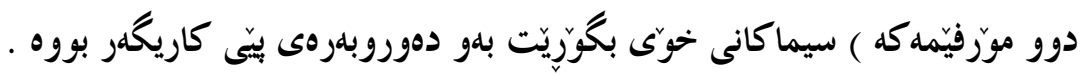

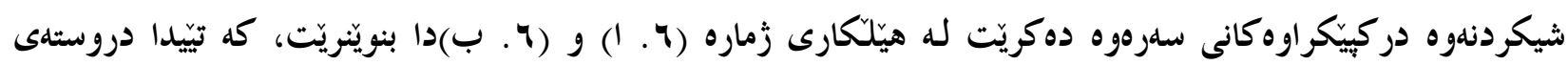

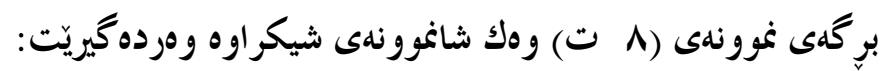

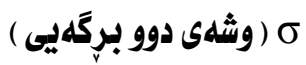

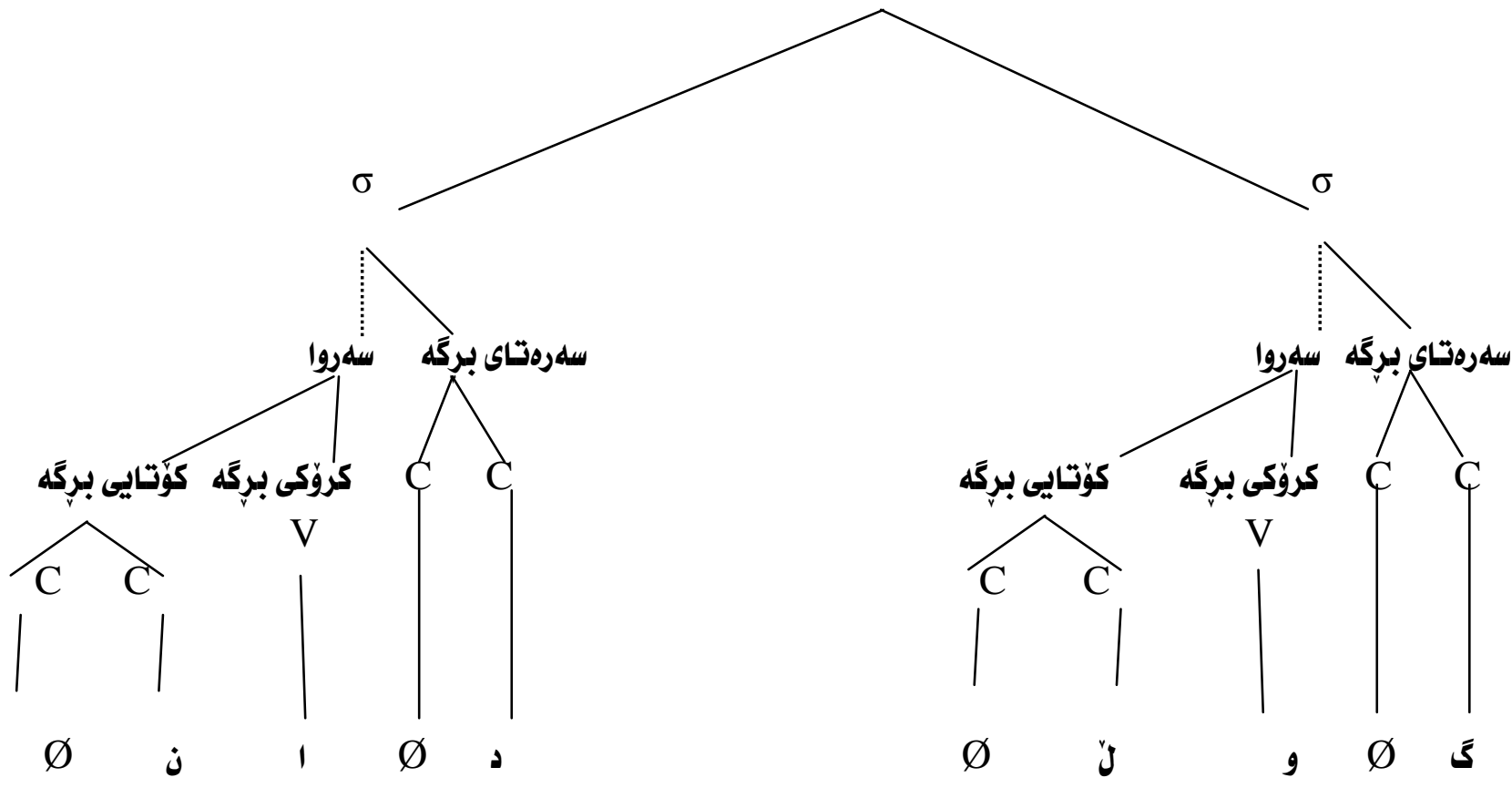

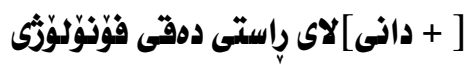

$$
\begin{aligned}
& \text { هيلّكارى زماره (7. . 1) } \\
& \text { نو اندنى دروستهى بر گِيى وشهى (كُولدّان) }
\end{aligned}
$$




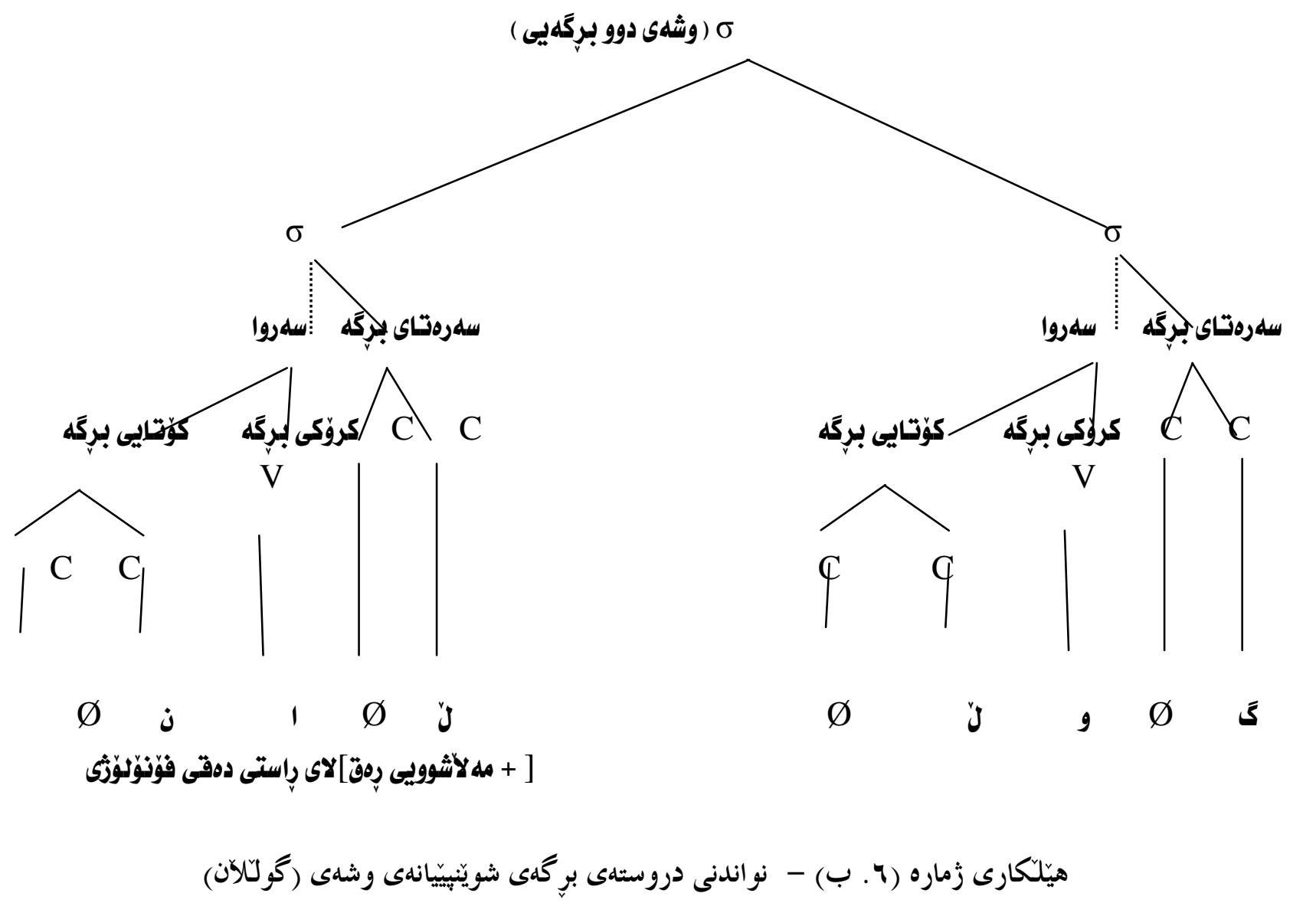

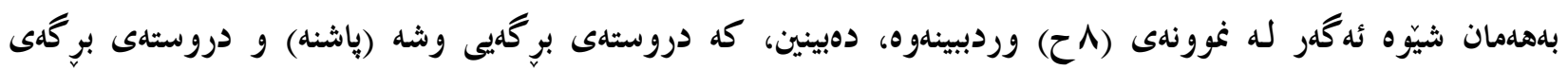

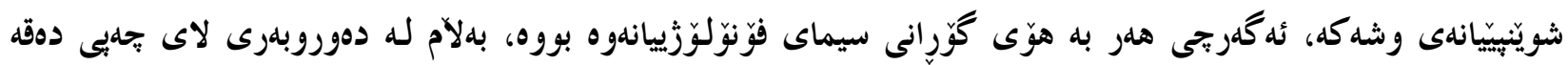

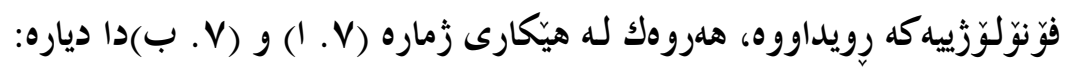




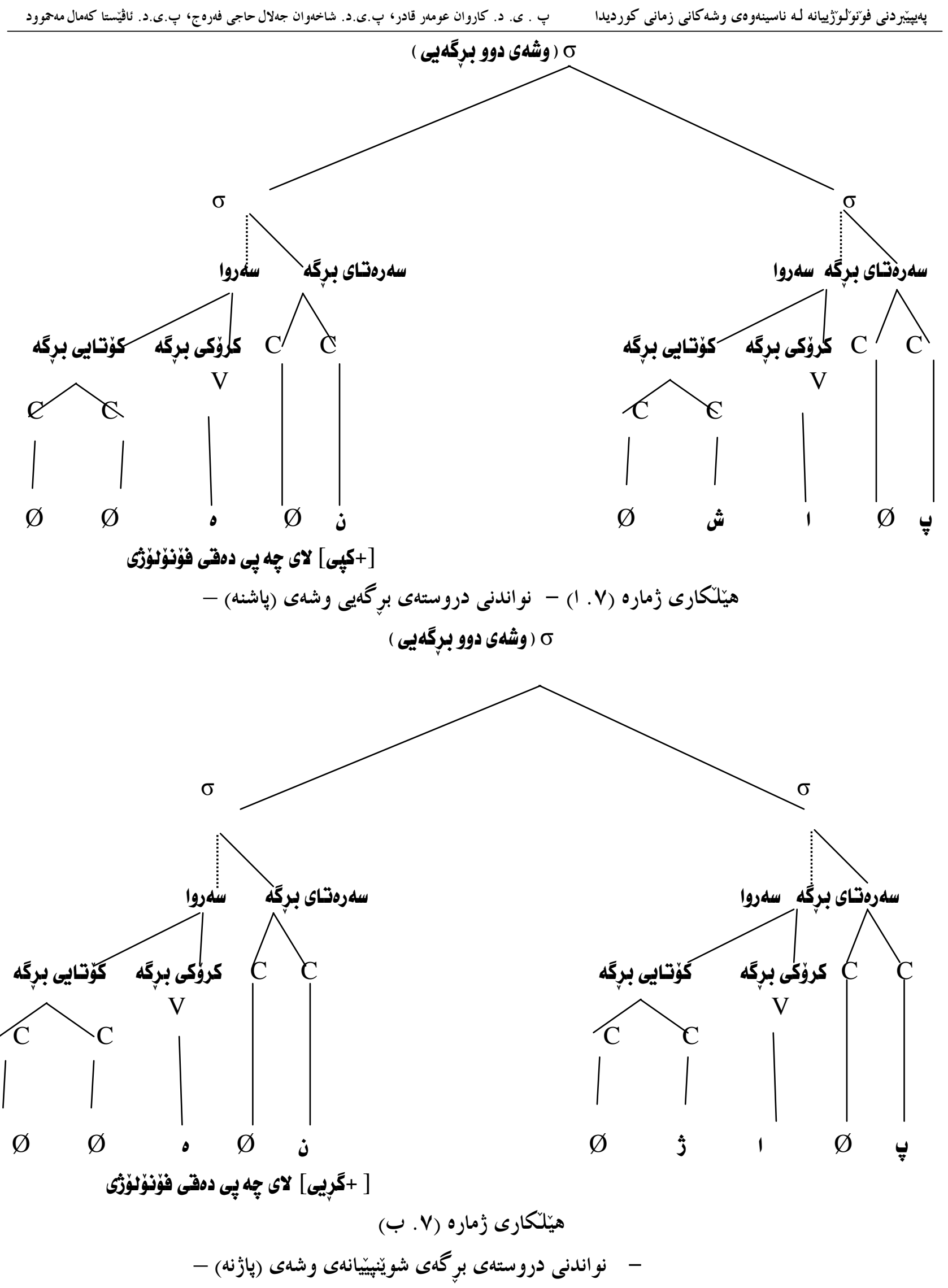




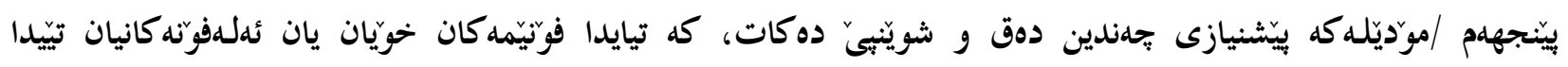

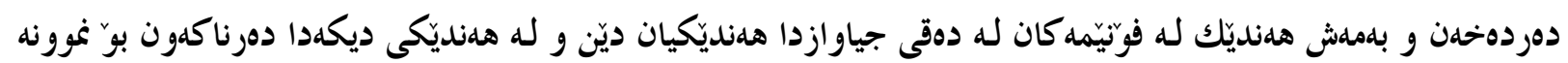

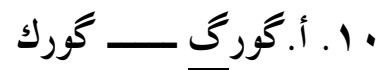

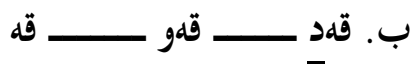

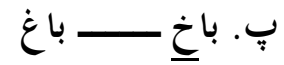

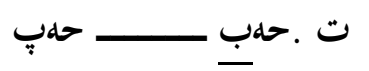

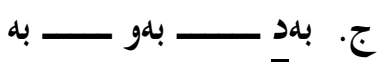

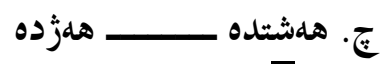

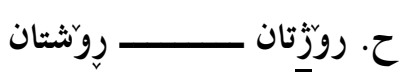

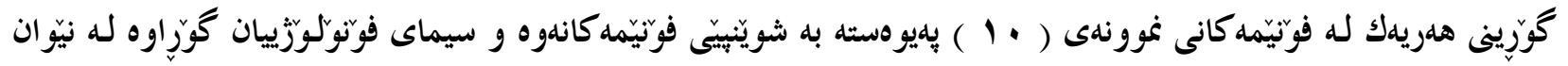

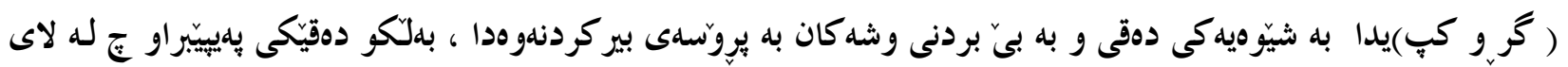

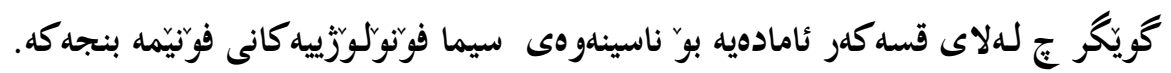

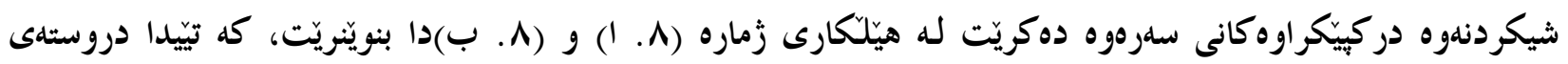

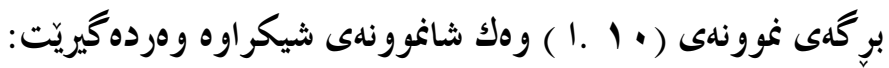

o

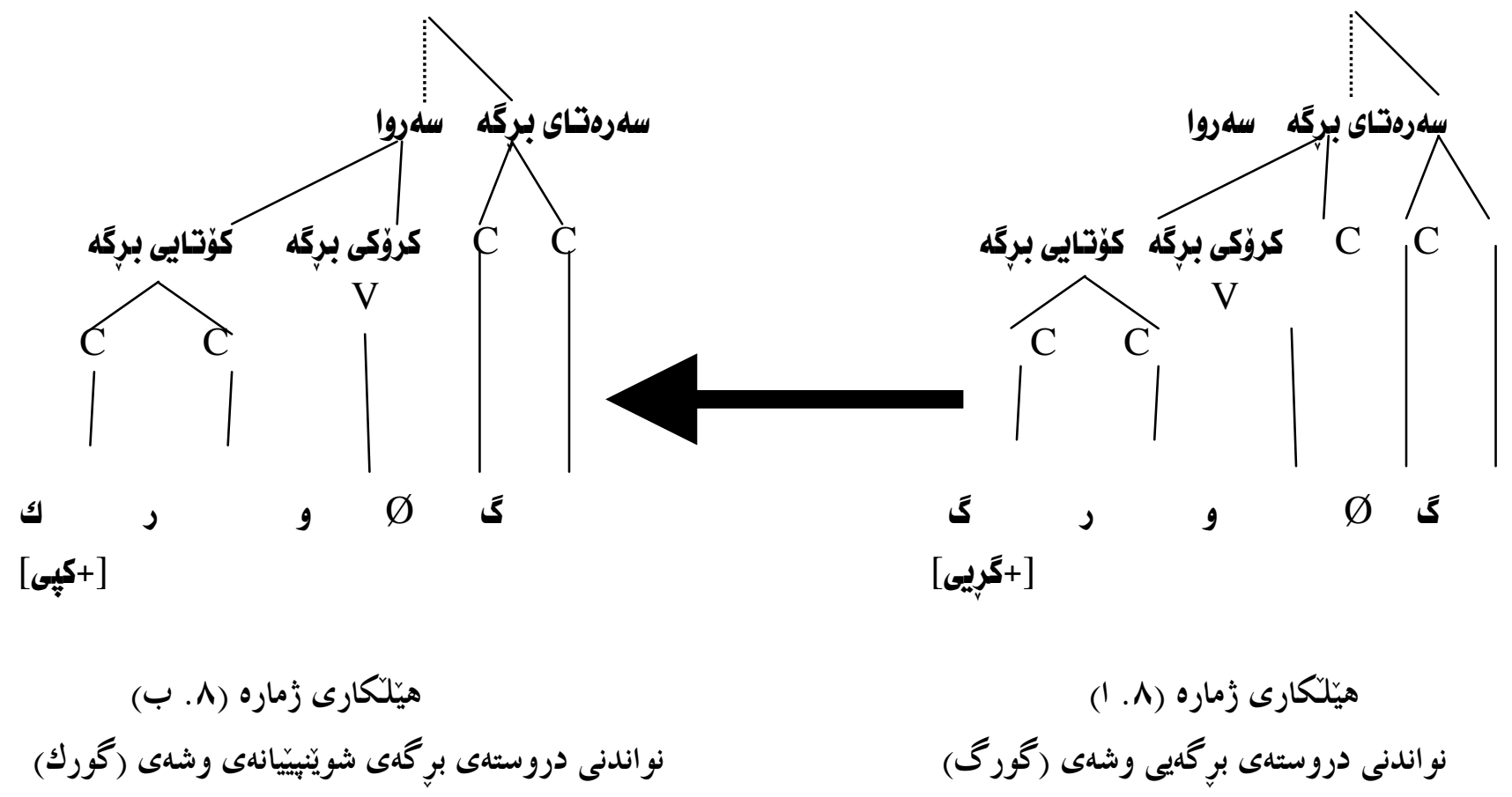




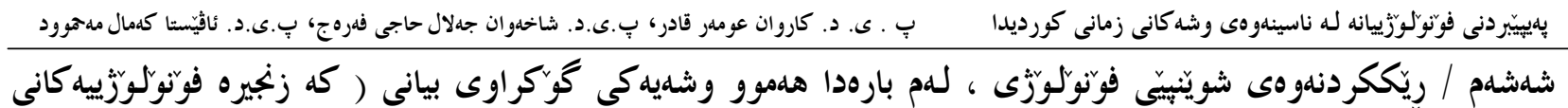

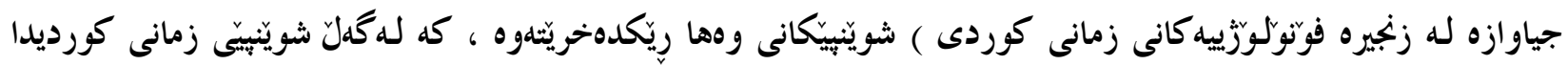

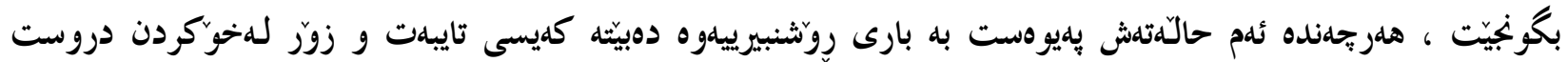

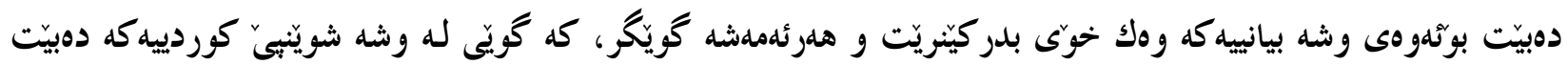

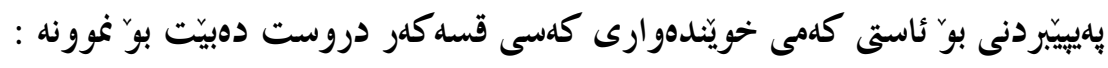

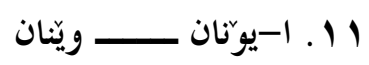

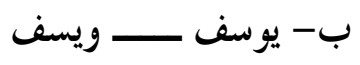

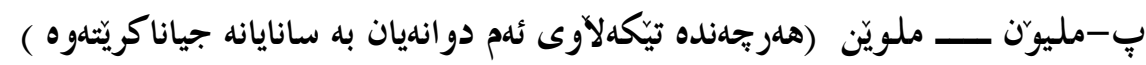

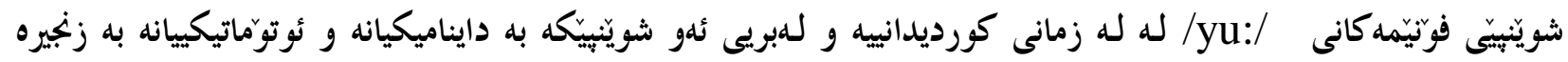

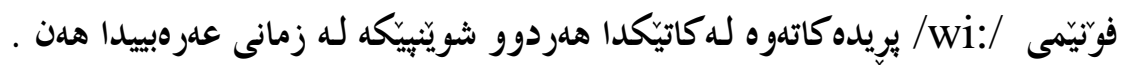

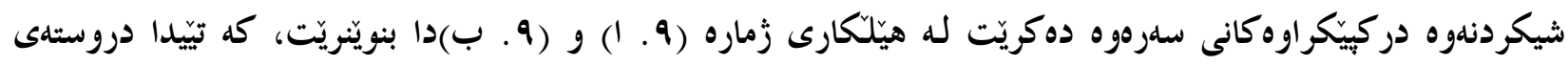

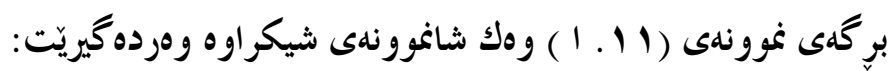

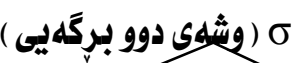

$\sigma$

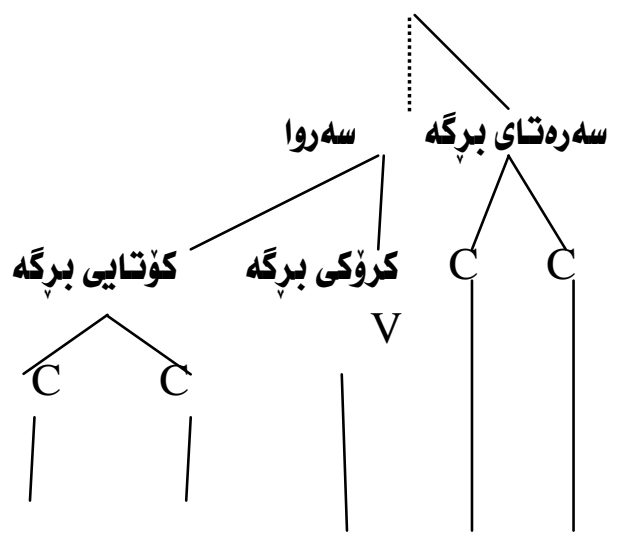

$\varnothing$

\begin{abstract}
$\dot{j}$
\end{abstract}
$\varnothing \quad$ ن

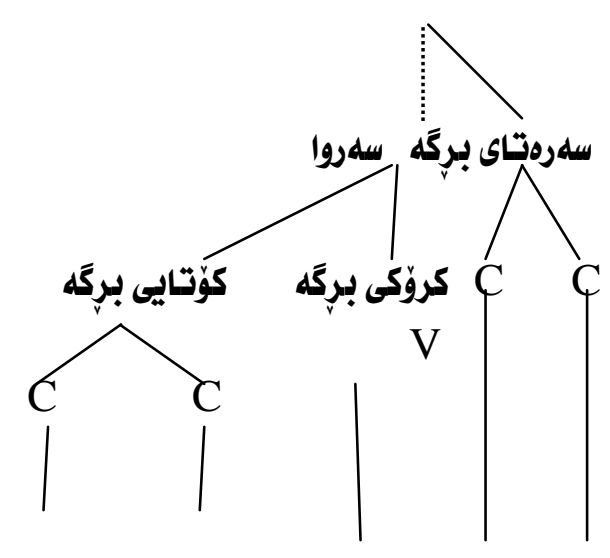

$\varnothing \quad \varnothing$

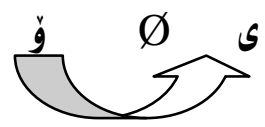

[ + دهت بيّكردنى برِّه به كوّنسنانت/نيمججمقاولى /ى/] هيلّكارى زماره (9 . 1 (1)

- نواندنى دروستهى بر گديى وشهى (يوّنان) - 


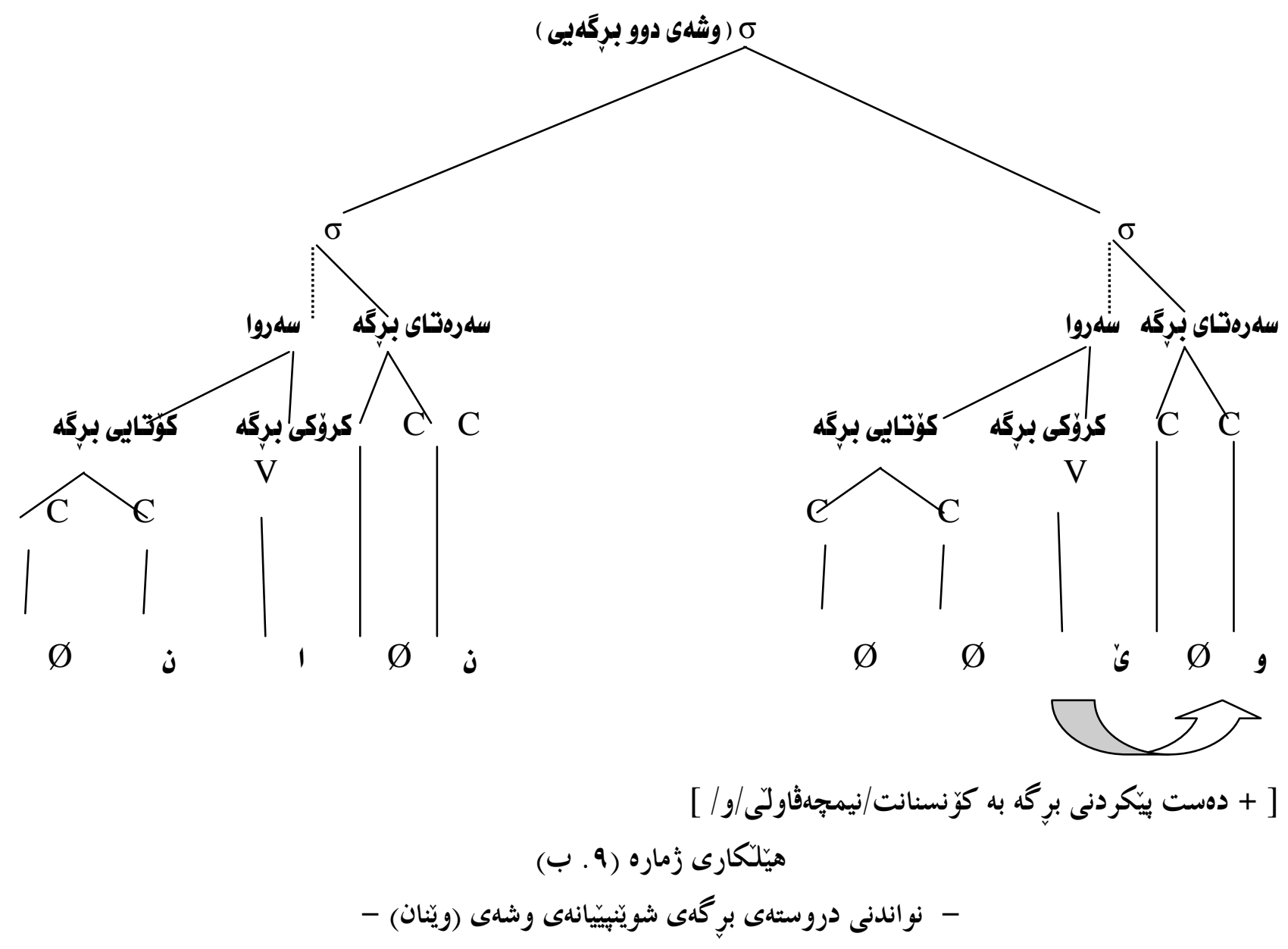

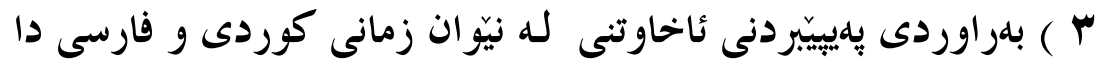

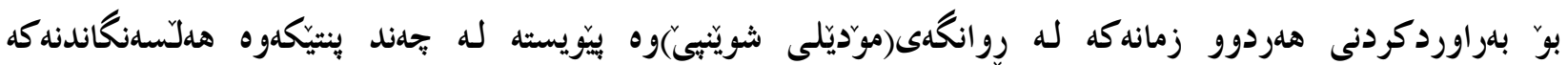

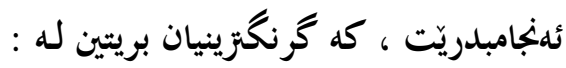

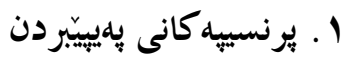

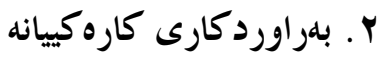

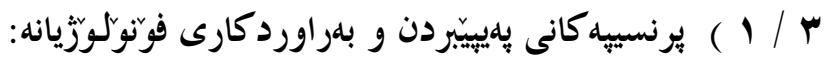

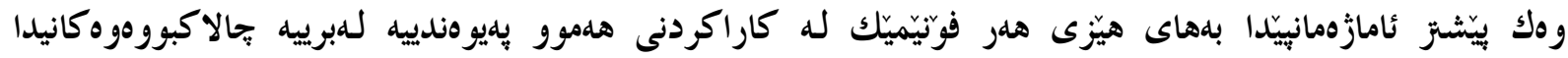

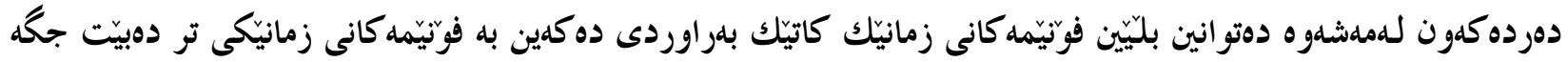

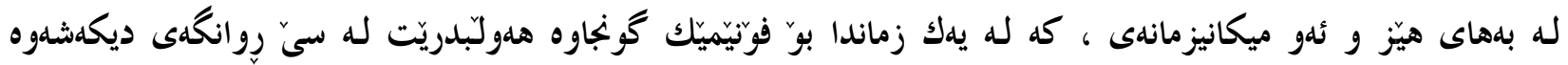

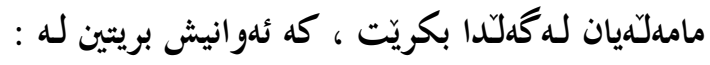




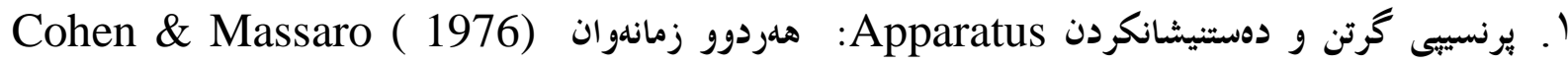

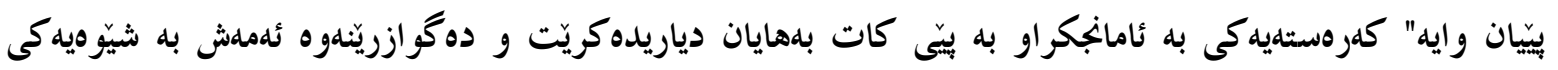

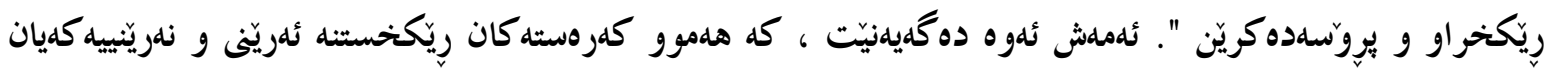

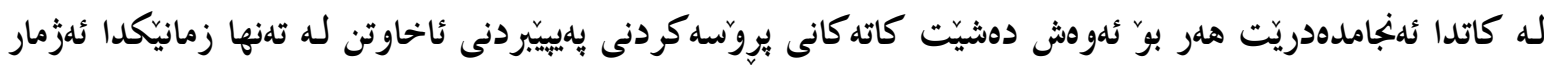

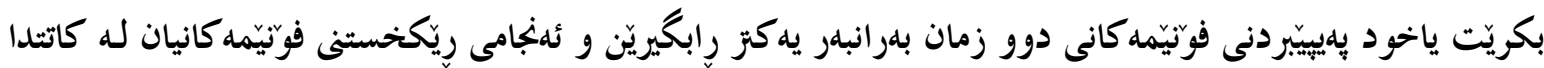

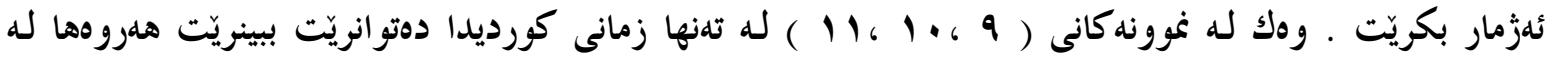

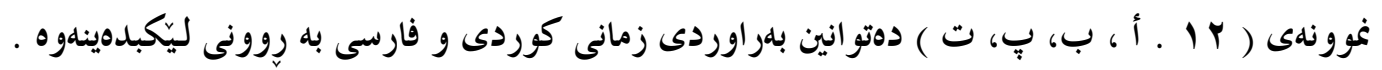

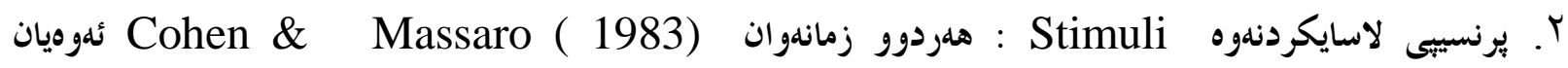

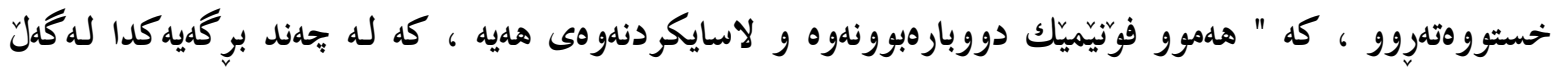

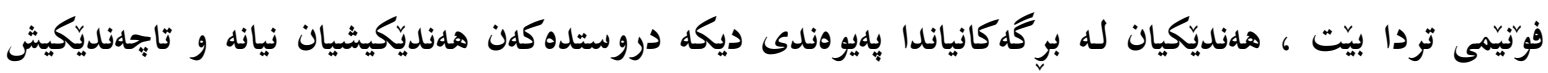

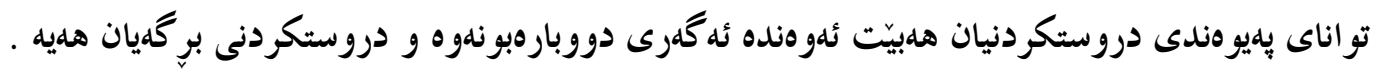

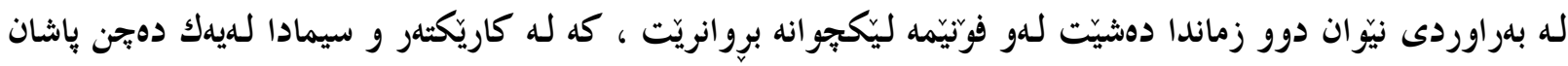

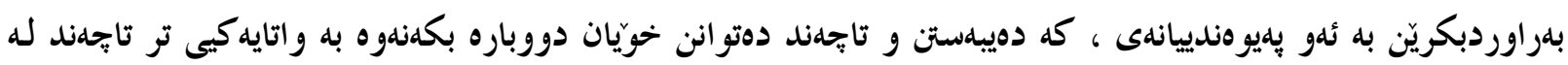

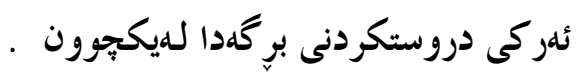

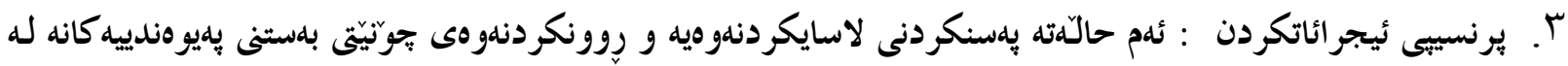

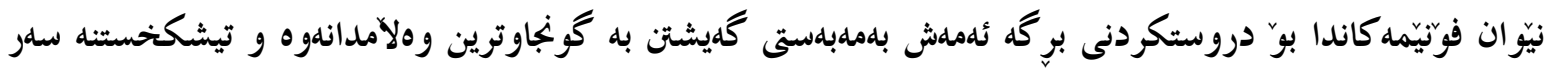

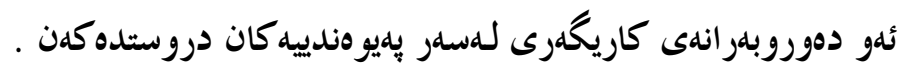

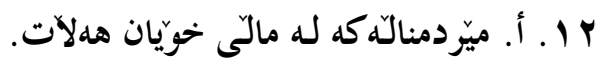

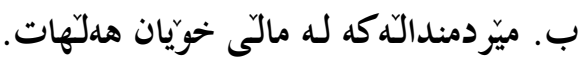
ب. ب. نقجوان أز خانهه فراركرد.

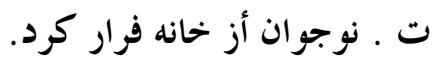

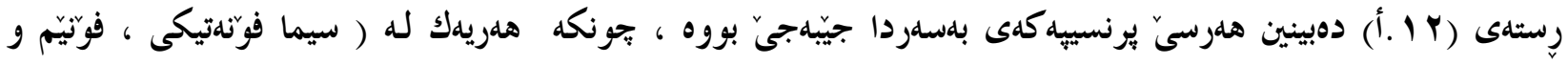

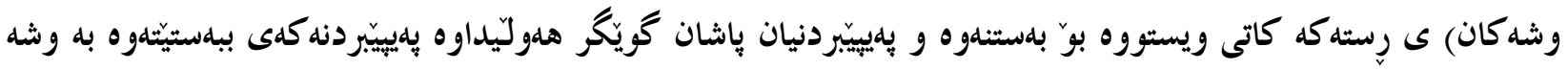

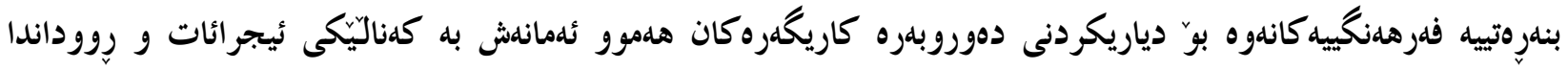

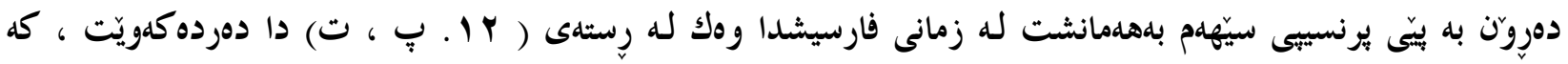

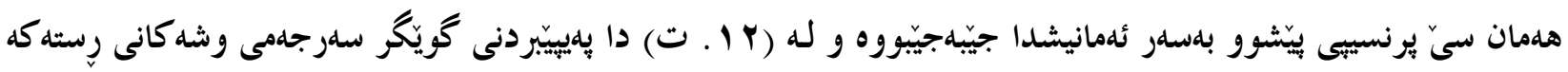

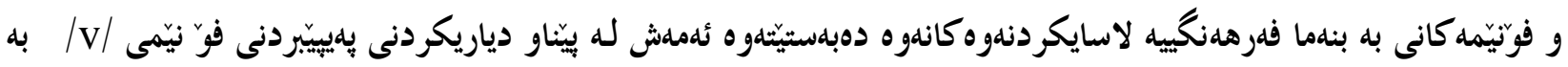

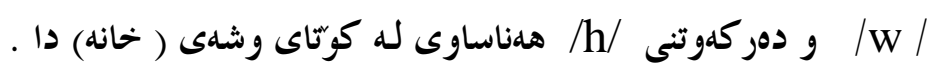

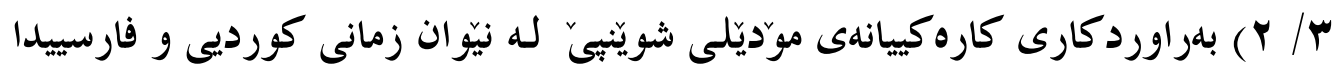




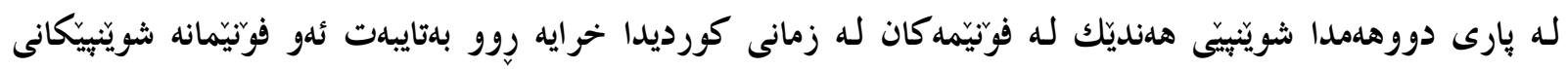

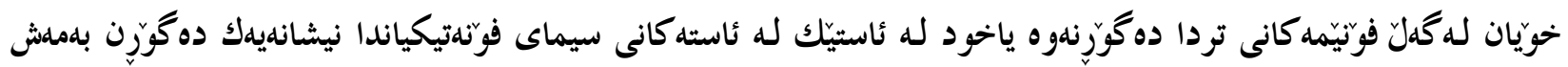

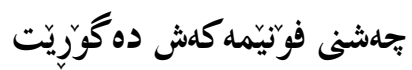

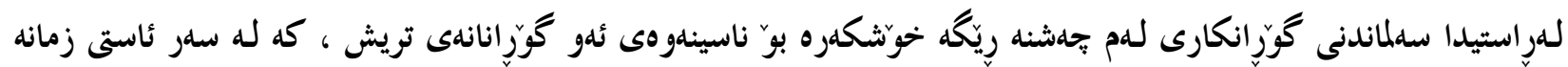

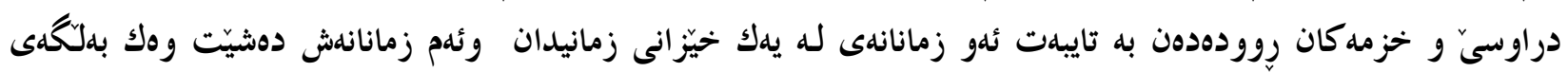

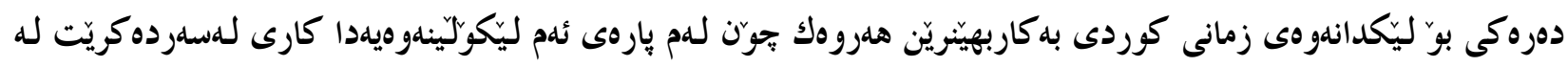

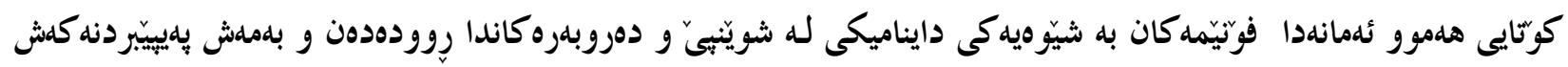

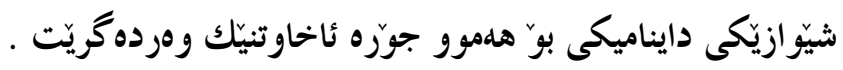

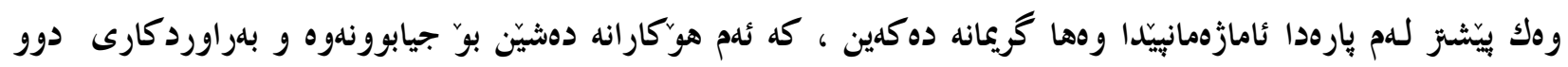

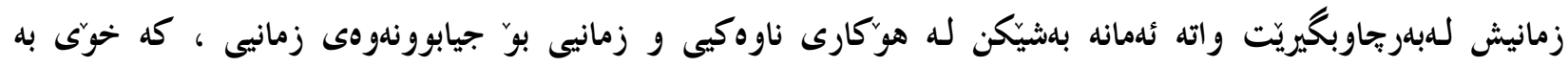

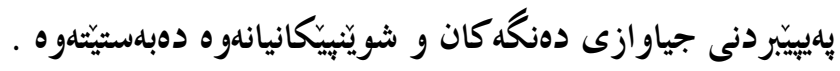

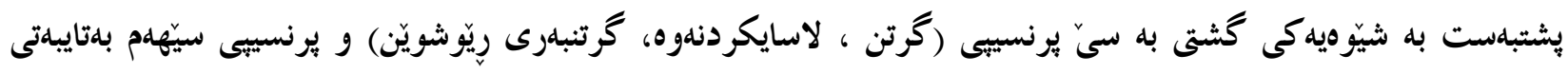

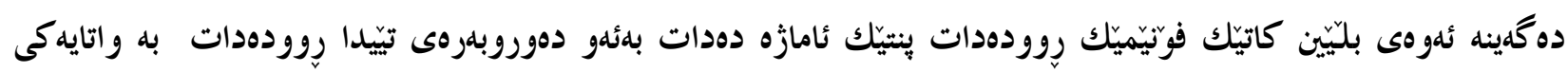

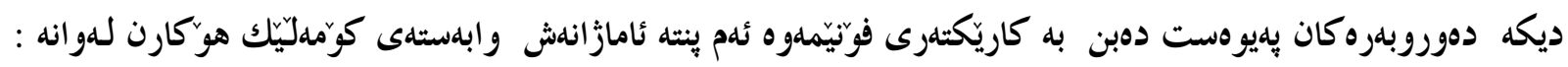

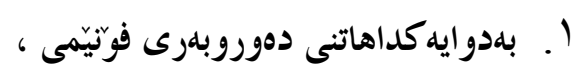

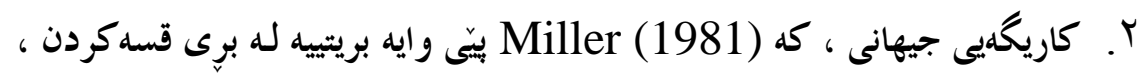

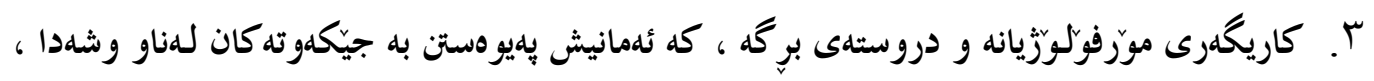

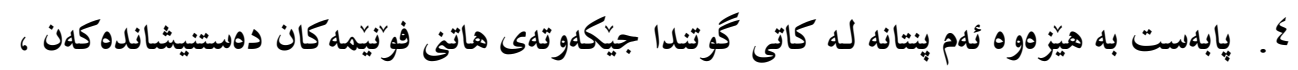

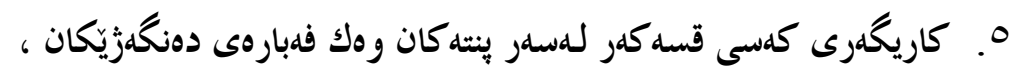

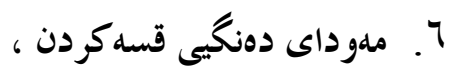

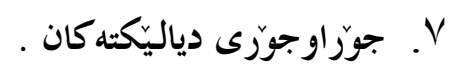

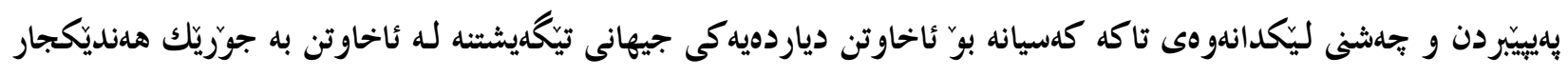

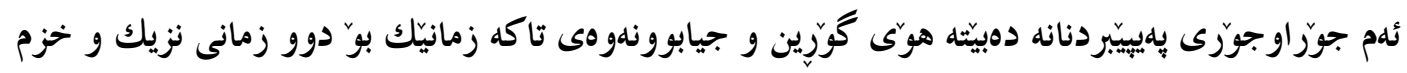

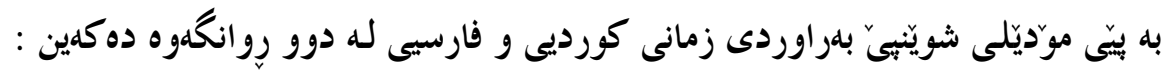

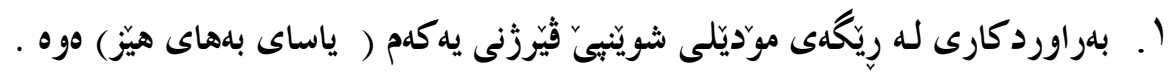

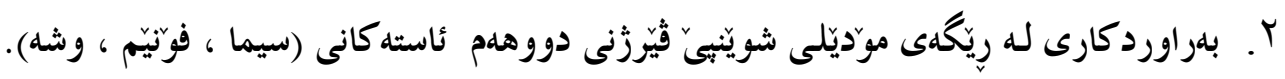

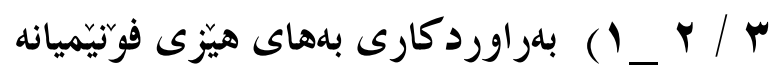

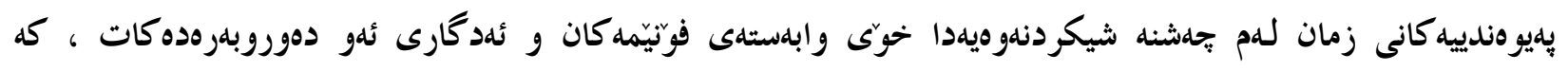

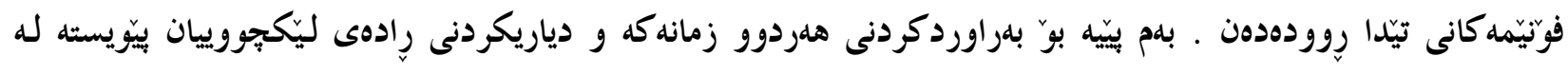




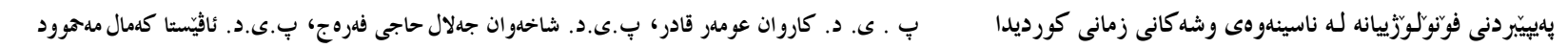

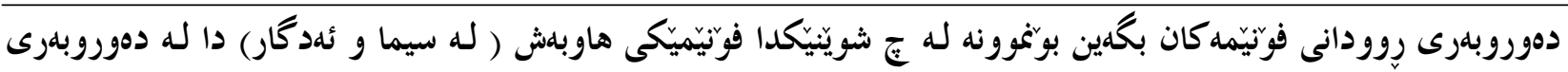

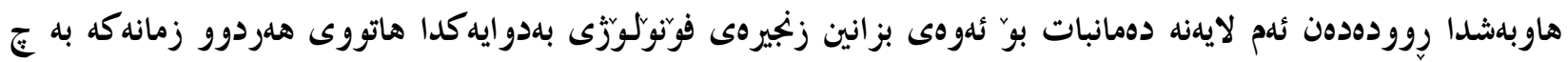

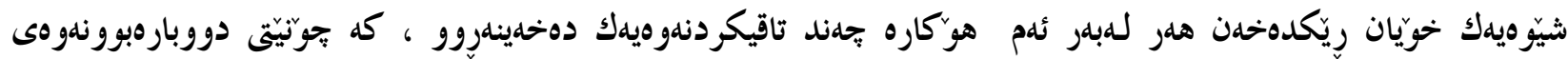

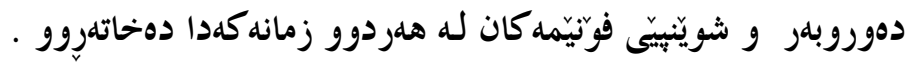
تاقيكردنهوهى فوَّيَّمى /t / لـه زمانى كورديد

\begin{tabular}{|c|c|c|c|c|c|c|c|c|}
\hline \multicolumn{2}{|c|}{ لهدواى //J/ } & \multicolumn{2}{|c|}{ ل لهدواى / / / } & \multicolumn{2}{|c|}{ له يِيّ /n /n } & \multicolumn{2}{|c|}{ لهيِش / ل ل } & \multirow{4}{*}{ 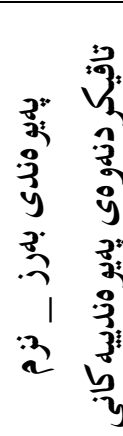 } \\
\hline دهرنه كهوتن & دهر كهوتن & دهرنه كهوتن & دهر كدو تن & دهرنه كهووتن & دهر كهوتن & دهرنه كهوتن & دهر كهوتن & \\
\hline كهمهيّزه له & بههيزّه له & كهمهيّزه لـه & بههيزّه له & بيَهْيَزه له & بههيزّه له & كذمهيزّه هله & بههيّزه & \\
\hline سينتاكسدا & 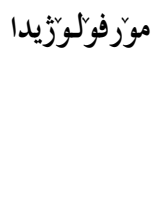 & سينتاكسدا & موزّرفولكوزَّيدا & سينتاكسدا & موَر فوَلكورَّيدا & مورَرفوَلوَّرَيدا & لهسينتا كسدا & \\
\hline
\end{tabular}

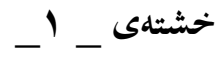

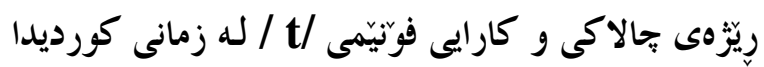

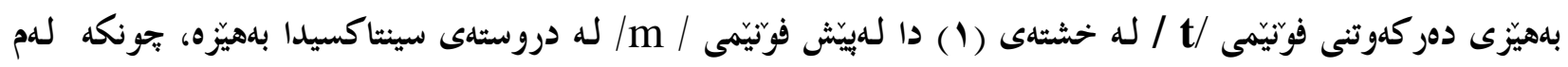

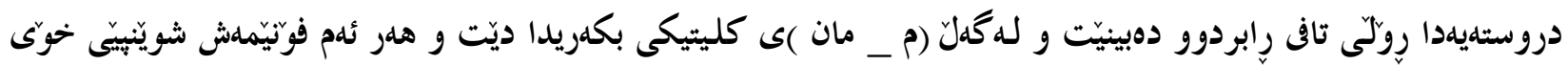

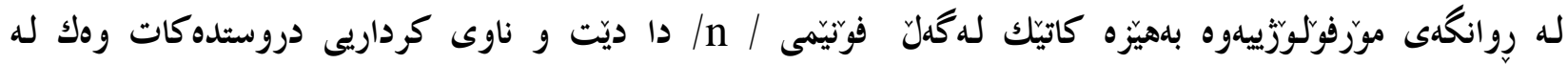

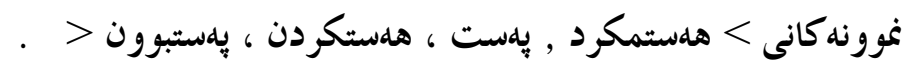

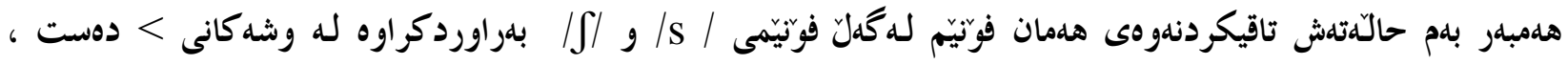

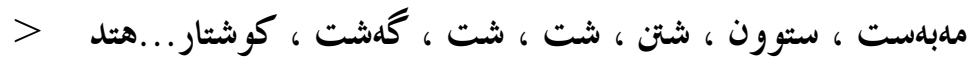

تاقيكردنهو هى فوتنيّمى /t / له زمانى كوردى و فارسيدا

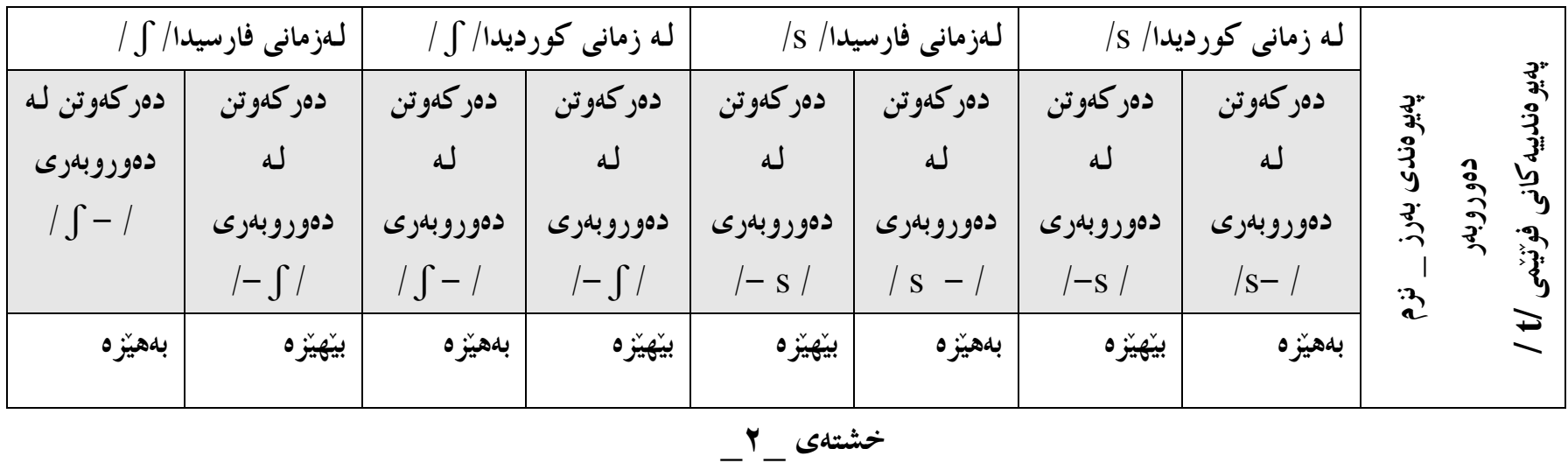

بهراوردى دهوروبهرى فوَنيّمى له نيّوان زمانى كوردى و فارسى 


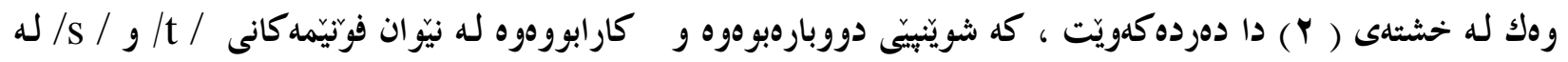

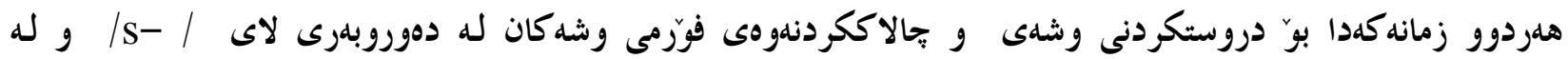

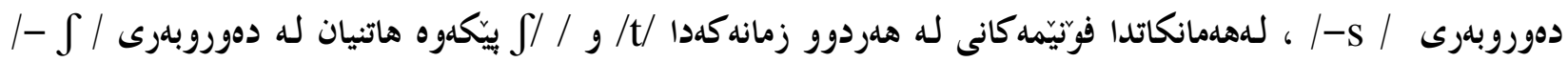

$$
\text { لاوازه و له / - ك / بلهيّزه . }
$$

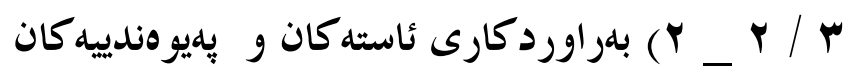

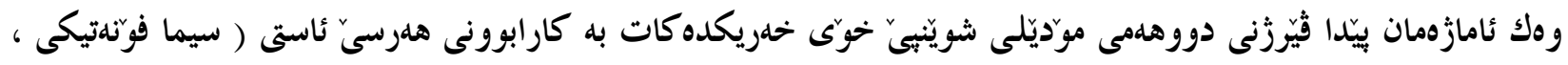

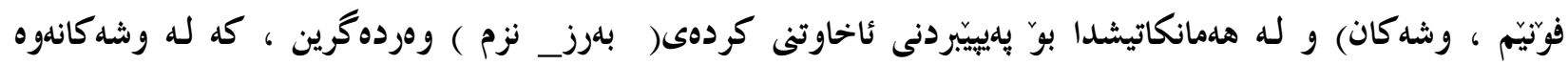

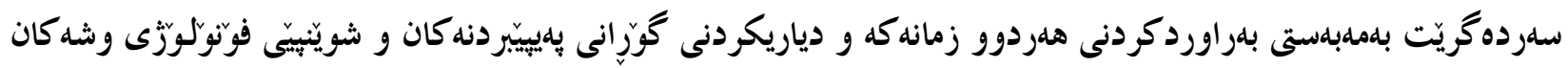

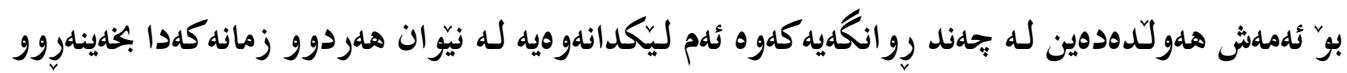
ا ـ بلهراوردكارى و كاراكردنى ئاسته كان : للهم تيّروانينها ملبهست للهو وشانهيه ، كه لله هلردوو زمانه كهدا يهك

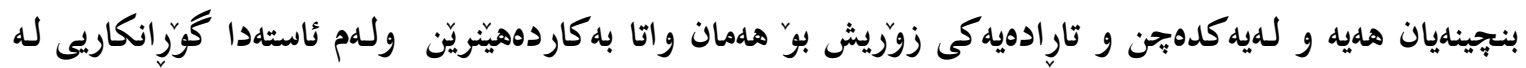

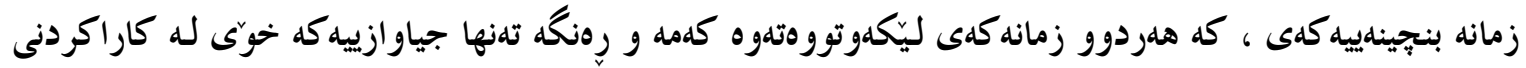

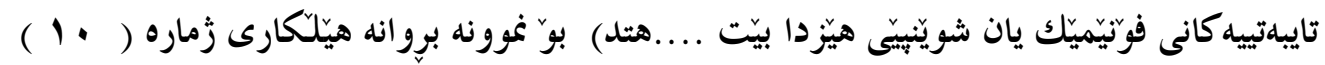

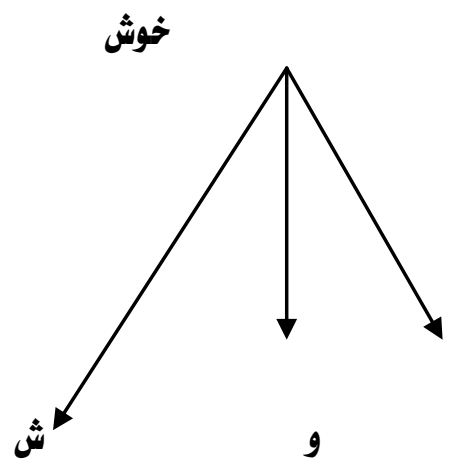

$\dot{\tau}$

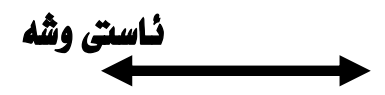

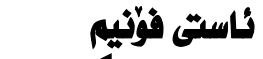

ثاستى سيما فوّنفتيكييه كان

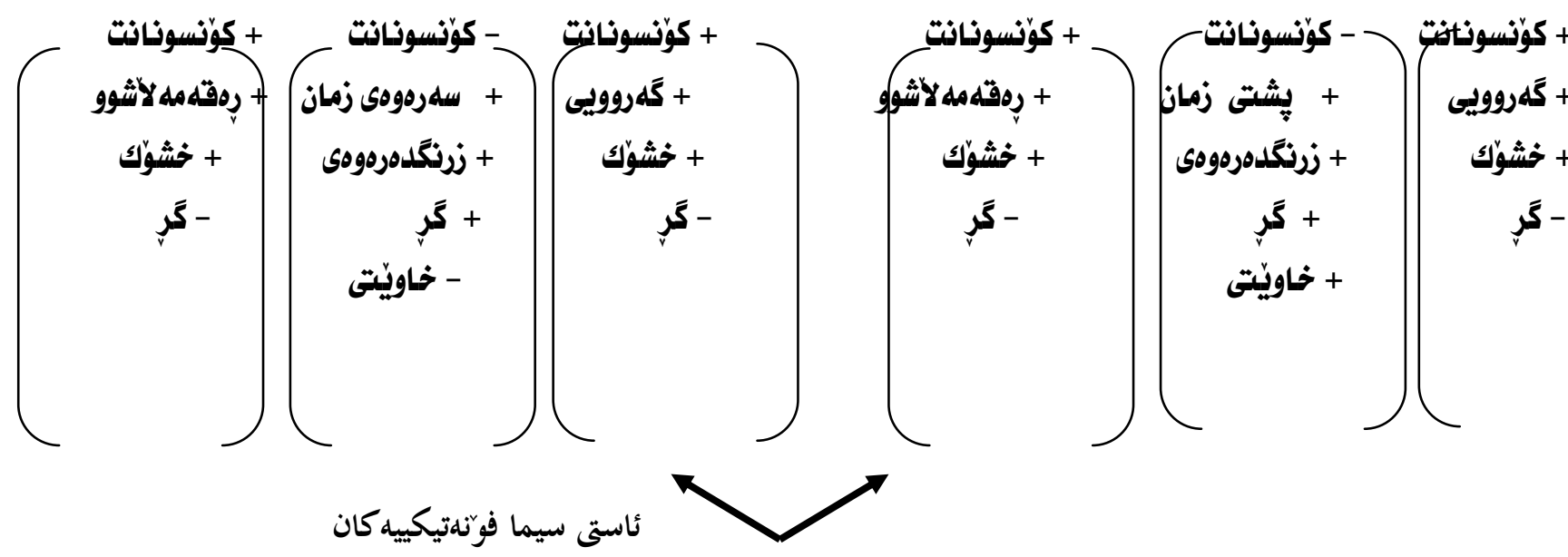

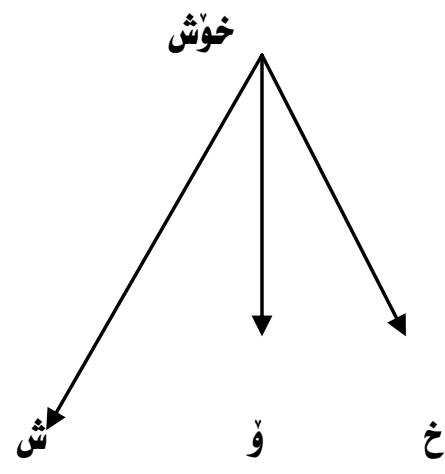

$\dot{\tau}$ 


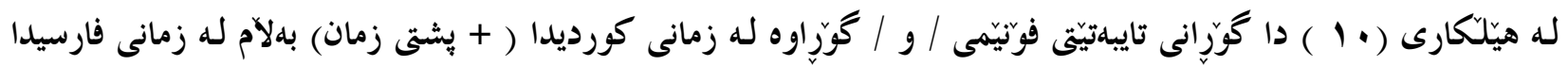

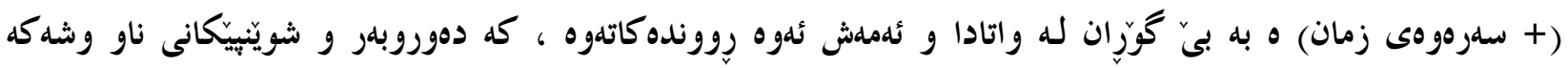

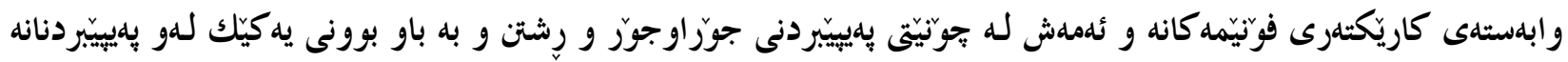

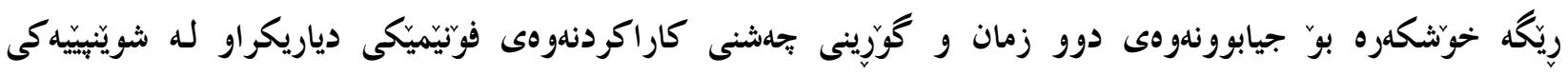
دياريكر اودا .

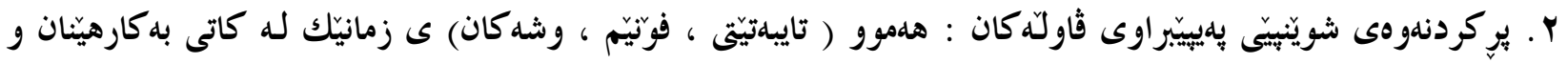

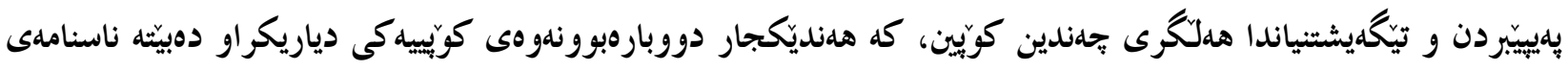

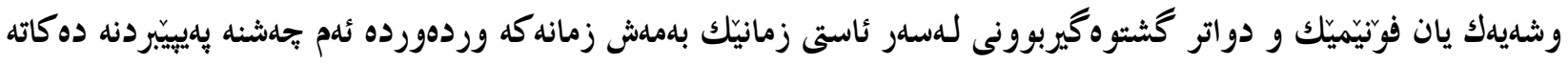

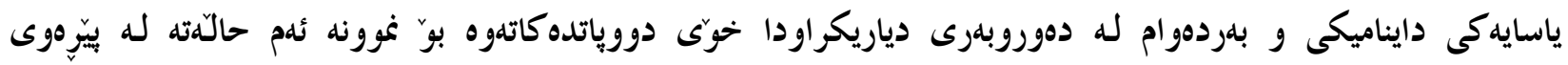

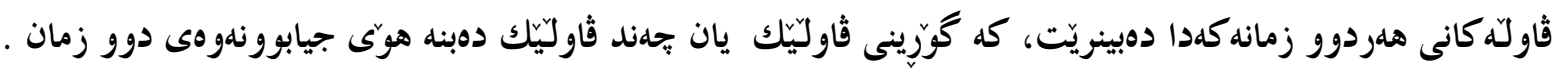

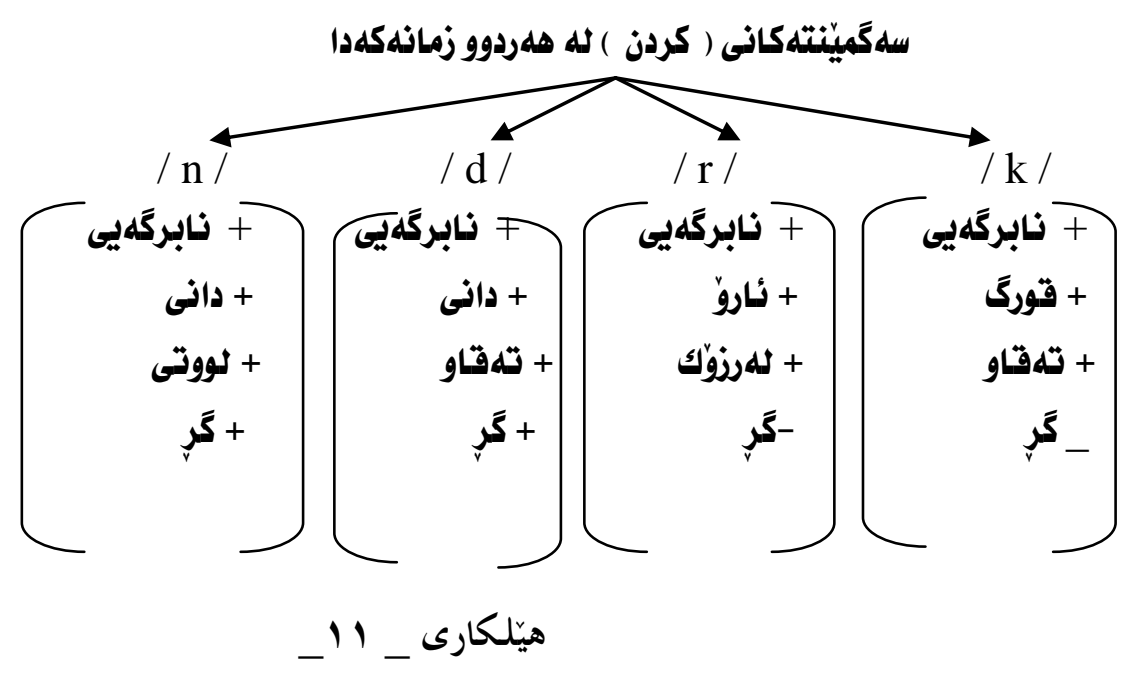



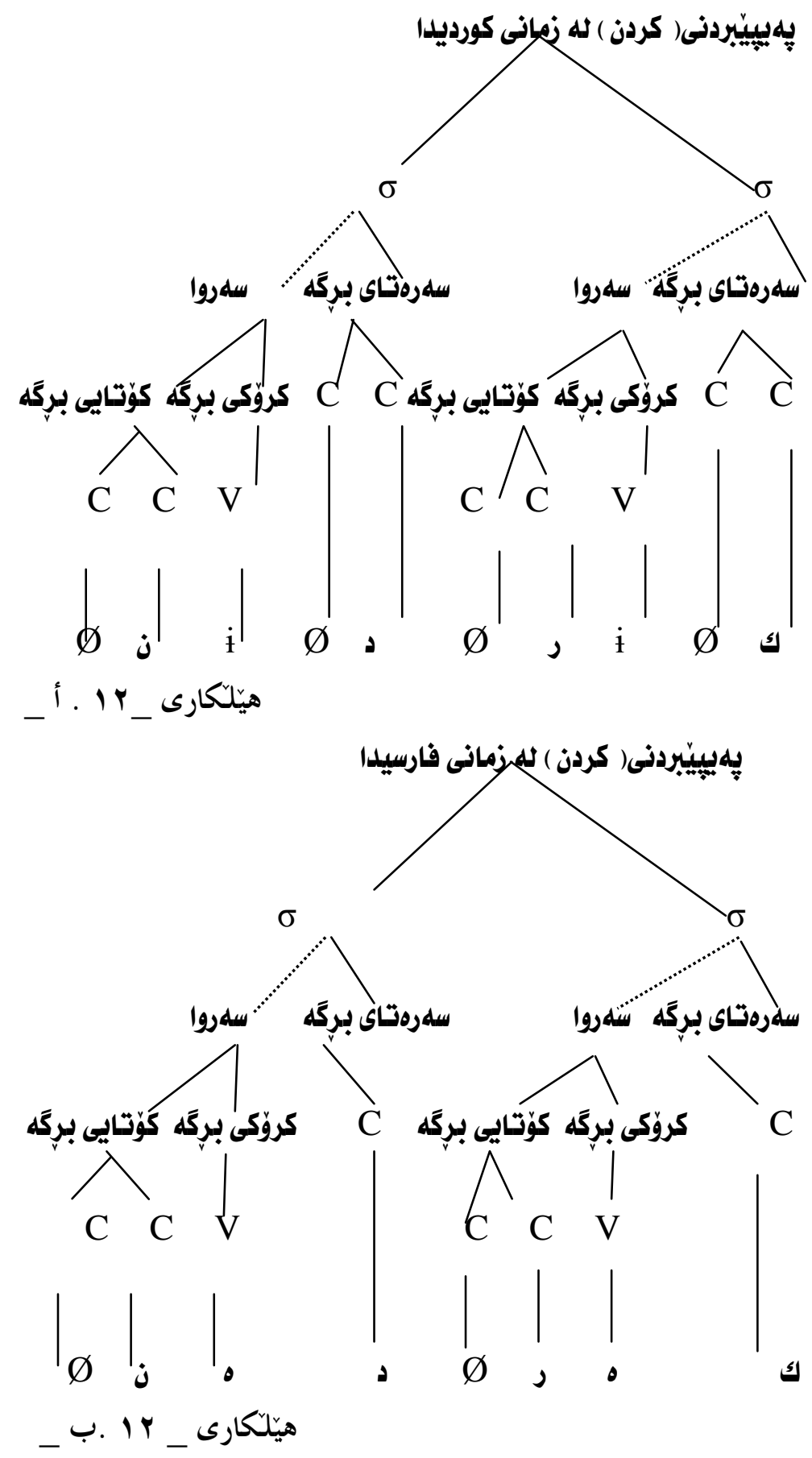

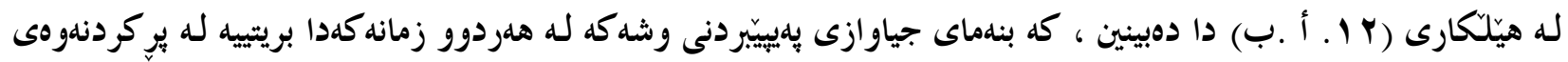

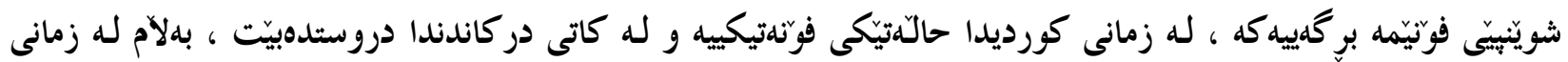

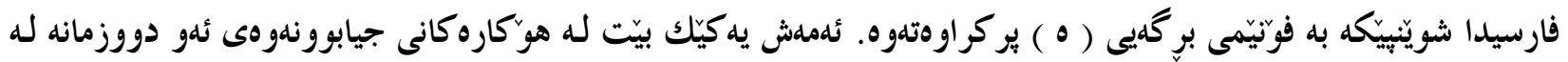

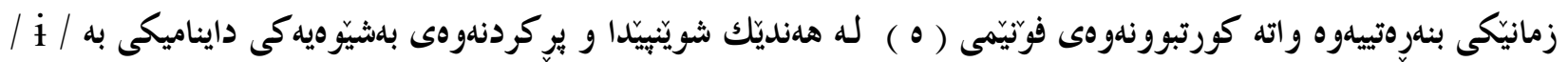




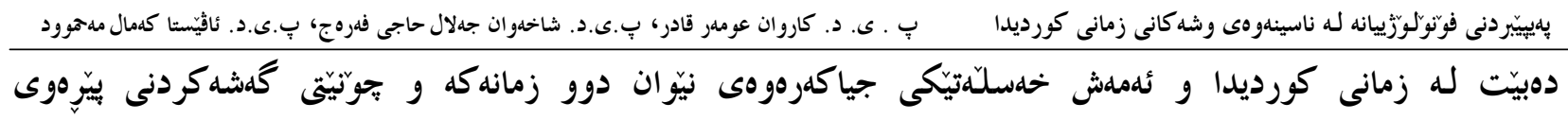

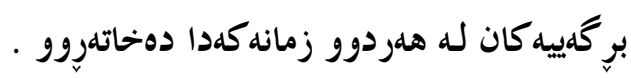

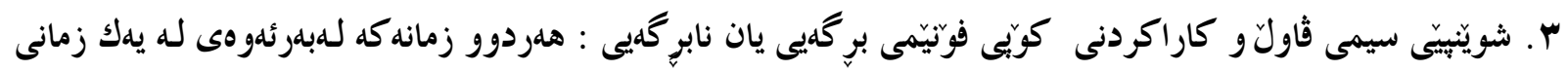

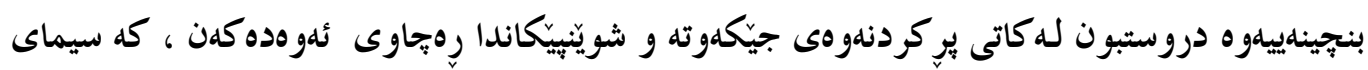

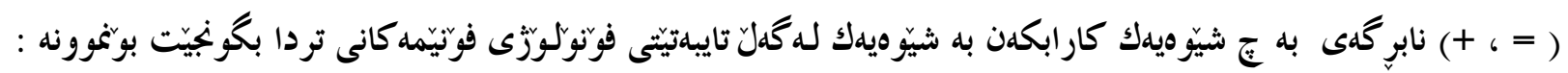
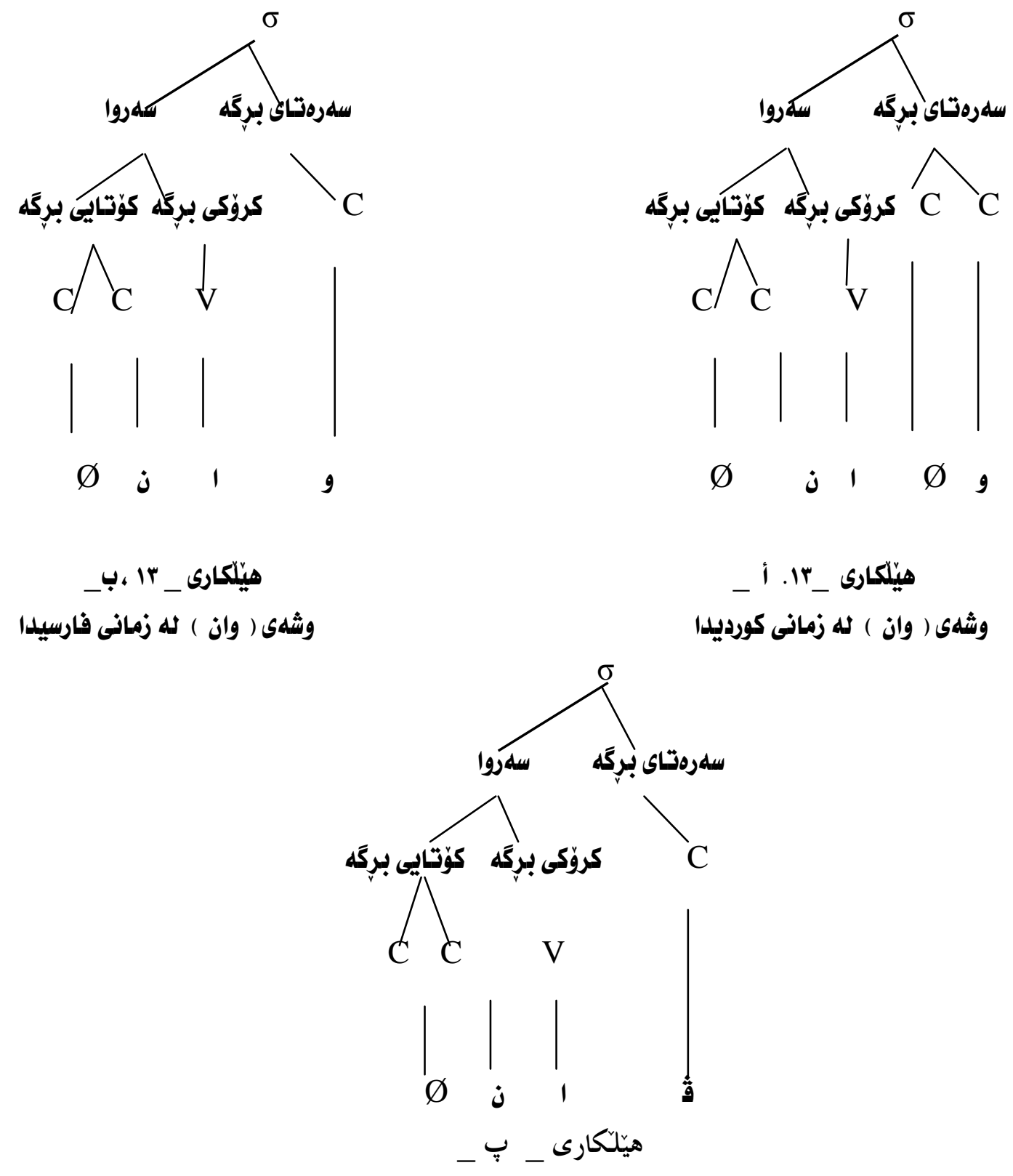

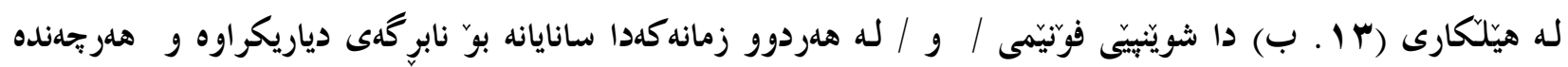

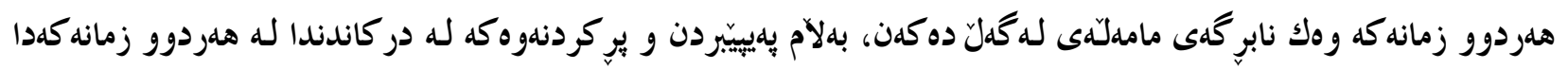

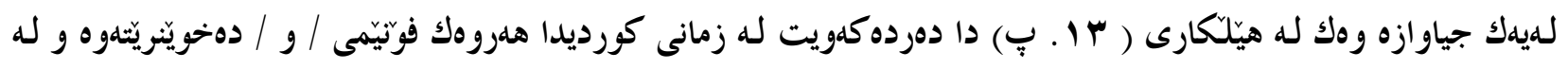

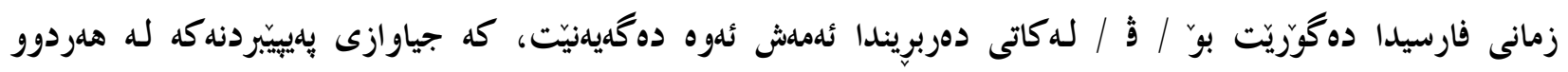




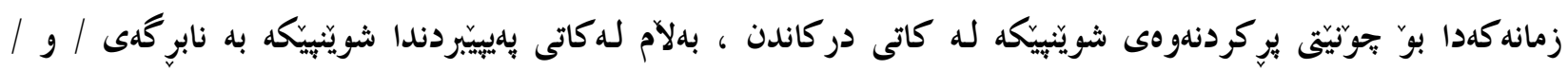

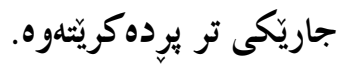

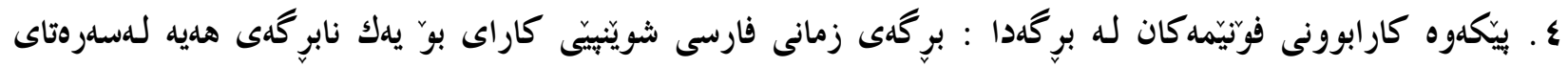

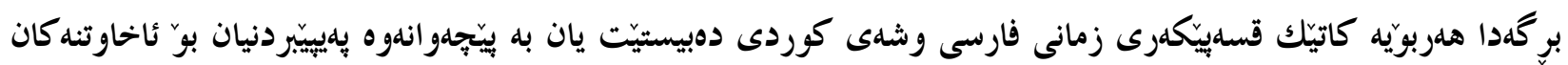

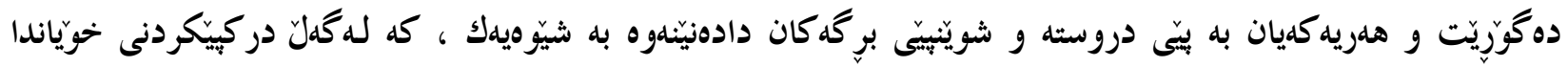

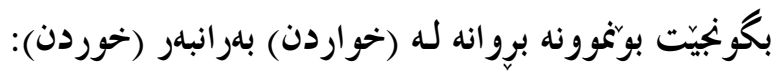

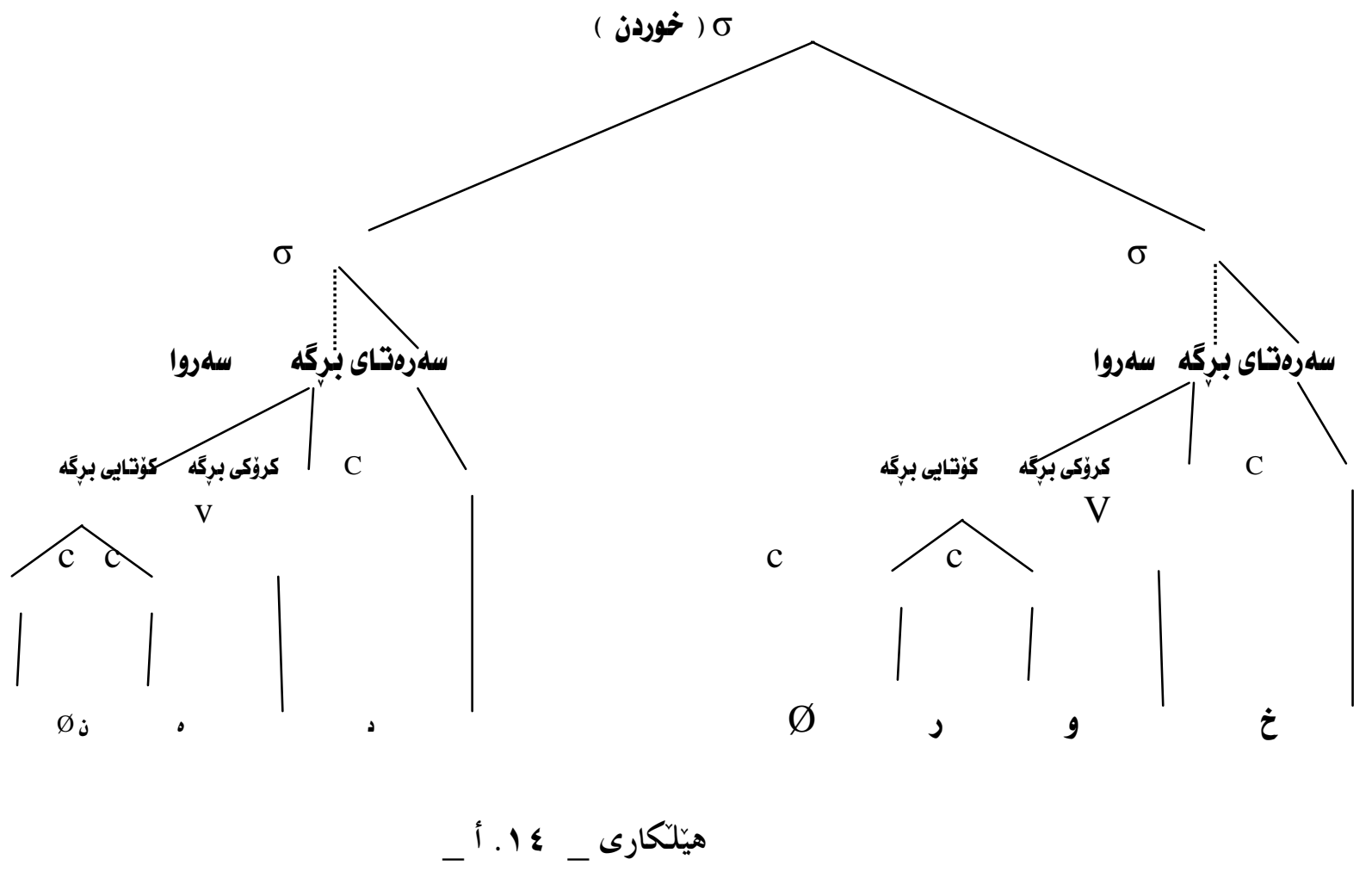




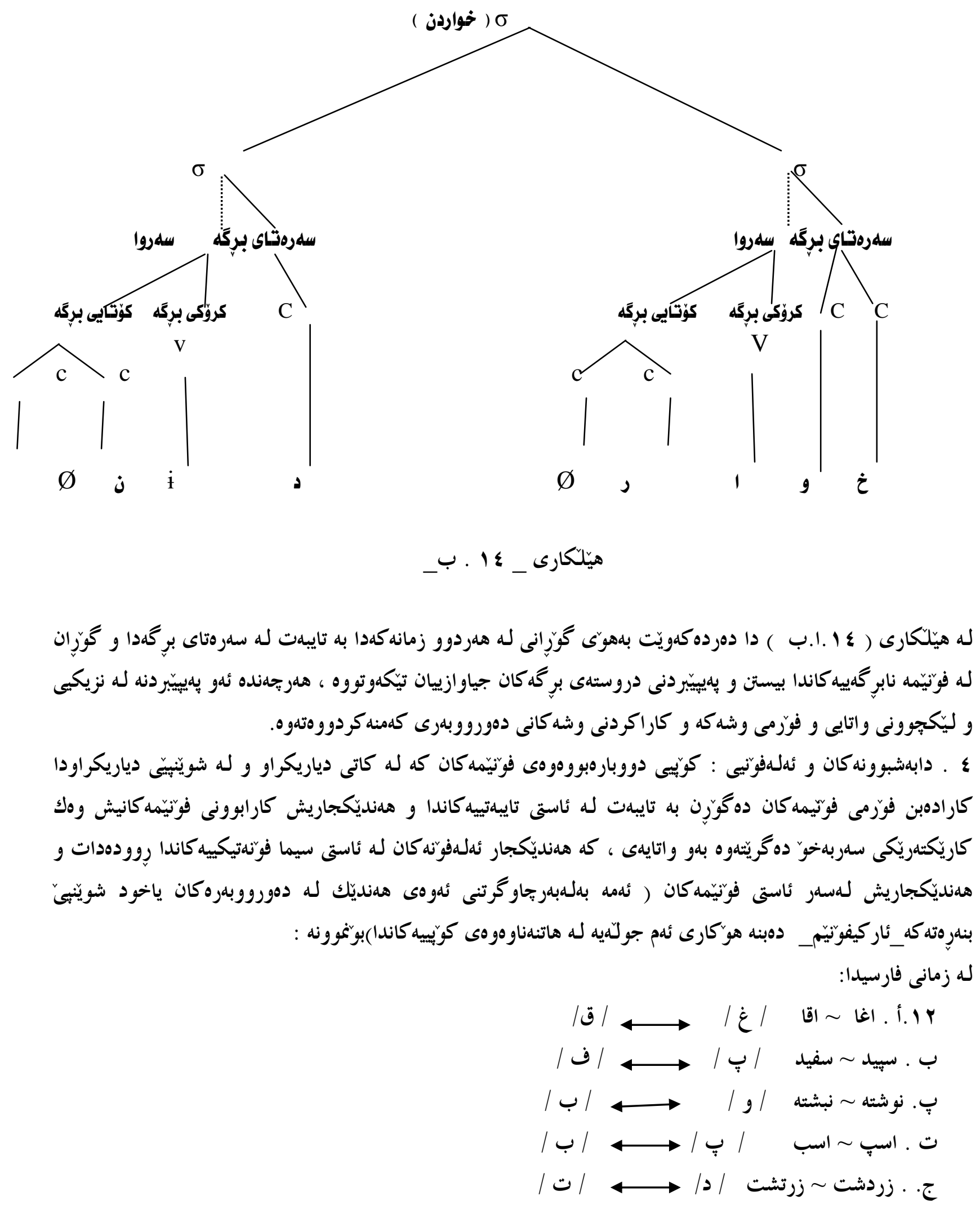




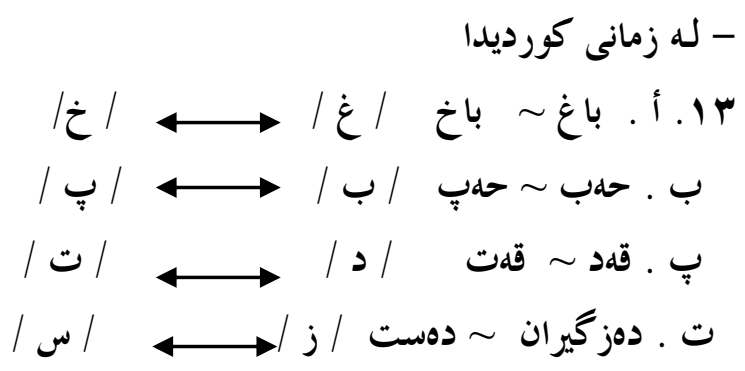

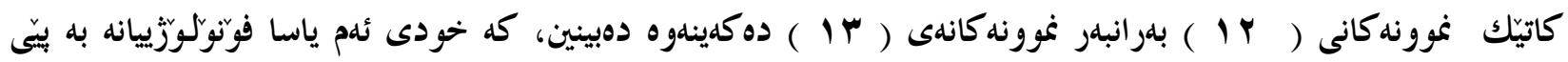

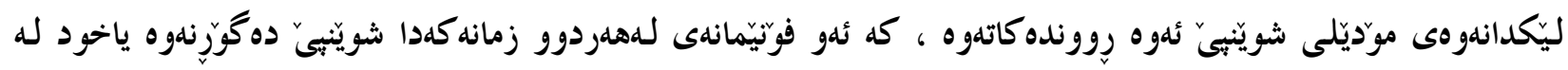

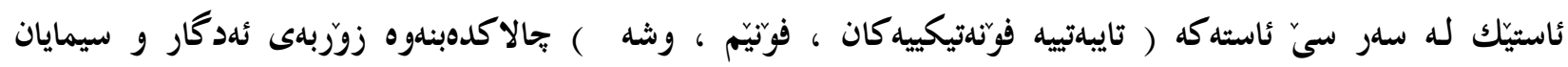

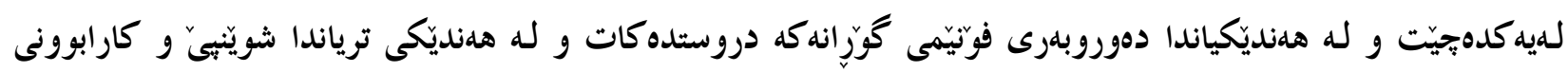
بيليو هندييه فوَّنيّمييل كان دروستى ده كهن .

نٔنجام

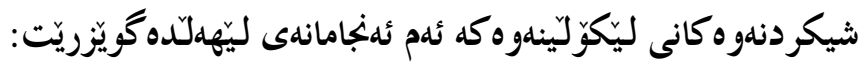

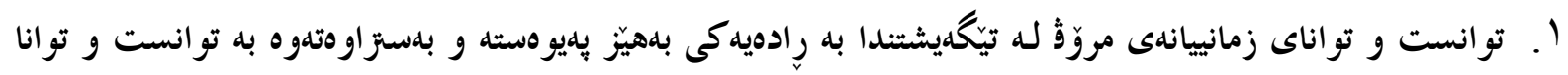

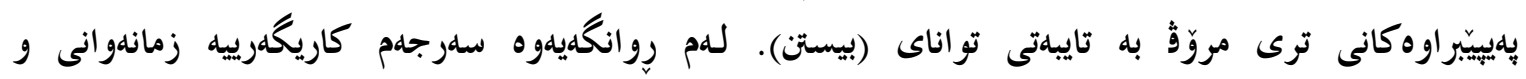

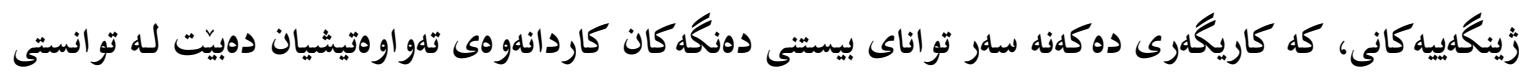

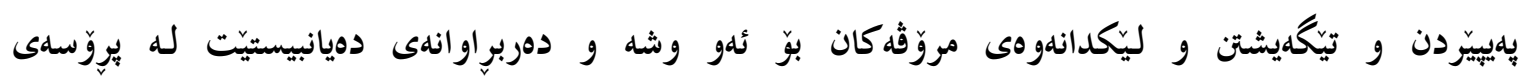

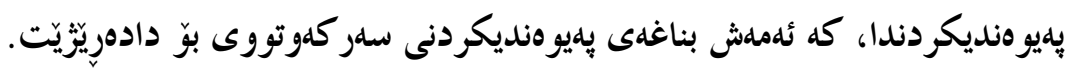

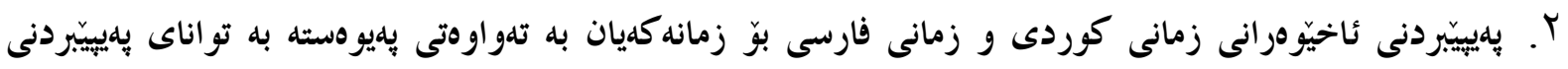

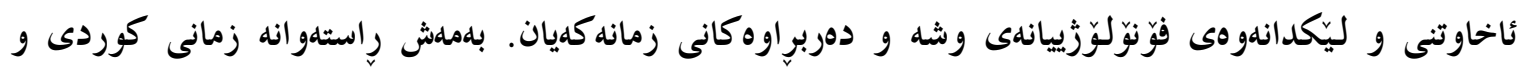

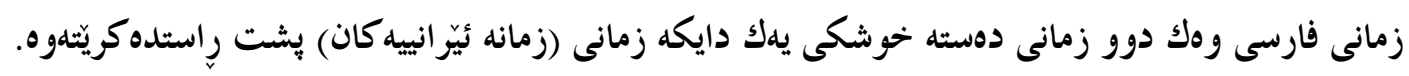

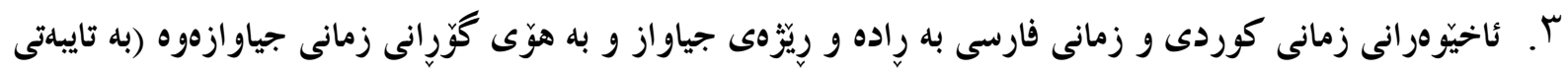

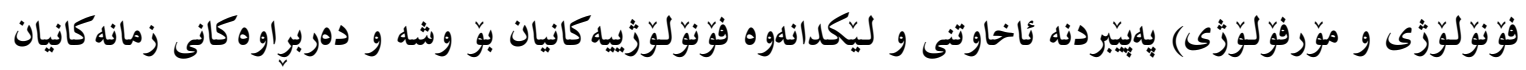

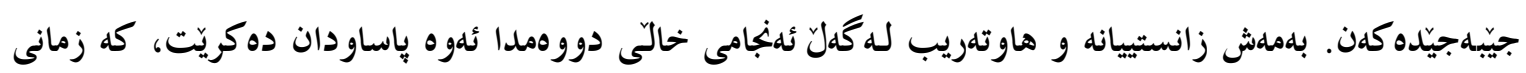

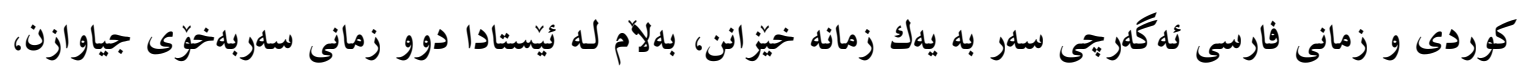

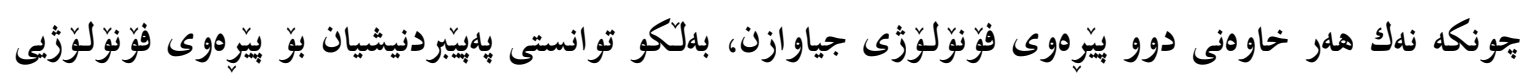
زمانه كهيان جياوازه. 


\section{سلر جاوهكان}

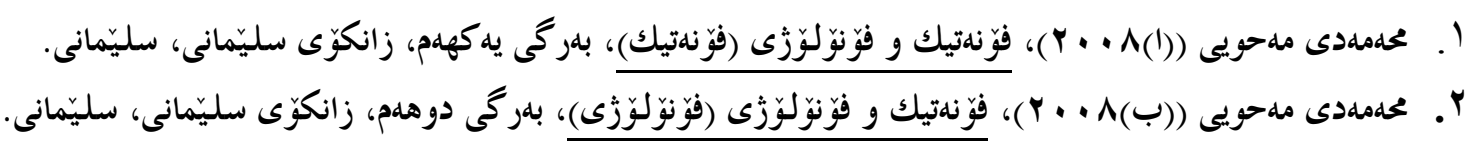

3. Cairns, P., R.Shillcock, and J. Levy .1995.Bottom - up connectionist modeling of speech. In Connectionist Model of Memory and Language, (J.P.Levy pp. 289-310., D, Bairaktaris \&others ed). London : UCL Press ,

4. Christiansen, M.H and N. Chater .2001. Connectionist psycholinguistics, Trends in CogSci, 5. 82- 88

5. Elman, J. L and J, L. McClleland. 1988. Cognitive penetration of mechanisms of perception : Compensation for co articulation of lexically restored phonemes. J. Mem. \& Lang, 27. 143 - 165.

6. Ganong, W, F, 1980. Phonetic categorization in auditory word perception, J. Exp Psych: HPP. 6, 110-125.

7. Hoffman, D.D. (2009). The interface theory of perception (Dickinson, S.Tarr, M., Leonardis, A \& others. Object categorization: Computer and human vision perspective. Cambridge University Press

8. Marslen - Welson, W\& Warren, P. (1994). Level of perceptual representation and process in lexical access: Words, phonemes and features, psychological review. 101. 653-675.

9. Marso, D.W. 1989. Testing between the TRACE model and the fuzzy logical model of speech perception. Cognitive psychology. 21.398-421.

10. McClelland, J.L and J, L. Elman. 1986. The TRACE model of speech perception, Cog. psych. 18. 1- 86.

11. Norris, D .1993. Bottom - up connectionist model of "inter action 'In Cognitive models of speech processing (G.T. M. Altman \& other). Hillsdale, NJ: Erlbaum, pp. 211-234. 